\begin{abstract}
Costello, Theresa Mary. Risk Factors for a Farm Vehicle Public Road Crash. (Under the direction of Roger Mitchell)

Although farm vehicle public road crashes are relatively infrequent events, they are more likely to result in injury and fatality than non-farm vehicle crashes. Farmers are concerned about their safety when driving farm vehicles on public roads, yet research attention to the issue is lacking. Drawing on transportation crash prevention models, this study posited that a combination of driver, vehicle, farm and public road environmental characteristics are associated with farm vehicle public road crash group membership.
\end{abstract}

A case-control study compared farms reporting a farm vehicle public road crash (1992-2003) with farms that had not experienced one. A total of 14,800 phone numbers were called. The calling list was randomly selected and ordered from a USDA agricultural program database $(n=46,910)$ of North Carolina resident farm operators and owner/operators. Approximately 76 percent of numbers called allowed successful screening. Approximately 26 percent of calls screened met inclusion eligibility. Response to a 20-minute telephone survey was 100 percent among eligible farm operators and owner/operators actively farming, 18 years or older, and driving farm vehicles on public roads. A sample of $n=200$ crash cases and $\mathrm{n}=185$ no-crash controls were available for data analysis for an approximate 1:1 case : control ratio.

The combined logistic regression model of eighteen driver, vehicle and environmental characteristics was significant for crash group membership differences $\left(X^{2}=192\right.$, $\left.\mathrm{df}=18, p<.0001\right)$. Eight characteristics (i.e., six driver, one vehicle and one environmental) were associated with increased odds of crash group membership as hypothesized: non-English speaking help drivers ( $\mathrm{OR}=4.61)$; nonfamily hired help drivers $(\mathrm{OR}=4.32)$; public road conflict $(\mathrm{OR}=1.77)$; non-farm vehicle public road use $(\mathrm{OR}=1.40)$; farm injury history $(\mathrm{OR}=1.34)$; and, younger farm vehicle drivers $(\mathrm{OR}=1.02)$.

Farms reporting older farm vehicle drivers $(\mathrm{OR}=0.96)$, increased perception of farm vehicle public road driving danger $(\mathrm{OR}=0.53)$, and low farm income $(\mathrm{OR}=0.26)$ were less likely crash group members.

Recommendations are discussed for incorporating combined driver, vehicle and environmental risk factors and preventive characteristics into farm vehicle crash prevention research and interventions. 


\title{
RISK FACTORS FOR A FARM VEHICLE PUBLIC ROAD CRASH
}

by

\section{THERESA M. COSTELLO}

\author{
A dissertation submitted to the Graduate Faculty of \\ North Carolina State University \\ in partial fulfillment of the \\ requirements for the Degree of \\ Doctor of Philosophy
}

\section{PSYCHOLOGY}

\section{Raleigh}

2005

\section{APPROVED BY:}




\section{Dedication}

“Give us this day our daily bread...."

This research is dedicated to farmers and farm communities from whom I have learned so much. Thank you for our daily bread, and may this research help address a major safety concern, i.e., farm vehicle public road crashes. 


\section{Biography}

Dr. Theresa Costello was born in Norfolk, Virginia on April 6, 1957, the fifth of seven siblings. Dr. Costello grew up in Western Maryland. In her Junior year of high school, she lived with a German family (Franz and Gudrun Schmuck and children) in Deggendorf, Niederbayern and attended the local German high school, i.e., Comenius Gymnasium. Building on her language skills and international experience, Dr. Costello completed four degrees prior to her doctorate: B.A. in German and Italian literature from Middlebury College in Middlebury, Vermont; B.S. in Physical Therapy from the Ohio State University (OSU) in Columbus, Ohio; an MBA in International Management from the American Graduate School of International Management in Glendale, Arizona; and, M.S. in Psychology in the Public Interest from North Carolina State University (NCSU) in Raleigh, North Carolina.

Prior to attending graduate school for Psychology in the Public Interest (PPI), Dr. Costello was involved in national and international marketing, in particular new product/business development, in a variety of industries including: personal care products, household goods, health care, and footwear.

Dr. Costello is a licensed physical therapist. While in Physical Therapy school at OSU, Dr. Costello worked as a Physical Therapy assistant at OSU's in-house rehab center (Dodd Hall) and as a research assistant in the OSU Gait (Movement) Analysis Laboratory. She also worked as a live-in caregiver. After graduation, Dr. Costello worked as a physical therapist in nursing care and rehabilitation facilities. First hand experience of the role environment plays in a person's ability to remain independent and safe from injury and illness prompted Dr. Costello to seek her doctorate in Psychology in the Public Interest (i.e., Community Psychology) from NCSU.

While completing her NCSU doctoral studies, Dr. Costello worked as a researcher, instructor, physical therapist, and live-in caregiver. Dr. Costello's research, intervention and publication efforts address: occupational injury and illness surveillance; work related musculoskeletal discomfort (WMSD) prevention and treatment; farm vehicle public road safety; and, reflective material use for pedestrian safety. In the future, Dr. Costello plans to continue in the areas of health, safety and community development as an instructor, researcher and practitioner. 


\section{Acknowledgments}

Thank you to my committee members. It has been an honor to work with you and I appreciate so much the help and guidance provided in completing my doctorate. Dr. Roger Mitchell, my committee chair and program advisor, helped manage the process and keep things moving forward. I have enjoyed our many conversations. They helped me see the world from new perspectives and to ask good questions. Dr. Michael Schulman, committee member, NCSU Sociology Department faculty member, principle investigator for the farm vehicle public road safety project, and mentor. Dr. Schulman's knowledge, humor and love of agriculture, community, and social relationships offered a rich learning ground. Working with Dr. Schulman for four years has brought home the truism that in graduate school one often learns more outside of the classroom than inside it. I am grateful for his wise suggestions, and the freedom offered to make mistakes and then learn from them. Dr. Michael Wogalter, committee member and NCSU Psychology Department faculty member. Thank you for motivating me to do things I might not have done on my own, and for teaching me to communicate more concisely and thus more effectively. It was a privilege to work with you. Dr. Dan Bauer, committee member and University of North Carolina Chapel Hill (UNC-CH) Psychology Department faculty member. Your simple explanations of often complex relationships and analyses were a great gift in learning to navigate the idiosyncracies of social science research. Thank you.

The world would not be the same without people like Darnell Johnson, the NCSU Psychology graduate program coordinator, and Joy Smith, SAS expert in the NCSU Statistics Department and College of Agricultural Life Sciences. Darnell always had a fresh supply of quality chocolate to save the day, besides knowing what form needed to be signed and the exact kind of paper required. Joy Smith’s knowledge of SAS and mutual fondness for skinny latte's frequently saved the day as well. A visit to Poe Hall was never complete without a stop at the Psychology Department (thanks to Susie Hunter, Candi Jacobs and Julia Matthews-Richardson), and at the Learning Resource Library to say hi to fellow gradual students and Chrys. Chrys always made sure that I was “audiovisually correct” when working as an instructor or teaching assistant, besides having a kind word of encouragement when the light at the end of the tunnel did not seem so bright. Thank you also to Rosina at the Help Desk for her technical assistance. Thank you to Dr.'s Sam Snyder, Donald Mershon, David Martin, and the NCSU Psychology faculty, in 
particular Slater Newman and Debra Holden, for their support and guidance. Thanks also to the NCSU Sociology Department staff and faculty, who so kindly helped with questions and paperwork. A special thanks to Dr.’s Ron Czaja and Cathy Zimmer for their time and patience in answering my unending stream of questions. Thanks also to the following groups for their support: the NIOSH agricultural safety and health group for funding my research projects; the North Carolina Agromedicine Institute; North Carolina Department of Labor, Agricultural Safety and Health Division (in particular, Regina Luginbuhl); North Carolina Department of Transportation; and the University of North Carolina Chapel Hill Highway Safety Research Center (in particular, Dr.'s Ron Hughes and Eric Rogdman), and the North Carolina Community Health Center Association. Thanks to Dr. David Dickey of the NCSU Department of Statistics for his help and guidance. And, thank you to Walter and Jean Wilkinson, Jr. for their support of research ethics.

Thank you to my parents, family, relatives, friends, fellow graduate students, my students, mentors, teachers, and all the other people I have encountered in life. You have helped make me who I am, and so are a part of this project. A special debt of gratitude to my roommate, Martin Perry, who gave me a stable and enjoyable living environment in which to complete my doctorate. Special thanks as well to Martin's dad, Al, friend, Betsy, and sons, Nathan and Matt, for always making me feel welcome and part of their family. Thank you also to my many mentors, Joan, Stephanie, Rhonda, and others for helping me see more clearly and listen more intently from different perspectives.

And last but not least, thank you to the farmers and farm community members (especially Dan Andrews and Andrews Farms, Fuquay Varina, NC), whose motivation made this research possible. It has been a wonderful and unique learning experience. 


\section{TABLE OF CONTENTS}

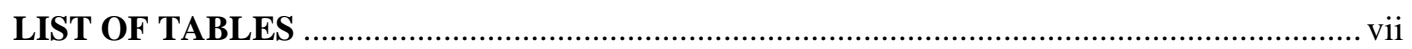

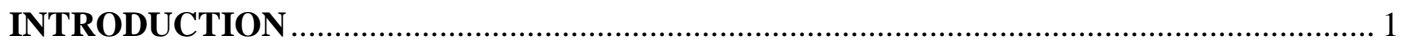

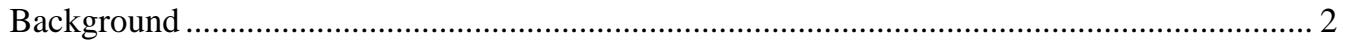

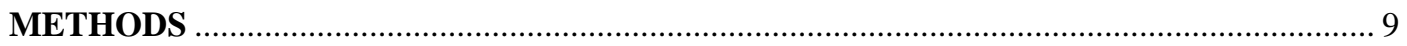

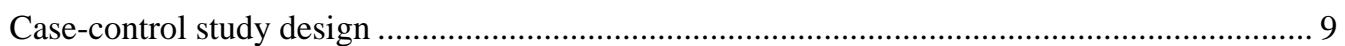

Crash case time frame .............................................................................................. 10

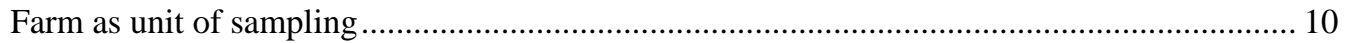

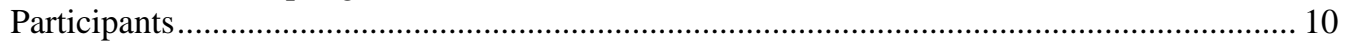

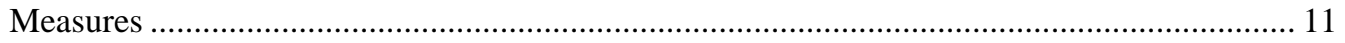

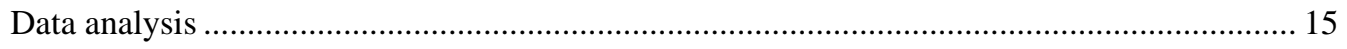

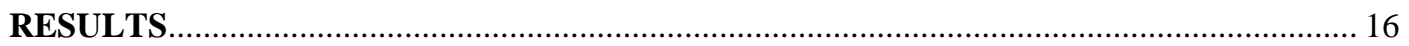

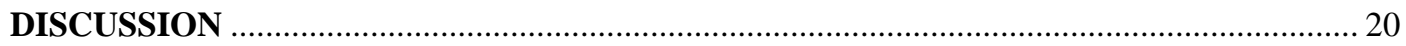

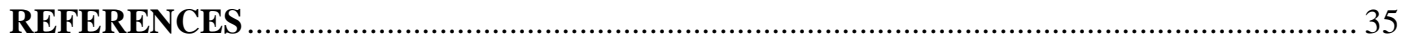

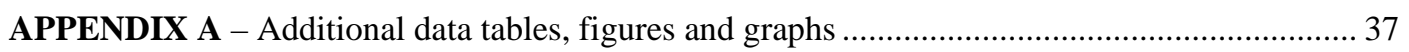

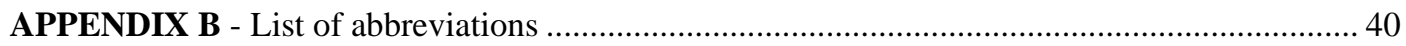

APPENDIX C -Farm vehicle public road crash study press release ....................................... 42

APPENDIX D -Farm vehicle public road crash telephone survey informed consent script.......... 45

APPENDIX E -Farm vehicle public road crash telephone survey and codebook ...................... 47 


\section{LIST OF TABLES}

Table 1. Demographic characteristics of total sample $(n=385)$ compared with USDA agricultural census data for North Carolina....

Table 2. Independent variable means and frequency percentages for the total sample and by farm vehicle public road crash status, and chi square or t-test results for crash versus no crash group comparisons.

Table 3. Logistic regression Wald statistic, odds ratio piont estimates and confidence limits $(n=385)$. 


\section{RISK FACTORS FOR A FARM VEHICLE PUBLIC ROAD CRASH}

\section{INTRODUCTION}

Driving on public roads is dangerous (Batten, 2000). As a cause of death, public road crashes are rivaled only by chronic heart disease and cancer (Batten, 2000; Lakshmanan, 2000). Public road crashes globally are expected to increase from a $9^{\text {th }}$ ranking in 1990 to a $3^{\text {rd }}$ ranking in the year 2020 for public health disease burden, thus making them a major public health and safety issue, both nationally and internationally (von Holst, 2000).

Farm vehicle public road crashes are a major safety concern for farmers driving farm vehicles on public roads (Costello et al., 2003; Luginbuhl et al., 2003; NCDOL, 1999) even though farm vehicle public road crashes are a rare event, representing less than 1 percent of North Carolina annual public road crashes (Costello et al., 2003). Farm vehicle drivers appear at higher risk for a public road crash than non-farm vehicle drivers when exposure, i.e., vehicle miles traveled (VMT), is considered (Costello et al., 2003; Glascock, et al., 1995). When a farm vehicle public road crash does occur, it is five times more likely to result in a fatality than a non-farm vehicle-type crash (American Trucking Associations, 2000).

Although farmers and agricultural health and safety experts are aware of the dangers involved in operating farm vehicles on public roads, few empirical studies of farm vehicle public road crashes have been conducted (Costello et al., 2003: Gerberich et al., 1996; McCurdy and Carroll, 2000). Thus, transportation related accident and injury reduction frameworks and literature were used to identify potentially relevant risk factors. Transportation related accident and injury prevention frameworks, such as the Haddon matrix (O’Neill et al., 2002), take into consideration driver, vehicle and environmental characteristics when identifying and assessing risk factors for public road crashes. Similarly, this study looked at the combined association of driver, vehicle and environmental characteristics with farm vehicle public road crash group membership. 


\section{Background}

This study attempts to make a contribution to the literature by, first, using a broadened conceptual framework for examining farm vehicle public road crash risk factors, and second, sampling data at the level of the farm rather than at the level of the individual driver.

Farm vehicle public road crash research has relied primarily on public road crash report data (Gerberich et al., 1996; McCurdy et al, 2000; Murphy, 2003). This reliance on crash report data may have limited the conceptual focus of farm vehicle public road crash research by not prompting a broader view of the types of risk factors that might be involved. For example, the safety climate on a farm may influence the training provided to drivers and the availability of safety equipment on farm vehicles. Neither of these factors would be captured by public road crash data. Similarly, agriculture-related injury and fatality study findings suggest non-family, hired help, in particular non-English speaking help, are at higher accident risk than farm family help (McCurdy et al., 2000). Crash report data provide information regarding the age and gender of farm vehicle drivers involved in a crash, but do not report the farm vehicle driver's work status (i.e., is a farm operator or owner/operator or farm help). In contrast, an examination of factors that examine farm, public roadway, vehicle and driver characteristics may provide a broadened and more powerful picture of the factors related to farm vehicle public road crashes. Agriculture-related injury and fatality studies, in particular ones involving farm vehicles, and public road crash studies were examined for relevant risk factors.

This study used the farm as the unit of analysis in examining the prevalence of farm vehicle public road crashes. This approach was taken for several reasons. First, since many of the factors hypothesized to affect crash status are at the farm level, use of the farm as the unit of selection and analysis seems compelling. Second there are practical issues that advocate sampling at the farm level. Identification of the population of individuals who drive farm vehicles on public roads is much more difficult than identifying the population of farms. Finally, public road farm vehicle crashes are a rare event. It seemed more feasible to sample farms and classify those in which an owner /operator had been in a crash than to try to draw a sample of individual drivers and classify them as to their crash versus non-crash experience.

Farm operators or owner/operators are interviewed in this study about the characteristics of drivers, vehicles, public roadways, and the operation of their farm itself. Thus, farm vehicle driver, vehicle, 
and public road and farm environmental characteristics are used to distinguish which farms have a greater likelihood of being in the group having sustained a crash, rather than being used to distinguish the characteristics of drivers or vehicles that were actually involved in a farm vehicle public road crash.

\section{Driver risk factors}

Driver characteristics identified in the literature as increasing the risk for a public road crash or a farm vehicle accident were: farm vehicle driver age (Doss et al, 1972; McCurdy et al., 2000); public road driving exposure (i.e., vehicle miles traveled [VMT]) (Costello et al., 2003; Ogden, 1997); farm help status (Layde et al., 1993,1995); and, safety behavior (Grieshop et al., 1996; McCurdy et al., 2000). Each driver characteristic is discussed individually below.

Younger and older individuals are often at higher risk for an accident and injury than middle age individuals, but for different reasons (McCurdy et al., 2000). Younger individuals, in particular drivers, may lack skill and experience (Gerberich et al., 1995; McCurdy et al., 2000). Older individuals on the other hand may have sensory and muscular deficits brought on by aging, as well as other medical conditions, that put them at increased risk for an accident (Pickett, et al., 1996). Thus, it was posited that farms with respondents reporting younger and older farm vehicle drivers are more likely members of the farm vehicle public road crash group than farms reporting middle age range farm vehicle drivers.

Public road driving exposure findings suggest a curvilinear relationship with crash status. Individuals with low driving exposure may be at higher risk for a crash because of limited driving time and, thus, potentially less driving skill and experience (Assum, 1997). Individuals with high driving exposure may be at greater risk for a crash simply because they have more opportunities to experience one (Ogden, 1997).

Farmers reported driving farm vehicles on public roads a median of three to five miles per day (VMT) based on a sample $(\mathrm{n}=194)$ of North Carolina farmers (Costello et al., 2001). A mean of 20 miles were driven per day with a range from less than 1 mile to more than 500 miles driven per day. These findings suggest that the range of public road driving exposure for farm vehicles spans from low to high numbers of miles traveled per day. It was posited that farms with respondents reporting lower and higher 
levels of public road driving exposure are more likely farm vehicle public road crash group members than farms in the middle range of public road driving exposure.

Farm help status, specifically being non-family or non-English speaking help, has been identified by farm injury and fatality study findings as increasing the risk for an accident (McCurdy et al., 2000). A variety of factors may contribute to increased accident risk for non-family and non-English speaking farm help, for example: less experience with agriculture, which is a highly hazardous occupation (McCurdy et al., 2000); language barriers which decrease the effectiveness of communicating and understanding farm safety information (Grieshop et al., 1996); or a diminished ability to influence the level of risk exposure for a farm accident because of one's non-family help status (McCurdy et al., 2000). Thus, it was posited that farms with respondents reporting non-family hired help driving farm vehicles on public roads, in particular non-English speaking farm help, are more likely members of the farm vehicle public road crash group.

Safety behavior has been associated with decreased accident risk (Geller, 2001; McCurdy et al., 2000). A farm environment which values safe work habits and proactive safety characteristics and behavior is less likely to be involved in a farm related accident (Grieshop et al., 1996). Three safety characteristics and behaviors associated with farm related accidents were examined in this study: farm injury history (McCurdy et al., 2000; Browning et al., 1998); perception of danger (Grieshop et al., 1996; Bernstein, 1998); and crash preventive actions taken (Grieshop et al., 1996; Luginbuhl et al., 2003). Each characteristic is discussed below.

A history of accidents and injuries is associated with an increased risk for additional accidents and injuries (McCurdy et al., 2000; Norris et al., 2000). Individuals with a history of injury or current work limitations are at up to four fold increased risk for another accident or injury (Browning et al.,1998). Given this association between prior accidents and injuries and the risk for future ones, it was posited that farms with respondents reporting a history of farm accidents and injuries are associated with farm vehicle public road crash group membership.

Perception of danger can represent the accident risk involved in an activity, such as driving farm vehicles on public roads (Berstein, 1998; Grieshop et al., 1996; Laughery et al., 1998). Agriculture is a very hazardous occupation (Murphy, 2003). Findings by Grieshop et al. (1996) suggest that farmers and farm help are aware of the dangers of their work environment. The farmers' perception of the danger of 
driving farm vehicles on public roads was proposed as a measure of the farm's risk of experiencing a farm vehicle crash. Thus, it was posited that farms with respondents reporting a higher perception of the danger of driving farm vehicles on public roads are more likely members of the farm vehicle public road crash group.

Preventive actions are taken to minimize loss in risk management (Bernstein, 1998). Thus, farmers would be expected to take preventive action to minimize the risk of a farm vehicle public road crash. North Carolina farmers reported implementing a variety of safety measures to reduce the risk of a farm vehicle public road crash in a study by Luginbuhl et al. (2003). Safety measures consisted of such activities as increased driver education and training, improved lighting and signage on vehicles, and use of lead cars. Building on this literature, this study posited that farms with respondents reporting a greater number of farm vehicle public road crash preventive actions taken are less likely members of the farm vehicle public road crash group.

\section{Vehicle risk factors}

Vehicle risk factors involved both farm and non-farm vehicles in this study. Farm vehicle related risk factors identified in the literature were farm vehicle age and type. The non-farm vehicle related risk factor identified was the number and variety of non-farm vehicle uses of public roads. Each is discussed by characteristic group below, beginning with farm vehicle risk factors.

Farm vehicle age and type contribute to public road crash risk in different ways (Gerberich et al., 1996; Murphy, 2003). Farm vehicle types addressed in this study include large size farm vehicles and farm trucks. Farm vehicle age and type characteristics and their roles as risk factors are discussed below.

Older farm vehicles may be at higher risk for a public road crash, especially if they were manufactured before the 1976 implementation of non-mandatory standards for farm vehicle lighting, signaling and signage (ASAE, 1998, 2002). Farm vehicles manufactured prior to 1976 are less likely to be equipped with high visibility lighting and signaling technology, unless the farm vehicle was retrofitted. Thus, it was posited that farms with respondents reporting driving older farm vehicles on public roads are more likely members of the farm vehicle public road crash group.

Two farm vehicle type characteristics were identified in the literature as potentially increasing the risk for a farm vehicle public road crash, namely, large size farm vehicles and farm trucks. Although 90 
percent of officially reported farm vehicle public road crashes in North Carolina between 1995 and 1999 involved farm tractors (Hughes et al., 2000), ten percent were accounted for by a general classification group of undifferentiated, self-propelled farm equipment (Lacy et al., 2001; Luginbuhl et al., 2003). The shift in agriculture toward larger sized farms has prompted the use of larger sized farm vehicles to more cost effectively cultivate and harvest agricultural goods (Mason, 2003). It seems plausible that larger sized farm vehicles could pose an increased public road hazard. Thus, this study posited that farms with respondents reporting driving large size farm vehicles on public roads are more likely members of the farm vehicle public road crash group.

Farm truck crashes are not directly reported in public road crash statistics, rather are included undifferentiated in the all truck type crash category (Luginbuhl et al., 2003). For that reason, farm truck crashes are not included in available farm vehicle public road crash statistics. Farm trucks are frequently used to transport equipment, workers and agricultural goods on public roads (Mason, 2003). Farm labor contractors may provide transportation, sometimes as a condition of employment (McCurdy et al., 2000). Farm labor contractors often utilize overloaded, unsafe vehicles and inexperienced drivers to transport workers, as well as farm products and supplies (McCurdy et al., 2000). Therefore, it is plausible that farm truck use increases public road crash risk. This study thus posited that farms with respondents reporting driving farm trucks on public roads are more likely members of the farm vehicle public road crash group.

Non-farm vehicle use of North Carolina public roads has increased in both number and variety over the last twenty years with the influx of over 2 million new residents (Costello et al., 2003; Luginbuhl et al., 2003; NCOSPL, 1997, 2000). Farm vehicles are now sharing once quiet, seldom traveled, two-lane rural roads with more and different types of non-farm vehicles (Glascock et al., 1995). Crash report data support the perspective that farm vehicle public road sharing is becoming a more complex social phenomenon (Batten, 2000). Passenger cars are most frequently involved in farm vehicle public road crashes, followed by trucks, then a number of other non-farm vehicle types (Glascock et al., 1995; Hughes et al., 2000). Passenger cars use public roads for such things as: taking children to school, commuting to work, and running errands. Trucks and other types of non-farm vehicles use public roads for transporting goods to market or to construction sites, etc. Each of these types of public road use is expected to have its own public road use characteristics and risk level for a farm vehicle public road crash. Combined, the 
number and variety of road uses mentioned is expected to reflect the complexity of the social phenomenon of public road sharing with farm vehicles. Thus, this study posited that farms with respondents reporting a higher number of public road uses by non-farm vehicles are more likely members of the farm vehicle public road crash group.

\section{Environmental risk factors}

This study examined not only public road environment characteristics that may contribute to farm vehicle public road crash group membership, but farm environment characteristics as well. Farm environment characteristics were included because of the unique characteristics of agricultural production, which might influence farm vehicle public road use. Public road environment characteristics and risk factors will be discussed first, followed by the farm environment ones.

Regarding the public road environment, traffic density and public road driving conflict have been associated with an increased risk for a crash (Ogden, 1997; Satterthwaite, 1981). Traffic density will be discussed first, then public road driving conflict.

Traffic density is defined as the number of cars on the road during a specific time period (Ogden, 1997). A curvilinear relationship with public road crashes is suggested by traffic density research findings (Satterthwaite, 1981). Farm vehicle drivers encountering low and high levels of traffic density are associated with increased risk of a crash, but for different reasons (Satterthwaite, 1981). Speed often contributes to low traffic density crashes (Gerberich et al., 1995; Glascock et al., 1995). Public road conflict is associated more strongly with high traffic density crashes (Satterthwaite, 1981). Thus, this study posited that farms with respondents reporting high and low traffic density are more likely members of the farm vehicle public road crash group than farms reporting medium traffic density.

Conflict is inherent in sharing public resources (Kita, 2000), and public road conflict contributes to crashes (Satterthwaite, 1981). Given farmers' knowledge of the hazards of farm work (Grieshop et al., 1995; Murphy, 2003), farm vehicle drivers’ perception of the conflict encountered driving on public roads should function as an appropriate measure of farm vehicle public road driving conflict. Thus, this study posited that farms with respondents reporting higher levels of farm public road driving conflict are more likely members of the farm vehicle public road crash group. 
Generally, public road crash studies only take the public road environment into consideration. Since agricultural production has unique characteristics that may impact farm vehicle public road use, this study also included characteristics of the farm environment. Farm characteristics identified in the literature as increasing the risk for accidents or injuries were: number of farm operations (McCurdy et al., 2000); and farm income (McCurdy et al., 2000; Gerberich et al., 1996). Each is discussed below.

An increase in the number of noncontiguous farm operations managed has been a primary characteristic of agricultural acreage and production growth in the last twenty years (USDA, 1999). This increase in the number of farm operations managed, in turn, may have increased the need for farmers and farm help to drive farm vehicles on public roads (USDOT, 1971, Mason, 2003). An increase in public road driving exposure has been posited to increase the risk for a farm vehicle public road crash. Building on these findings, this study posited that farms with respondents reporting higher numbers of farm operations are more likely members of the farm vehicle public road crash group.

Farm size is associated with increased farm accident and injury risk in a number of ways. Prior studies suggest that small and large farm environments put farmers and farm help at greater risk for accidents and injuries than medium size farm environments, but for different reasons (Hoskins et al., 1988; McCurdy et al., 2000). Findings suggest that smaller farms are at increased risk for accidents or injuries because of the pressures of getting the farm work done under time pressure constraints, often with limited help (Gerberich et al., 1996; McCurdy et al., 2000). Large farms may be at increased risk for an accident or injury because high risk jobs such as driving farm vehicles on public roads may be delegated to farm help, who may not be adequately trained and/or have the appropriate skills or knowledge base to complete the task safely, e.g., drive farm vehicles on public roads (McCurdy et al., 2000; Murphy, 2003).

Farm size is often measured in agricultural studies using farm income as a proxy variable (McCurdy et al., 2000; Murphy, 2003; USDA, 1999). Building on the findings regarding farm size and the use of farm income as a proxy for farm size, this study posited that farms with respondents reporting small and large annual gross farm sales as a proxy for farm size are more likely members of the farm vehicle public road crash group than farms reporting medium annual gross farm sales. 
Summary of literature review findings and implications for this research study

Farm vehicle public road crashes are complex social phenomena that occur within the context of the public road environment (Batten, 2000). Inherent in the use of limited public resources such as public roads is the act of "sharing." The complex nature of this public road "sharing" relationship suggests that a combination of "driver-vehicle-public road and farm environment" characteristics are associated with farm vehicle public road crash risk. Human error is most frequently identified as the cause of accidents and injuries (Laughery et al., 1999). Yet, few studies were found that took into consideration the combined association of driver, vehicle and environmental characteristics with public road crash risk. Thus building on the literature review findings presented, this study was designed to answer the following research question: "to what extent are driver, vehicle, public road and farm environmental characteristics, combined, associated with an increased likelihood of farm vehicle public road crash group membership?”

\section{METHODS}

Case-control study design

A case-control design was used to compare farms reporting a farm vehicle public road crash (1992 - 2003) with farms that had not experienced a crash. A case was defined in this study as a North Carolina resident farm operator or owner/operator, who met the following criteria: drives farm vehicles on public roads; is 18 years of age or older; and either he/she or the farm help had experienced a farm vehicle public road crash between 1992 and 2003. Controls met the same screening criteria, except that neither the farmer respondent nor the farm help had experienced a farm vehicle crash between 1992 and 2003.

A case-control design was selected for this study, first, because farm vehicle public road crashes are a rare event. A case-control design is considered a cost effective and statistically sound design for rare event studies (Rothman, 2002; Rothman et al., 1998; Schlesselman, 1982). Second, the study proposed to identify crash group membership differences. The case-control design accommodates the assessment of past exposures and multiple covariates with a dichotomous dependent variable, such as farm vehicle public road crash group membership (Pickett et al., 1996). 


\section{Crash case time frame}

Initially, a ten year time frame (1992 - 2002) was selected as the study inclusion period as a case because of the small number of farm vehicle crashes reported each year on North Carolina public roads, i.e., approximately 300 crashes annually, and the associated costs of locating and interviewing eligible cases. Fielding was delayed by one year due to issues pertaining to the release of the USDA list, thus the time frame was increased to include cases identified that occurred during the survey period of January through April 2003.

\section{Farm as unit of sampling}

This study used the farm as the unit of sampling and analysis in examining the prevalence and characteristics of farm vehicle public road crashes. Since many of the factors hypothesized to affect crash status are at the farm level, selection of the farm as the unit of sampling and analysis seems compelling. Farm operators or owner/operators were interviewed in this study about the characteristics of drivers, vehicles, public roadways, and the operation of their farm itself. Thus, farm vehicle driver, vehicle, and public road and farm environmental characteristics were used to identify farms with greater likelihood for farm vehicle public road crash group membership.

\section{Participants}

A USDA-sponsored agricultural program database provided a list of North Carolina resident farm operators and owner/operators with unique phone numbers $(n=46,910)$ from which a SAS program for random selection without replacement and random ordering generated 20,000 telephone numbers for sequential calling. A total of 14,800 phone numbers were called. Of those 14, 800 calls, 24 percent were unable to be screened for the following reasons. Approximately 1.4 percent of calls were to individuals who refused to be screened. Approximately 22 percent of calls were placed to numbers that were either out of service $(n=1,807)$, no longer where a farmer lives $(n=683)$, or could not be contacted $(n=807)$. Approximately 76 percent of the total 14,800 numbers called (i.e., 11,299 numbers) were to households that allowed successful screening. Approximately 26 percent $(n=3,902)$ of households successfully screened met eligibility criteria for possible inclusion in the study. The eligibility criteria were: North 
Carolina resident farm operators or owner/operators; 18 years of age or older; actively farming; and, reporting driving farm vehicles on public roads at the time of the study.

At the outset of the study, each eligible individual was asked to participate in a 20 minute telephone survey, which included a question as to whether he/she or his/her farm help had experienced a farm vehicle public road crash between 1992 and 2003. A total of 236 interviews (i.e., with 208 no-crash respondents and 28 crash case respondents) were completed to meet the sampling quota minimum of 200 no crash controls. From that point on, eligible individuals were asked to complete the interview only if they or their farm help had experienced a farm vehicle public road crash between 1992 and 2003. A total of 188 crash case surveys were completed in the second phase of sampling. Combined with the 28 crash cases identified in the first phase of interviewing, a total of 216 crash cases were available for data analysis. Altogether, a sample of 216 farm vehicle public road crash cases and 208 no-crash controls resulted in a 1 : 1 case-control ratio. No eligible individuals who were asked to complete the survey refused.

\section{Measures}

All measures in this study were self-report with the farm operator or owner/operator respondent reporting characteristics of farm vehicle public road use for his/her respective farm, rather than for a specific driver.

The dependent variable in this study was dichotomous, with crashes defined as either the farm operator or owner/operator or his/her farm help having experienced a farm vehicle public road crash between 1992 and 2003. Crashes were coded as 1, and no-crashes as zero (0), as SAS LOGISTIC runs logistic regression in descending order.

The independent variables, i.e., driver, vehicle, and environmental risk factors for a farm vehicle public road crash, were measured as described below. Farm vehicle public road crash group membership differences were measured in this study at the farm level at the time of the survey, rather than at the level of the individual driver at the time of the farm vehicle public road crash. Farm operators or owner/operators were asked questions about the status of driver, vehicle and environmental characteristics at the time of the interview, rather than at the time of the crash. 
Farm vehicle driver variables included in the research model were: farm vehicle driver age, farm help status, public road driving exposure, and safety behavior. Each variable and how it was measured is presented below.

Farm vehicle driver age was measured by asking farm operator or owner/operator respondents two questions regarding the age of farm vehicle public road drivers for their farm:

Younger farm vehicle drivers - was measured by asking farm operator or owner/operator respondents the age of the youngest individual driving farm vehicles on public roads for their farm. A curvilinear relationship was posited for youngest farm vehicle driver and crash status. Younger drivers were posited to be at increased likelihood for farm vehicle public road crash group membership. Therefore, data analysis and model testing included a quadratic variable to determine statistical significance and the benefit of including the quadratic variable in the full research model.

Older farm vehicle drivers - was measured by asking farm operator or owner/operator respondents the age of the oldest individual driving farm vehicles on public roads for their farm. A curvilinear relationship was posited for oldest farm vehicle driver and crash status. Older drivers were posited to be at increased likelihood for farm vehicle public road crash group membership. Therefore, data analysis and model testing included a quadratic variable to determine statistical significance and the benefit of including the quadratic variable in the full research model.

Farm help status was measured by asking farm operators or owner/operators whether they have non-family hired help driving farm vehicles on public roads. Yes responses were coded as 1 and no responses were coded as zero (0).

Non-English speaking help status was measured by asking farm operators or owner/operators whether any of their farm help driving farm vehicles on public roads were non-English speaking. This variable, initially measured continuously (i.e., "how many...”), was dichotomized so that Yes responses were coded as 1 and no responses were coded zero (0).

Public road driving exposure was measured by asking farm operators or owner/operators the number of hours per week they or their farm help drive farm vehicles on public roads during busy months. A curvilinear relationship was posited for number of hours drive farm vehicles on public roads. Therefore, data analysis and model testing included a quadratic variable for number of hours drive farm vehicles on 
public roads to determine statistical significance and the benefit of including the quadratic variable in the full research model.

Safety behavior was measured using three variables: (1) farm injury history; (2) perception of farm vehicle public road driving danger; and (3) crash preventive actions taken. Each is discussed below. Farm injury history was measured by asking farm operators or owner/operators how many times while working in agriculture they had been injured badly enough on the job to miss a day of work or receive medical treatment.

Perception of farm vehicle public road driving danger was measured by asking farm operators or owners whether they strongly agree (4), agree (3), disagree (2), or strongly disagree (1) with the statement that "driving farm vehicles on public roads is dangerous."

Crash preventive actions taken were measured by asking farm operators or owner/operators the following open-ended question: "what kind of things have you or your farm help ever done to avoid a farm vehicle public road crash?” The responses were summed. Examples of actions taken included: using lead or follow cars; adding extra lighting and signage to equipment; requesting more road signs; and installing safety features. Summary scores ranged from zero (0) to five (5) crash preventive actions taken. Higher scores indicated more farm vehicle public road crash preventive actions taken.

Vehicle variables included in the research model addressed both farm and non-farm vehicles sharing public roads, namely farm vehicle age and type and non-farm vehicle public road use. Each is discussed below beginning with the farm vehicle variables.

Farm vehicle age was measured by asking farm operators or owner/operators the age of the farm vehicles they drive on public roads. The age of the oldest farm vehicle mentioned was used for data analysis and model testing.

Several farm vehicle type characteristics were assessed in this study: farm trucks (i.e., pick up trucks and dump trucks) and large size farm vehicles (i.e., combines, harvesters, specialty equipment and hay balers). Each farm vehicle type and how it is measured is discussed below.

Farm truck - usage was measured by asking farm operators or owner/operators what types of farm vehicles they or their farm help drive, tow or load and transport on public roads, besides farm tractors. 
Farm truck types mentioned were summed as zero (0) for no mention or one (1) for one or more mentions for use in data analysis and model testing.

Large size farm vehicle - usage was measured by asking farm operators or owner/operators what types of farm vehicles they or their farm help drive, tow or load and transport on public roads, besides farm tractors. Large size farm vehicle types mentioned were summed as zero (0) for no mention or one (1) for one or more mentions for use in data analysis and model testing.

Non-farm vehicle public road use characteristics were measured by asking farm operators or owner/operators the following open-ended question: "what are the roads you use to transport farm equipment used for besides farming?” Responses were summed for use in data analysis and model testing. Examples of non-farm vehicle public road use included: local traffic; commuter route; construction site access; livestock trucking route; construction route. Summary scores ranged from one (1) to seven (7) nonfarm vehicle public road uses. Higher scores indicated a greater number and variety of non-farm vehicle public road uses.

Environmental characteristics included in the research model addressed the public road and farm environments. Each are discussed below beginning with the public road.

Public road environment characteristics, specifically the "sharing” relationship between farm and nonfarm vehicles, were measured by asking farm operators or owner/operators two questions, one regarding traffic density and the other regarding public road conflict.

Traffic density was measured by asking farm operators and owner/operators whether their farm was located in an area with: (1) little traffic, (2) moderate traffic, or (3) heavy traffic. Response frequencies were used for data analysis and model testing.

Public road conflict was measured by asking: “over the last 10 years, would you say the number of times you or your farm help could have ended up in a crash has: (1) decreased, (2) stayed about the same, (3) increased, (4) increased a lot; or (5) increased so much I avoid driving on public roads?” Likert scale responses ranging from one to five were used as a continuous variable for data analysis and model testing.

Farm environment characteristics included in the research model were number of farm operations and annual gross farm income. 
Number of farm operations was measured by asking farm operators or owner/operators "how many farm operations they own or manage.”

Farm income was measured using nine US agricultural census data categories for gross annual farm sales that aggregate into three income category groups, namely: low income $(<\$ 25,000$ annual gross farm sales); medium income (\$25,000 to $\$ 99,999$ annual gross farm sales); and high income $(\$ 100,000$ or greater annual gross farm sales) (USDA, 1999).

\section{Data analysis}

Logistic regression was used to test the proposed research model and hypotheses regarding farm vehicle public road crash group membership differences. As mentioned above, several variables in the model were measured and used as continuous variables for data analysis and model testing: age of youngest farm vehicle driver; age of oldest farm vehicle driver; number of hours drive farm vehicles on public roads per week during busy months; farm injury history; and, number of farm operations. Several variables were measured using Likert scales: perception of farm vehicle public road crash danger; and, public road driving conflict. These measures were treated as continuous variables for data analysis and model testing purposes. All others were either dichotomous or dummy variables. All measures were pretested in a pilot study $(\mathrm{n}=30)$ and modified as appropriate prior to data collection.

SAS for Windows was used for all data analyses. Outliers were identified using the following criteria: A Cook CI-interval displacement statistic of .13 or greater; and a positive change in all three of the following statistics, namely, the logistic regression $\mathrm{X}^{2}$, and the linear regression $\mathrm{R}^{2}$, and $\mathrm{R}^{2}$ adjusted when variable was deleted from the model. After cleaning data for outliers $(n=9)$ and missing data $(n=30)$, a sample of $\mathrm{n}=200$ crash cases and $\mathrm{n}=185$ no-crash controls were available for data analysis.

A combined model of driver, vehicle and environmental variables posited to be associated with farm vehicle public road crash group membership was compared with the constant-only model by means of a likelihood ratio test at a $p<.05$ significance level. Individual variable hypotheses were tested using the Wald statistic and the odds ratio point estimate, along with the 95\% Wald confidence limits. 


\section{RESULTS}

Sample Description

The mean age of North Carolina resident farm operators or owner/operators in this study $(\mathrm{n}=385)$ was 55 years, which is comparable to USDA agricultural census data (1999) for North Carolina (mean = 55 years). Mean acreage for the study sample was 539 acres, which was higher than the North Carolina census mean of 185 acres. A mean annual gross farm sales of $\$ 133,000$ for this sample was lower than the North Carolina census mean of $\$ 155,000$. This study’s sample represents a smaller percentage of low income farms (28\%) than the North Carolina (67\%) USDA agricultural census data, and a higher percentage of medium and large income farms.

These findings suggest that, although the study sample is similar in age to the North Carolina agricultural census population, North Carolina resident farm operators or owner/operators included in the USDA agricultural program database may differ somewhat from the average US Census data profile for North Carolina farmers. Farm operators or owner/operators in this study reported lower annual gross farm sales, higher acreage, and a smaller percentage being low income farms. Table 1 below provides a summary of the data presented above.

Table 1. Demographic characteristics of total sample $(n=385)$ compared with USDA agricultural census data for North Carolina (USDA, 1999).

\section{Variable description}

Mean age of farm owner or owner/operator

Mean farm acreage

Annual gross farm income frequencies by response category

Mean gross farm income

Gender - percentage male/female.

Racial breakdown:

White

Black or other races

Spanish, Hispanic or Latino

\section{Total Sample $\underline{(n=385)}$}

55 years

539 acres

Low $=28 \%$

Med $=25 \%$

High $=47 \%$

\$133K

Male $=88 \%$

Fem $=12 \%$

$96 \%$

$4 \%$

$0 \%$
USDA Agricultural Census for North Carolina 55 years

185 acres

Low $=67 \%$

Med $=13 \%$

High $=21 \%$ $\$ 155 \mathrm{~K}$

Male $=92 \%$

Fem $=8 \%$

$96 \%$

$4 \%$

$<1 \%$ 
The means and percentages of the independent variables are displayed in Table 2 on the following page. Intercorrelations shown in Appendix A between the independent variables ranged from $\mathrm{r}=0.1$ to $\mathrm{r}=$ .64, with no evidence of multicollinearity.

Table 2. Independent variable means and frequency percentages for total sample and by farm vehicle public road crash status, and chi square or t-test results for crash versus no crash group comparisons.

\begin{tabular}{|c|c|c|c|c|}
\hline$\underline{\mathbf{Q}}$ & $\underline{\text { Variable }}$ & $\begin{array}{c}\text { Total } \\
\text { Sample } \\
(\mathbf{n}=\mathbf{3 8 5})\end{array}$ & $\begin{array}{l}\text { Crash } \\
(\mathbf{n}=\mathbf{2 0 0})\end{array}$ & $\begin{array}{l}\text { No crash } \\
(n=185)\end{array}$ \\
\hline $6 \mathrm{~B}$ & $\begin{array}{l}\text { Age of youngest farm vehicle driver on public } \\
\text { roads (mean) }\end{array}$ & 33.6 & $31.1^{* *}$ & 36.4 \\
\hline 7B & $\begin{array}{l}\text { Age of oldest farm vehicle driver on public } \\
\text { roads (mean) }\end{array}$ & 60.5 & 59.6 & 61.5 \\
\hline $18 \mathrm{~B}$ & Hours drive on public roads (mean) & 13.6 & $16.0 * *$ & 11.0 \\
\hline $4 \mathrm{~J} 2$ & $\begin{array}{l}\text { Non-family hired farm help drive farm } \\
\text { vehicles on public roads (D - \%) }\end{array}$ & 46.7 & $76.5^{* *}$ & 24.0 \\
\hline nonenglish & Non-English speaking (D - \%) & 28.0 & $41.0 * *$ & 14.0 \\
\hline 52 & Farm injury history (mean) & 1.0 & $1.5 * *$ & 0.5 \\
\hline 28 & $\begin{array}{l}\text { Perception of danger of farm vehicle public } \\
\text { road driving (mean) }\end{array}$ & 3.0 & 3.0 & 3.0 \\
\hline didrev & $\begin{array}{l}\text { Farm vehicle public road crash preventive } \\
\text { actions taken (mean) }\end{array}$ & 0.8 & $0.9 * *$ & 0.7 \\
\hline oldest & $\begin{array}{l}\text { Oldest farm vehicle being driven on public } \\
\text { roads (mean) }\end{array}$ & 34.3 & 34.4 & 34.0 \\
\hline truckT & Drive trucks on public roads (D - \%) & 77.0 & $83.5^{* *}$ & 70.2 \\
\hline largeT & Drive large vehicles on public roads (D -\%) & 67.0 & $77.0 * *$ & 56.2 \\
\hline totaluse & $\begin{array}{l}\text { Total number and variety of non-farm vehicle } \\
\text { public road uses (mean) }\end{array}$ & 1.9 & $2.2^{* *}$ & 1.5 \\
\hline 12 & Traffic density **: & & & \\
\hline & - $\quad$ Low density (D - \%) & 19.7 & $13.0 * *$ & 27.0 \\
\hline & - $\quad$ Medium density (D - \%) & 55.3 & 54.0 & 56.5 \\
\hline & - $\quad$ High density (D - \%) & 24.9 & $30.5^{* *}$ & 18.9 \\
\hline 23 & Public road conflict (mean) & 3.0 & $3.2 * *$ & 2.7 \\
\hline 2 & Number of farm operations (mean) & 3.1 & $3.8 * *$ & 2.3 \\
\hline income & $\begin{array}{ll}\text { Gross farm income } * * \text { : } \\
\text { - } & \text { Low income }(<\$ 25 \mathrm{~K})(\mathrm{D}-\%) \\
\text { - } & \text { Medium income }(\$ 25 \mathrm{~K} \text { to } \$ 99 \mathrm{~K})(\mathrm{D}-\%) \\
\text { - } & \text { High income (\$100K or more) (D - \%) }\end{array}$ & $\begin{array}{l}28.3 \\
24.9 \\
46.7\end{array}$ & $\begin{array}{l}11.0 * * \\
24.0 \\
65.0 * *\end{array}$ & $\begin{array}{l}47.0 \\
25.9 \\
27.0\end{array}$ \\
\hline
\end{tabular}

Note: $\mathrm{X}^{2}(\mathrm{df}=1)$ or t-test $(\mathrm{df}=383)$ significant differences between crash and no-crash groups $* p<.05$, $* * p<.001$; D - \%: dichotomous variable response percentage. 


\section{Model and hypothesis testing}

The study's model tested the combined association of eighteen driver, vehicle, and public road and farm environmental characteristics with farm vehicle public road crash group membership. The model was significant with a likelihood ratio of $192.4(\mathrm{df}=18 ; p<.001 ;-2 \log$ likelihood intercept only $=533.1 ;-2$ log likelihood full model = 340.6).

Curvilinear relationships were posited for three independent variables: younger farm vehicle drivers, older farm vehicle drivers, and hours drive farm vehicles on public roads. None of the three posited curvilinear relationships were significant, however. Thus, the quadratic variables were excluded from the model presented here.

Logistic regression generated Wald $X^{2}$ statistics shown in Table 3 below were significant for the following driver, vehicle, and public road and farm environmental characteristics when controlling for all other independent variables in the model: age of youngest farm vehicle driver $\left(\mathrm{X}^{2}=5.57 ; p<.001\right)$; age of oldest farm vehicle driver $\left(\mathrm{X}^{2}=6.84 ; p<.001\right)$; non-family hired help drivers $\left(\mathrm{X}^{2}=22.20 ; p<.001\right)$; nonEnglish speaking help drivers $\left(\mathrm{X}^{2}=19.61 ; p<.001\right)$; farm injury history $\left(\mathrm{X}^{2}=8.96 ; p<.001\right)$; farm vehicle public road driving danger $\left(\mathrm{X}^{2}=7.44 ; p<.001\right)$; non-farm vehicle public road use $\left(\mathrm{X}^{2}=7.36 ; p<\right.$ $.001)$; public road driving conflict $\left(\mathrm{X}^{2}=10.61 ; p<.001\right)$; and low farm income $\left(\mathrm{X}^{2}=11.58 ; p<.001\right)$.

Odds ratio point estimates and Wald 95\% confidence limits indicate the following combination of driver, vehicle, and public road and farm environmental characteristics are associated with increased likelihood of farm vehicle public road crash group membership controlling for all other independent variables: non-English speaking help ( $\mathrm{OR}=4.61 ; \mathrm{CI}=2.34$ - 9.07); non-family hired help (OR = 4.32; CI $=2.35-7.96)$; public road driving conflict $(\mathrm{OR}=1.77 ; \mathrm{CI}=1.25-2.50)$, farm injury history $(\mathrm{OR}=1.34$; $\mathrm{CI}=1.10-1.63)$; non-farm vehicle public road use $(\mathrm{OR}=1.40 ; \mathrm{CI}=1.09-1.78)$; and, age of youngest farm vehicle driver $(\mathrm{OR}=1.02$; $\mathrm{CI}=1.01-1.04)$.

Three relationships were significant, however, in the opposite direction posited. Respondents reporting higher ages for oldest farm vehicle driver $(\mathrm{OR}=0.96$; $\mathrm{CI}=0.94-0.99)$ were less likely crash group members. Respondents reporting a higher perception of farm vehicle public road driving danger $(\mathrm{OR}=0.53 ; \mathrm{CI}=0.34-0.84)$ were less likely members of the farm vehicle public road crash group than respondents reporting lower levels. Respondents reporting low farm income $(\mathrm{OR}=0.26 ; \mathrm{CI}=0.12-0.57)$ 
were less likely members of the farm vehicle public road crash group than farms reporting medium farm income

Table 3. Logistic regression Wald statistic, odds ratio point estimates and confidence limits $(\mathrm{n}=385)$

\begin{tabular}{|c|c|c|c|}
\hline Variable & Wald $X^{2}$ & $\begin{array}{l}\text { Odds Ratio } \\
\text { Point } \\
\text { estimate }\end{array}$ & $\begin{array}{c}95 \% \text { Wald } \\
\text { confidence } \\
\text { limits }\end{array}$ \\
\hline Q6b Age of youngest driver & $\underline{5.57 *}$ & $\underline{1.02}$ & $\underline{1.01-1.04}$ \\
\hline Q7b Age of oldest driver & $6.84 * *$ & 0.96 & 0.94-0.99 \\
\hline Q18b Hours drive on public roads & 0.62 & 1.00 & $0.98-1.03$ \\
\hline Q4j2 Non-family hired help (D) & $\underline{22.20 * *}$ & $\underline{4.32}$ & $\underline{2.35-7.96}$ \\
\hline Q5 Non-English speaking help (D) & $\underline{19.61 * *}$ & $\underline{4.61}$ & $\underline{2.34-9.07}$ \\
\hline Q52 Farm injury history & $\underline{8.96 * *}$ & $\underline{1.34}$ & $\underline{1.10-1.63}$ \\
\hline Q28 Perception of danger & $7.44 * *$ & 0.53 & $0.34-0.84$ \\
\hline Q27 Preventive actions taken & 0.03 & 0.97 & $0.73-1.29$ \\
\hline Oldest farm vehicle & 0.77 & 1.01 & $0.98-1.03$ \\
\hline Farm trucks (D) & 2.27 & 1.67 & $0.85-3.26$ \\
\hline Q13 Large size farm vehicles (D) & 2.91 & 1.67 & $0.92-3.04$ \\
\hline Q11 Total non-farm public road use & $\underline{7.36 * *}$ & $\underline{1.40}$ & $\underline{1.09-1.78}$ \\
\hline $\begin{array}{ll}\text { Q12 } & \text { Low traffic density (D) } \\
\text { Q12 } & \text { High traffic density (D) }\end{array}$ & $\begin{array}{l}0.60 \\
0.82\end{array}$ & $\begin{array}{l}0.75 \\
1.38\end{array}$ & $\begin{array}{l}0.37-1.53 \\
0.68-2.80\end{array}$ \\
\hline$\underline{\text { Q23 Public road conflict }}$ & $\underline{10.61 * *}$ & $\underline{1.77}$ & $\underline{1.25-2.50}$ \\
\hline Q2 Number of farm operations & 0.59 & 1.02 & $0.95-1.10$ \\
\hline Q57 Low farm income $(D)$ & $11.58 * *$ & 0.26 & $0.12-0.57$ \\
\hline Q57 High farm income (D) & 0.56 & 1.29 & $0.66-2.50$ \\
\hline
\end{tabular}




\section{DISCUSSION}

The combined logistic regression model of 18 farm vehicle driver, farm and non-farm vehicle, and public road and farm environmental characteristics was significant for farm vehicle public road crash group membership differences. Six of the 18 driver, vehicle and environmental hypotheses tested with this model were supported, nine were not, and three were significant but in the opposite direction hypothesized.

Six independent variable hypotheses were supported. Four of those six were for farm vehicle driver characteristics, namely: age of youngest farm vehicle driver, non-family hired help driving farm vehicles on public roads; non-English speaking help driving farm vehicles on public roads; and, farm injury history. One supported hypothesis was for the non-farm vehicle characteristic, non-farm vehicle public road use. Another was for the public road environmental characteristic, farm vehicle public road driving conflict.

These finding suggest that farms reporting certain driver, vehicle and environmental characteristics are at increased risk for farm vehicle public road crash group membership. Specifically, farms reporting characteristics, such as, younger aged farm vehicle public road drivers, non-family and non-English speaking farm help driving farm vehicles on public roads, an injury history, increased number and variety of non-farm vehicles sharing public roads, and experiencing public road conflict, are at increased risk for crash group membership. These findings do not demonstrate whether or not these characteristics are also significant at the level of the individual driving the farm vehicle at the time of the crash.

The nine hypotheses not supported were: two farm vehicle driver characteristics (i.e., number of hours drive farm vehicles on public roads; and, crash preventive actions); all three farm vehicle characteristics (i.e., age of oldest farm vehicle; farm truck; large size farm vehicle); two public road environmental characteristics (i.e., low traffic density and high traffic density both as compared with medium traffic density); and, two farm environmental characteristics (i.e., number of farm operations, and, high farm income compared with medium farm income). All of these predictor variables had significant bivariate associations with crash status (except for age of oldest farm vehicle), but explained no unique variation in crash group membership in the full model. 
Three variables showed significant crash group differences but in the opposite direction hypothesized (i.e. negative instead of positive): two farm vehicle driver characteristics (i.e., age of oldest farm vehicle driver; and, perception of farm vehicle public road driving danger); and one farm environmental characteristic (i.e., low farm income compared with medium farm income). These findings suggest that farms employing older farm vehicle drivers, reporting low farm income, or a high perception of farm vehicle public road driving danger are associated with decreased risk of farm vehicle public road crash group membership.

These farm vehicle public road crash findings support the perspective that public road crashes are complex social phenomena (Batten, 2000). Driver, vehicle and environmental characteristics hypothesized in this study contributed to crash group membership differences, both independently and in combination.

Crash group membership associations are discussed for each variable in detail below by driver, vehicle and environmental characteristic groups. A figure showing these characteristic groups and the variables tested in this model is provided in Appendix A. Variables are highlighted based on their outcome (i.e., hypothesis confirmed = underlined; not confirmed = unchanged; and, opposite direction = italicized).

Several caveats should be kept in mind when considering these findings. First, driver, vehicle and environmental characteristics were measured in this study at the farm level not at the level of the individual driving the farm vehicle during the public road crash. Thus, the association between non-family and nonEnglish speaking farm vehicle drivers and crash group status cannot demonstrate whether or not these specific kinds of individual drivers are at greater risk for a crash. Second, driver, vehicle and environmental characteristics were measured at the time of the interview not at the time of the crash. Third, these study findings examine relationships that must be considered associational rather than causal.

Farm vehicle driver characteristics and crash group status

The four supported farm vehicle driver hypotheses (i.e., non-family hired help drivers, nonEnglish speaking help drivers, farm injury history, and youngest farm vehicle driver) will be discussed first. Next, the two hypotheses, which were significant but in the non-hypothesized direction, are reviewed (age of oldest farm vehicle driver, and perception of farm vehicle public road driving danger). Discussion of the 
two non-supported hypotheses (i.e., number of hours drive farm vehicles on public roads, and crash preventive actions taken) then follows.

Farms with respondents reporting non-family hired help $(\mathrm{OR}=4.32)$ or non English-speaking hired help $(\mathrm{OR}=4.61)$ driving farm vehicles on public roads were over 300 percent more probable crash group members than farms reporting no non-family or non-English speaking farm help driving. These results held true even when controlling for farm income, which was used as a proxy for farm size in this study. These two farm help status characteristics were the strongest predictors among all the independent variables in the model.

Farms reporting non-family hired help driving farm vehicles on public roads may be more likely crash group members than farms reporting only farm family help driving. There are several reasons why this may be so. To the extent that farms hire non-family hired help who are seasonal workers, the nonfamily hired help may be less familiar with the local public roadways and the specific farm equipment involved, even if they are generally experienced in driving farm vehicles on public roads. In addition, farm operators or owner/operators may be less systematic in reviewing safety issues concerning use of public roads with non-family hired help than they would be with family farm help. Family farm help may also have more farm vehicle driving skill and experience from growing up on the farm. To reiterate, non-family farm help driving farm vehicles on public roads was associated with crash status. However, these analyses do not indicate whether these specific types of drivers were involved in the farm vehicle public road crash. There may be characteristics of farms that report using non-family help to drive farm vehicles on public roads which contribute to increased risk for crash group membership.

Although strongly associated with the use of non-family farm help (phi coefficient $=.31$ ), farms reporting non-English speaking farm help driving farm vehicles on public roads were independently at increased risk for farm vehicle public road crash group membership. A number of factors may help explain these farm level findings. Language barriers and economic vulnerability may contribute to increased likelihood for crash group membership. If language barriers exist between farm operators or owner/operators and non-English speaking workers, farm vehicle safety information may not be effectively communicated (McCurdy et al., 2000; Murphy, 2003). Due to concerns regarding the vulnerability of their work status, non-English speaking workers may be more reluctant to raise perceived safety concerns with 
their employer in order to reduce their accident risk (Grieshop et al., 1996; McCurdy et al., 2000; Murphy, 2003). Again, these findings do not indicate whether non-English speaking farm help was driving the farm vehicle at the time of the crash. There may be characteristics of farms that report using non-English speaking help to drive farm vehicles on public roads which contribute to increased risk for crash group membership. Prospective studies are needed to further clarify whether these farm level findings can be replicated at the farm vehicle driver level, and to test whether there is a direct causal relationship between farm help status and crash group membership.

Several post hoc analyses were conducted to begin clarifying the association between farm help status and farm vehicle public road crash group membership. A chi square analysis compared the farm operator or owner/operator respondent age with crash group status, as well as with the number of farm help driving farm vehicles on public roads. Findings showed that younger aged farm operator or owner/operator respondents were at increased risk for crash group membership. In addition, younger age farm operator or owner/operator respondents were more likely to report having larger numbers of farm help driving farm vehicles on public roads. These findings suggest that farms reporting younger aged operators and larger numbers of non-family hired help driving farm vehicles on public roads are more likely crash group members. These characteristics may reflect the increase in corporate farms that has occurred over the last twenty years (USDA, 1999). Corporate farms may be run by younger farm operators or owner/operators and require increased numbers of non-family hired help to manage the large acreage farm production. Future analyses are warranted to better understand these suggested associations between farm type and crash status.

Reporting a history of farm injury resulting in absence from a day of work or receipt of medical treatment significantly increased the likelihood of crash group membership as hypothesized. A history of farm accidents and injuries could be indicative of inadequate equipment, or of a farm climate that is either high risk and/or inattentive to safety issues (Murphy, 2003). The farm operator or owner/operator history of injury was used as a proxy for the degree of injury on the farm across all farm help. The reporting of the operator or owner/operator's injury history alone increased the probability of farm crash group membership by 34 percent. Future assessments of farm injury history across a broader range of workers on each farm 
might provide a more accurate assessment of farm safety climate, and perhaps indicate an even stronger association with crash group membership.

Farms reporting lower ages for youngest farm vehicle driver on public roads were expected to be associated with crash group membership. This hypothesis was supported, but only marginally with a 2 percent increase in risk of farm vehicle public road crash group membership ( $\mathrm{OR}=1.02)$ when controlling for all other independent variables. This weak association may be due in part to the way in which the variable was constructed. Respondents were asked to report the "age of the youngest person driving farm vehicles on public roads.” The average age of the youngest driver was 33 years. Only $10 \%$ of the “youngest” drivers were 18 years or younger.

Post hoc analyses were conducted to help clarify the association between the age of the youngest farm vehicle driver and crash status. Young high-risk drivers are considered to be age 25 or under (Catalano, 2004). It was hypothesized, thus, that farms reporting youngest drivers either 25 years of age or youger would be at higher risk for crash group membership compared with farms reporting youngest drivers older than 25 years of age. The youngest farm vehicle driver age variable was dichotomized between high risk (i.e., 25 years old or younger) and non-high risk drivers (i.e., older than 25 years) to test the posited association. Findings showed significant group differences for young high risk drivers $\left(\mathrm{X}^{2}=\right.$ 5.09; $\mathrm{df}=1 ; p<.02$ ) compared with youngest drivers older than 25 years of age. Since logistic regression findings for age of youngest farm vehicle driver were only marginally significant, care should be taken when interpreting these results.

Farms reporting higher ages for oldest driver of farm vehicles on public roads were hypothesized to be associated with crash group membership. Contrary to expectations, farms reporting older ages for oldest farm vehicle driver on public roads were 4 percent less probable farm vehicle public road crash group members $(\mathrm{OR}=0.96)$. This unexpected, and albeit weak, relationship may be due in part to the variable construction. Respondents were asked to report the "age of the oldest person driving farm vehicles on public roads.” The average age of the oldest driver was 60 years, with $25 \%$ of the "oldest" drivers being 68 years or older. This sample may have contained fewer of the drivers whose age had impeded their driving performance and caused them to stop driving. Alternatively, these findings may suggest that farm 
vehicle drivers have crash prevention skills and experience acquired with age that help reduce the likelihood for farm vehicle public road crash group membership.

Older high-risk drivers are considered to be age 60 or older (Catalano, 2004). Post hoc analyses were conducted to test the hypothesis that older high-risk farm vehicle drivers (i.e., age 60 years or older) are at increased risk for crash group membership compared with ones younger than 60 years. Post hoc analysis findings supported the main study findings that farms reporting older individuals driving farm vehicles on public roads are at decreased probability for crash group membership. Since logistic regression findings for age of oldest farm vehicle driver were only marginally significant, care should be taken when interpreting these results.

Perceived danger of driving farm vehicles on public roads was hypothesized to be positively associated with crash group membership. Instead, perceived danger driving farm vehicles on public roads $(\mathrm{OR}=0.53)$ was significantly associated with reduced likelihood of crash group membership when controlling for all other independent variables. Farms reporting higher perceived farm vehicle public road driving danger were 47 percent less probable crash group members. It is possible that an increased perception of danger may cause farm vehicle drivers to be more defensive when traveling on public roads, thereby reducing their crash risk. Future research should examine prospectively how perceptions of farm vehicle public road driving danger are related to driving behavior and preventive actions taken, and, are associated with crash group membership.

Greater number of hours driving farm vehicles on public roads was not supported as a significant predictor of crash group membership in the combined logistic regression model. Post hoc analyses suggest this may be due to sharing variance with other significant predictors in the model, such as: use of nonfamily hired help drivers (phi coefficient $=.23 ; p<.01$ ); use of non-English speaking farm vehicle drivers (phi coefficient $=.10 ; p<.05$ ); and, public road driving conflict (point biserial coefficient $=.16 ; p<.05$ ).

Measurement limitations may also play a role here. Respondents were asked about the number of hours per week they personally drove farm vehicles on public roads. The assumption was that this would serve as a rough proxy for the level of public road driving exposure representative of that farm overall. To the extent that the farm respondents' hours of driving were not representative of exposure for the farm overall, one would expect a weaker relationship with crash status. 
The hypothesis that increased numbers of farm vehicle public road crash preventive actions taken would decrease the likelihood of farm vehicle public road crash group membership was not supported. Several explanations are plausible. First, crash preventive actions taken were measured by counting the number of responses to an open-ended question about actions taken to avoid a crash. This question may not have adequately captured the full range of what farmers actually did to prevent crashes. Second, individuals in the crash group who had not taken preventive actions before a crash occurred could have been prompted to do so after the occurrence of a farm vehicle public road crash. Such a pattern would obscure the actual causal relationship between preventive actions and probability of crash group membership. Third, crash prevention actions may be taken but the levels of farm vehicle public road driving conflict and competition for public road use may be overriding their positive contributions.

In summary, farms reporting younger farm vehicle drivers, as well as having non-family hired help and/or non-English speaking help drive farm vehicles on public roads, a farm injury history, or low perceived danger of driving farm vehicles on public roads are more probable crash group members. These findings suggest that farms with certain types of farm help and safety related characteristics are at increased risk for farm vehicle public road crash group membership.

\section{Vehicle characteristics and crash group status}

Only one of four vehicle hypotheses was supported, namely, for non-farm vehicle public road use. None of the three farm vehicle hypotheses were supported (i.e., age of farm vehicle; farm truck use; and large size farm vehicle use). Each hypothesis is discussed below, beginning with the non-farm vehicle characteristic, since its hypothesis was supported, followed by the non-supported farm vehicle characteristics.

The non-farm vehicle public road use variable was positively associated with farm vehicle public road crash group membership. Farm vehicles are now sharing once quiet, seldom traveled, two-lane rural roads with more and different types of non-farm vehicles (e.g., commuter traffic, construction traffic, school bus routes, etc). The greater the number and variety of public road uses, the more complex a social phenomenon farm vehicle public road use becomes. Thus, it is plausible that public roads used by other types of vehicles pose a greater crash risk for farm vehicle drivers. A greater number of public road uses 
was associated with a $40 \%$ increase in the probability of farm vehicle public road crash group membership. This contribution seems large, especially since the use of an open-ended question may not have adequately captured the full variation in public road use.

The age of the oldest farm vehicle driven on public roads was not associated with crash group membership at either the bivariate level or in the final logistic regression model. This was contrary to the expectation that older farm vehicles would be more likely crash group members. Two measurement problems may have contributed to the absence of a significant relationship. First, the survey question asked about the oldest farm vehicle driven, and was intended as a rough proxy for the age of the fleet of vehicles in use. To the extent that the oldest farm vehicle did not represent the overall farm safety level or that of the vehicles driven on public roads, one would not expect significant findings. Second, the age of a farm vehicle may not adequately reflect the presence or absence of safety features or a safety oriented farm environment.

Farm truck type was positively associated with farm vehicle public road crash group membership at the bivariate level but was not significant in the logistic regression model when controlling for other driver, vehicle and environmental characteristics.

Large size farm vehicle type was positively associated with crash group membership at the bivariate level but was not significant in the logistic regression model when controlling for other driver, vehicle and environmental characteristics.

\section{Environmental characteristics and crash group status}

Only one of four environmental hypotheses tested was supported, namely, for public road driving conflict. The two public road environmental hypotheses for traffic density (i.e., low traffic density and high traffic density compared with medium traffic density) were not supported. Two of three farm environmental hypotheses were also not supported (i.e., number of farm operations and high farm income compared with medium farm income). One farm environmental hypothesis (i.e., low farm income compared with medium farm income) was significant, but in the opposite direction posited (i.e., negative instead of positive). Each hypothesis is discussed below by importance of model contribution. 
The public road environmental hypothesis that farms reporting more public road driving conflict would be more likely crash group members was supported. Farm vehicles are sharing public roads with an increasing number and variety of non-farm vehicles. The conflicts that arise when sharing a limited resource like public roads can lead to a crash. Farms reporting more public road driving conflict were 77 percent more probable farm vehicle public road crash group members.

The public road environmental characteristic, traffic density, had two hypotheses, neither of which was supported. Traffic density was measured as low, medium, and high traffic density. The hypotheses that farms reporting low and high traffic density compared with medium traffic density would be more likely farm vehicle public road crash group members were not supported when controlling for other driver, vehicle and environmental characteristics. The traffic density relationships discussed below are in comparison to the referent group, medium traffic density.

Farms reporting low traffic density were less likely farm vehicle public road crash group members, rather than more likely as hypothesized. In addition, farms reporting low traffic density were negatively associated (rather than positively as hypothesized) with several driver, vehicle and environmental characteristics, namely: hours drive farm vehicles on public roads; farm injury history; large size farm vehicle use; and, non-farm vehicle public road use. These findings suggest that farms reporting low density traffic may drive less and thus experience less exposure to risk factors that might increase their probability of farm vehicle crash group membership.

The hypothesis for high traffic density was not supported when controlling for other driver, vehicle and environmental characteristics. High traffic density was positively correlated with crash group membership at the bivariate level, as well as with a number of driver, vehicle and environmental characteristics, namely: perceived farm vehicle public road driving danger; crash preventive actions taken; and non-farm vehicle public road use. One possible explanation for the findings is that high traffic density has an impact, at least in part, through increasing the perception of danger and prompting taking safety actions.

Two of the three farm environmental characteristic hypotheses were not supported: number of farm operations; and, high farm income compared with medium farm income. The hypothesis for low farm 
income was significant, but not in the posited direction (i.e., was negative rather than positive). Each farm environmental hypothesis is discussed below in order of importance of its contribution to the model.

The farm environmental hypothesis for number of farm operations was not supported. However, number of farm operations was positively associated with farm vehicle crash status at the bivariate level and with a number of driver, vehicle and environmental characteristics, i.e.: non-family hired help; farm truck use; large size farm vehicle use; non-farm vehicle public road use; and, high traffic density. These findings suggest that farms reporting higher numbers of farm operations may be at increased risk for a farm vehicle public road crash because they are more likely to use non-family hired help to drive farm vehicles on public roads, use farm trucks and large size farm vehicles, and share public roads with a large number and variety of non-farm vehicles.

The farm environmental hypothesis that farms reporting high farm income are more likely crash group members was not supported when controlling for other driver, vehicle and environmental characteristics in the model. Bivariate findings showed a positive association between high farm income and farm vehicle public road crash group membership. Thus, associations with other driver, vehicle and environmental characteristics may have contributed to the non-significant findings in the full model.

Farms reporting high farm income were associated with a number of driver, vehicle and environmental characteristics that suggest a large farm size, such as: number of hours drive farm vehicles on public roads; non-family hired help driving farm vehicles on public roads; non-English speaking help driving farm vehicles on public roads; farm injury history; farm truck and large size farm vehicle use; and number of farm operations. These findings suggest that effects of farm size may be seen as occurring through a number of driver, vehicle and environmental characteristics, reducing the effect of farm size as a variable in the full model.

One farm environmental characteristic, low farm income, was significantly associated with farm vehicle public road crash group membership controlling for all other driver, vehicle and environmental variables. But, the association was negative rather than positive as hypothesized. Farms reporting low farm income were posited to be more likely farm vehicle public road crash group members. Findings from this study suggest, however, that farms reporting low farm income are less likely crash group members than medium income farms. 
Low farm income was positively associated with age of youngest farm vehicle driver on public roads, suggesting small farms may be more likely to have younger individuals driving farm vehicles on public roads. Low farm income was negatively associated with: hours drive farm vehicles on public roads; non-family hired help; non-English speaking help; crash preventive actions taken; farm truck and large size farm vehicle use; non-farm vehicle public road use; public road conflict; and number of farm operations. These findings suggest that smaller size farms may have lower public road driving exposure as well as fewer resources that would allow more crash preventive actions to be taken. Measuring farm size using a farm income variable alone may not be as informative as a combination of driver, vehicle and environmental characteristics when studying farm vehicle public road crash group membership differences.

\section{Study limitations}

This study had a number of limitations, in particular, ones pertaining to: recall accuracy and measurement time periods; survey question design and measurement; the level of analysis; and, sampling bias. Each limitation is addressed below.

Measurement time periods. Crash cases were considered eligible for the study if they occurred from 1992 through 2003. Since the occurrence of farm vehicle public road crashes is such a rare event, a longer time period was chosen in order to capture a sufficient number of cases. Case and control respondents were asked the same questions about current environmental, vehicle and driver characteristics (e.g., traffic density, preventive actions taken, and so on).

Challenges are presented by cases in which crashes occurred some time ago. Accuracy of recall would be compromised if respondents were asked to describe environmental, vehicle, and driver characteristics at the time of a distant crash. For this reason, questions were asked about current conditions, with the assumption that these would, for the most part, be indicative of prior conditions. If these conditions had actually changed since the crash, the actual relationships between predictor variables and case-control status would be obscured.

Survey question and design. There are several potential weaknesses with regard to the validity of the instruments used in this study. First, the respondent was asked to describe characteristics of the farm and /or farm environment (e.g., road conditions, age of drivers, ands so on). There was no independent 
verification of the respondent's responses. Second, a number of variables used in this study were measured using single item closed and open-ended questions. Further validation and testing of measures may result in stronger findings.

Level of analysis. The thrust of this study was to examine how driver, vehicle and environmental characteristics at the farm level related to crash group status. The respondent was asked to describe several circumstances (e.g., average number of hours spent driving farm vehicle on a public road, injury history, and so on) with himself/herself as the referent point. The assumption was that respondent responses would serve as an approximate measure of these characteristics for the farm overall. To the extent that the operator or owner/operator's responses were atypical of the farm overall, use of these measures would obscure actual relationships.

Sampling bias: Two possible limitations of the study involve potential bias in construction of the sample and in the self-selection of respondents.

First, an USDA agricultural program database for North Carolina resident farm operators or owner/operators was used to generate the sampling frame for this study. Comparison of the study sample demographic profile with the North Carolina agricultural census profile in Table $\mathbf{1}$ indicated that the study sample had fewer small size farms, higher mean farm acreage, and reported lower mean gross farm income. Thus, these findings suggest a potential sampling bias. This raises questions about the generalizability of the study to the total population of North Carolina farmers. A comparison of farm vehicle driver age and percentage of crashes by month for this study with those of North Carolina crash report data (Hughes et al., 2000), however, suggests that the study sample is comparable to North Carolina farmers reporting a farm vehicle public road crash. Therefore, these findings suggest that although the USDA agricultural program database may have provided a biased sampling frame, crash case data comparisons suggest the study sample is reasonably representative of North Carolina farmers who drive farm vehicles on public roads and are involved in a crash.

Second, as noted in earlier, approximately 22 percent of calls were placed to numbers that were either out of service $(n=1,807)$, no longer where a farmer lived $(n=683)$, or could not be contacted $(n=$ 807). It is undetermined how many of these "unscreened" phone numbers actually represent nonidentified eligible participants. It is also unclear to what extent non-identified eligible participants might be 
different from those farm owners or owner / operators that were successfully screened. Thus, there may be bias in the individuals successfully screened in this study.

\section{Implications for future interventions}

Non-family hired farm help status had the greatest impact on likelihood of farm vehicle public road crash group membership of all eighteen driver, vehicle and environmental characteristics in the logistic regression model. The trend toward larger size farms requiring more farm help is likely to continue. So, the demand for non-family hired farm help is likely to increase as well in the future. Agriculture has historically drawn its non-family hired labor force from non-English speaking countries such as Mexico, Central America and the Caribbean. Non-family hired help, in particular non-English speaking farm help, may have less experience and skill competencies with driving farm vehicles on public roads. Alternatively, farms hiring larger numbers of non-family hired help may have less invested in supervising safety procedures. Future intervention research should identify farm and farm help characteristics that contribute to increased farm vehicle public road crash risk. Intervention research should determine whether farm vehicle driver licensing, training, testing and monitoring programs would be effective and cost efficient in reducing the risk for farm vehicle public road crash group membership.

Farms were taking a number of crash preventive actions to help reduce their risk of farm vehicle public road crash group membership. Crash preventive actions taken were, however, not significantly associated with decreased risk of farm vehicle public road crash group membership when controlling for all other variables as hypothesized. Crash preventive actions were positively associated though with farm truck, large size farm vehicle and non-farm vehicle public road use, high traffic density, and public road conflict. Thus, research should assess existing and future crash prevention interventions to determine what preventive actions taken individually or in combination best reduce the risk of farm vehicle public road crash.

Past farm vehicle public road crash preventive actions have focused primarily on the farm vehicle driver and the farm vehicle (Costello et al., 2003) rather than taking a combined driver, vehicle and public road environmental approach. Future farm vehicle public road crash reduction interventions should consider a combined approach that may require changes to the public road infrastructure if the primarily 
driver and vehicle focused crash preventive actions alone prove ineffective against increasing public road use competition and public road driving conflict, as suggested by these findings.

\section{Conclusion}

Public road crashes are complex social phenomena (Batten, 2000). Findings from this study support that perspective. Eighteen driver, vehicle and environmental characteristics were tested in a combined logistic model. Six farm vehicle driver, one non-farm vehicle, and one public road environmental characteristic were associated with increased likelihood of farm vehicle public road crash group membership. Two farm vehicle driver characteristics and one farm environmental characteristic reduced the likelihood of crash group membership.

Farms reporting non-family hired help and non-English speaking help driving farm vehicles on public roads were more probable crash group members. The trend toward larger, corporate type farms will most likely increase the demand for non-family hired help, in particular non-English speaking help, to drive farm vehicles on public roads.

Farm injury history and crash status findings suggest farm safety is associated with farm vehicle public road crash group membership. Non-family hired help, in particular non-English speaking help, may already be at increased accident risk because they may not have the same level of safety training, skill and experience as family farm help. Youngest farm vehicle drivers may also be at higher crash risk, due to a posited lack of driving skill and experience. Findings suggest an unsafe work environment, as measured by farm injury history reporting, further increases the probability for crash group membership.

Sharing public roads with more non-farm vehicles and experiencing public road conflict were associated with increased likelihood of farm vehicle public road crash group membership. The demand for public road use in North Carolina by a greater number and variety of non-farm vehicles will most likely continue in the future. And, North Carolina will most likely continue to be an important agricultural state. Thus, it is unlikely that farm vehicle public road crash risk will decrease without thoughtful intervention designed to reduce the conflict arising from sharing a limited resource, such as public roads.

Past farm vehicle crash preventive efforts focused mainly on the farm vehicle and driver and only to a limited degree on the public road environment and how it is shared. This combined analysis was able 
to show, that, although farms may be aware of the danger of driving farm vehicles on public roads and are taking crash preventive actions, the level of competition for public road use and the resulting public road conflict may be outweighing those preventive efforts, especially when farms report potentially less skilled and experienced individuals driving farm vehicles on public roads. Farm vehicle public road crash prevention research and intervention efforts should take into consideration combined associations of driver, vehicle and environmental characteristics with crash group membership to ensure more comprehensive and inclusive planning and assessment of farm vehicle public road crash prevention programs, rather than focusing primarily on the farm vehicle and the farm vehicle driver.

This study was able to build on existing findings and contribute additional insights regarding risk factors for farm vehicle public road crash group membership. Farm vehicle driver skill and experience, a safe farm work environment, and the characteristics of public road sharing with non-farm vehicles were most strongly associated with increased crash status probability. Yet, much is still left to clarify. Future analyses and research models should build on these findings by including other driver, vehicle and environmental characteristics as predictors of farm vehicle public road crash group membership, as well as examine characteristics for possible identification of high risk subgroups or clusters. 


\section{REFERENCES}

American Trucking Associations. 2000. Sharing the road with farm equipment. SafetyNet. [Online]. Available at: www.truckline.com/safetynet/highway/sharing farm_equipment.htm.

Batten, D.F. Safety and collective behavior on congested traffic networks. In von Holst, H., A. Nygren \& A. E. Andersson (Eds.) Transportation, Traffic Safety and Health: man and machine. Berlin, Germany: Springer-Verlag; 2000.

Catalano, J. 2004. Allstate Insurance Representative, Raleigh, NC.

Costello, T., Schulman M. \& R. Luginbuhl. 2003. Understanding the public health impacts of farm vehicle public road crashes in North Carolina. Journal of Agricultural Safety and Health. Vol. 9(1): 19-32.

Costello, T. \& M. Schulman. 2001. Farm vehicle public road safety. Unpublished paper prepared for Transportation Human Factors course. North Carolina State University, Raleigh, NC.

Costello, T. \& Wogalter, M. (2003). Driver Attitudes, Beliefs and Reported Behavior Associated with Sharing Public Roads with Farm Vehicles. Proceedings of the HFES $47^{\text {th }}$ Annual Meeting.

Doss, H. J. \& R. G. Pfister. 1972. Nature and extent of farm machinery use in relation to frequency of accidents in Michigan and Ohio. East Lansing, Mich.: Michigan State University, Agricultural Engineering Department.

Geller, E. 2001. The psychology of safety handbook. Boca Raton, FL: CRC Press LLC.

Gerberich, S., L. Robertson, R. Gibson, \& C. Reiner. 1996. An epidemiological study of roadway fatalities related to farm vehicles: United States, 1996. J. Occup. and Environ. Medicine 38(11): 11351140.

Glascock, L. A., T.L. Bean, R.K. Woo, T. G. Carpenter, \& R. G. Holmes. 1995. A summary of roadway accidents involving agricultural machinery. Journal of Agricultural Safety and Health. Vol. 1 (2): 93104.

Grieshop, J., M. Stiles \& N. Villanueva. 1996. Prevention and Resiliency: A cross cultural view of farmworkers' and farmers' beliefs about work safety. Human Organization. Vol. 55 (1): pp. 25-32.

Lacy, J., W. Hunter \& H. Huang. 2001. A study of farm vehicle crashes in North Carolina. Chapel Hill, NC: University of North Carolina Chapel Hill, Highway Safety Research Center.

Lakshmanan, T. R. Traffic safety and the demographic transition. In von Holst, H., A. Nygren \& A. E. Andersson (Eds.) Transportation, Traffic Safety and Health: man and machine. Berlin, Germany: Springer-Verlag; 2000.

Laughery, K.R. \& A. Hammond. 1999. Overview. In Wogalter, M.S., D.M. DeJoy \& K.R. Laughery (Eds). 1999. Warnings and risk communication. Philadelphia, PA: Taylor \& Francis, Inc.

Luginbuhl, R.C., V.C. Jones, \& R.L. Langley. 2003. Farmer's perceptions and concerns: the risks of driving farm vehicles on rural roadways in North Carolina. Journal of Agricultural Safety and Health. Vol. 9(4): 327-348.

Mason, G. 2003. Telephone conversation regarding farm vehicle speed and public road use. Knightdale, NC: The Tractor Place, Inc. 
McCurdy, S.A. \& D.J. Carroll. 2000. Agricultural injury. American Journal of Industrial Medicine. Vol. 38: $463-480$.

Murphy, D.J. 2003. Chapter 1: Reasons and motivations for conducting this review. Looking beneath the surface of agricultural safety and health. St. Joseph, MI: American Society of Agricultural Engineers.

NCDOL. 1999. Fifth Annual Gold Star Luncheons: Fixing Grower's Sights on Rural Highway Safety. The Cultivator 15 (May): 1-2.

NCOSPL. 1997. Population growth 1980-1990. Raleigh, NC: Office of State Planning. Available at: www.ospl.state.nc.us/demog/estgr0.htm.

NCOSPL. 2000. Population growth 1990-1999. Raleigh, NC: Office of State Planning. Available at: www.ospl.state.nc.us/demog/c99estp.htm.

O’Neill, B. \& D. Mohan. 2002. Reducing motor vehicle crash deaths and injuries in newly motorizing countries. British Medical Journal. 321 (11): 1142-1145.

Pickett, W., Chipman, M. L., Brison, R. J. \& Holness, D. L. 1996. Medications as risk factors for farm injury. Accident Analysis and Prevention, 28 (4): 453-462.

Tabachnick, B. G. \& L. S. Fidell. 2001. Using multivariate statistics. Needham Heights, MA: Allyn \& Bacon.

Van Holst, H. 2000. Introduction. In von Holst, H., A. Nygren \& A. E. Andersson (Eds.) Transportation, Traffic Safety and Health: man and machine. Berlin, Germany: Springer-Verlag. 


\section{APPENDIX A}

Additional Data Tables, Figures and Graphs 


\begin{tabular}{|l|}
\hline \multicolumn{1}{|c|}{ Driver } \\
\hline Farm Vehicle Driver \\
Characteristics \\
Age of driver: \\
• $\quad$ Youngest driver \\
Oldest driver. \\
Hours per week drive on \\
public roads during busiest \\
months (exposure). \\
Farm help driving farm \\
vehicles on public roads: \\
$\bullet \quad$ Hired help \\
Non-English speaking \\
help. \\
Safety behaviors: \\
$\bullet \quad$ Farming injury history. \\
Perception of farm \\
vehicle public road \\
danger. \\
Farm vehicle public \\
road crash preventive \\
actions.
\end{tabular}

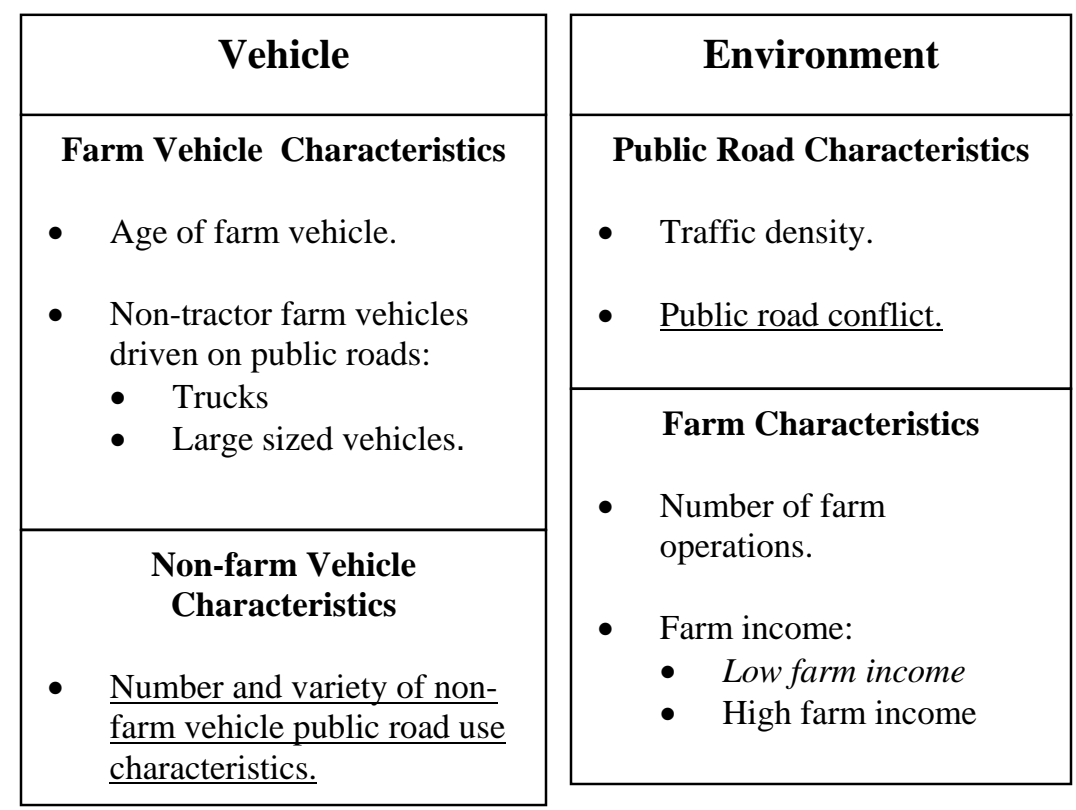

Figure 1. Research model - driver, vehicle, and environmental characteristics posited to be associated with farm vehicle public road crash group membership.

Note: confirmed hypotheses are underlined, non-confirmed are unchanged, opposite are italicized. 
Table 3. Intercorrelations for farm vehicle public road crashes and independent variables $(\mathrm{n}=385)$

\begin{tabular}{|c|c|c|c|c|c|c|c|c|c|c|c|c|}
\hline & measure & $\underline{1}$ & $\underline{2}$ & $\underline{3}$ & $\underline{4}$ & $\underline{5}$ & $\underline{6}$ & $\underline{7}$ & $\underline{8}$ & $\underline{9}$ & $\underline{10}$ & $\underline{11}$ \\
\hline 1 & $\overline{\text { Crash }}$ & & & & & & & & & & & \\
\hline 2 & Youngest & $-.16^{* *}$ & - & & & & & & & & & \\
\hline 3 & Oldest & -.08 & $.20 * *$ & - & & & & & & & & \\
\hline 4 & Hours drive & $.18^{* *}$ & $-.13 * *$ & .09 & - & & & & & & & \\
\hline 5 & Hired help $\wedge$ & $.43^{* *}$ & $-.32 * *$ & .02 & $.23^{* *}$ & - & & & & & & \\
\hline 6 & $\begin{array}{l}\text { Non-English } \\
\text { help } \wedge\end{array}$ & $.29 * *$ & $-.25 * *$ & -.05 & $.10^{*}$ & $.31^{* *}$ & - & & & & & \\
\hline 7 & Farm injury & $.21^{* *}$ & -.07 & .01 & .08 & .07 & -.01 & - & & & & \\
\hline 8 & $\begin{array}{l}\text { Perception of } \\
\text { danger }\end{array}$ & .04 & -.01 & .02 & .05 & .06 & $.17^{* *}$ & $.17 * *$ & - & & & \\
\hline 9 & $\begin{array}{l}\text { Preventive } \\
\text { actions }\end{array}$ & $.11^{*}$ & -.04 & -.01 & .02 & .05 & -.01 & .09 & .05 & - & & \\
\hline 10 & Oldest vehicle & .01 & -.01 & -.06 & -.01 & -.05 & -.03 & .09 & $.11^{*}$ & .04 & - & \\
\hline 11 & Farm truck $\wedge$ & $.15^{* *}$ & $-.15^{* *}$ & -.02 & .07 & $.13^{* *}$ & .01 & .05 & .01 & $.14^{* *}$ & .09 & - \\
\hline 12 & Large vehicle $\wedge$ & $.22 * *$ & $-.11^{*}$ & .04 & .06 & $.10^{*}$ & .03 & $.14^{* *}$ & .09 & $.17^{* *}$ & $.11^{*}$ & .06 \\
\hline 13 & Non-fv use & $.24 * *$ & $-.11^{*}$ & -.01 & $.10^{*}$ & $.11^{*}$ & .04 & .08 & $.11^{*}$ & $.32 * *$ & .01 & $.15^{* *}$ \\
\hline 14 & Low density $\wedge$ & $-.17 * *$ & .04 & -.03 & $-.11^{*}$ & -.08 & -.10 & $-.11^{*}$ & $-.15^{* *}$ & -.04 & -.02 & -.01 \\
\hline 15 & Med density $\wedge$ & .02 & -.05 & -.05 & .05 & .02 & .06 & .01 & -.04 & -.06 & .01 & -.01 \\
\hline 16 & High density ^ & $.13^{* *}$ & .02 & .08 & .03 & .04 & .02 & .09 & $.19 * *$ & $.11^{*}$ & .02 & .01 \\
\hline 17 & PR conflict & $.30 * *$ & -.06 & .06 & $.16^{* *}$ & $.14^{* *}$ & .05 & $.25^{* *}$ & $.27 * *$ & $.20 * *$ & .07 & .09 \\
\hline 18 & \# farm ops & $.17^{* *}$ & $-.12^{*}$ & .05 & .09 & $.15^{* *}$ & .09 & .04 & .06 & -.01 & -.02 & $.10^{*}$ \\
\hline 19 & Low income $\wedge$ & $-.39 * *$ & $.19^{* *}$ & .01 & $-.16^{* *}$ & $-.34 * *$ & $-.19 * *$ & -.07 & -.09 & $-.12 *$ & .04 & $-.12 *$ \\
\hline 20 & Med income $\wedge$ & -.02 & .03 & -.03 & .01 & $-.15^{* *}$ & -.02 & -.04 & -.01 & .03 & .05 & -.02 \\
\hline 21 & High income $\wedge$ & $.38 * *$ & $-.21 * *$ & .02 & $.14^{* *}$ & $.44^{*}$ & $.20 * *$ & $.10^{*}$ & .09 & .08 & -.08 & $.13^{* *}$ \\
\hline
\end{tabular}

Table 3 (cont.). Intercorrelations for farm vehicle public road crashes and independent variables

\begin{tabular}{|c|c|c|c|c|c|c|c|c|c|c|}
\hline & measure & $\underline{12}$ & $\underline{13}$ & $\underline{14}$ & $\underline{15}$ & $\underline{16}$ & $\underline{17}$ & $\underline{18}$ & $\underline{19}$ & $\underline{20}$ \\
\hline 12 & Large vehicle $\wedge$ & - & & & & & & & & \\
\hline 13 & Non-fv use & $.14^{* *}$ & - & & & & & & & \\
\hline 14 & Low density $\wedge$ & $-.17 * *$ & $-.17^{* *}$ & - & & & & & & \\
\hline 15 & Med density $\wedge$ & .08 & -.03 & $-.55^{* *}$ & - & & & & & \\
\hline 16 & High density $\wedge$ & .07 & $.20^{* *}$ & $-.28 * *$ & $-.64 * *$ & - & & & & \\
\hline 17 & PR conflict & $.20^{* *}$ & $.22 * *$ & $-.29 * *$ & -.07 & $.27 * *$ & - & & & \\
\hline 18 & \# farm ops & $.16^{* *}$ & $.13^{* *}$ & -.07 & -.03 & $.11^{*}$ & .07 & - & & \\
\hline 19 & Low income $\wedge$ & $-.23 * *$ & $-.14^{* *}$ & .02 & -.01 & -.02 & $-.16^{* *}$ & $-.20 * *$ & - & \\
\hline 20 & Med income $\wedge$ & .01 & -.07 & .04 & .04 & -.09 & -.03 & -.08 & $-.36 * *$ & \\
\hline 21 & High income $\wedge$ & $.22^{* *}$ & $.18^{* *}$ & -.05 & -.02 & .08 & $.17 * *$ & $.26^{* *}$ & $-.58 * *$ & $-.54^{* *}$ \\
\hline
\end{tabular}

Note: farm vehicle public road crashes coded as $1=$ no crash; $2=$ crash; dichotomous variables coded as $1=$ no response, $2=$ yes response; ${ }^{*} p<.05 ; * * p<.001 . \wedge$ symbol represents dichotomous phi coefficient correlations. 


\section{APPENDIX B}

List of Abbreviations 


\section{LIST OF ABBREVIATIONS}

ANSI

ASAE

CDC

EMS

FARS

mph

MUTCD

NCDOT

OSHA

ROPS

SMV

VMT
American National Standard Institute.

American Society of Agricultural Engineers.

Centers for Disease Control and Prevention.

Emergency medical system.

Federal Accident Reporting System.

Miles per hour.

Manual on Uniform Traffic Control Devices. Published by the U.S. Department of Transportation, Federal Highway Administration.

North Carolina Department of Transportation.

Occupational Safety and Health Administration.

Rollover protection structures.

Slow-moving vehicle. Defined as a vehicle that travels less than $25 \mathrm{mph}$ on public roads.

Vehicle miles traveled. 


\section{APPENDIX C}

Farm Vehicle Public Road Crash Study Press Release 
Michael Schulman, Ph.D.

Press Release

Department of Sociology

North Carolina State University

Raleigh, North Carolina 27695

(919) 515-9016

michael_schulman@ncsu.edu.

\section{Farmers' Concerns about Farm Vehicle Public Road Crashes}

Farmers who have earned the Distinction of “Gold Star Growers” from North Carolina Department of Labor's (NCDOL) Division of Agricultural Safety and Health, identified farm vehicle public road crashes as one of their top safety concerns several years ago.

With the increase in urban development and influx of new residents to the state, once quiet country roads used primarily for farm transportation are now being shared with commuters, tourists, and transport vehicles. Sharing North Carolina public roads creates challenges both for farmers trying to plant and harvest crops, and others who are passing through a farming area to reach their destination. A survey conducted in 1999 by NCDOL Division of Agricultural Safety and Health, in conjunction with North Carolina State University, showed this to be a common concern of many farmers participating in the Gold Star Grower program. Over 97 percent of the approximately 600 Gold Star Growers responding to the survey thought driving farm vehicles on North Carolina public roads to be more dangerous than five years prior (i.e., since 1995) and more than 79 percent felt unsafe driving farm vehicles on public roads. A new study being conducted between January and March of 2003 aims to collect information to understand farmers’ concerns about using their farm vehicles on public roads.

On average 300-farm vehicle public road crashes occur annually in North Carolina. Examination of publicly available information from the North Carolina Department of Motor Vehicles (NCDMV) reveals that the combination of motorists' desire to speed and the limited speed at which farm vehicles can travel and maneuver was cited as a cause in over 30 percent of farm vehicle related public road crashes reported between 1995 and 1999. NCDMV crash reports also show improper passing (17 percent of nonfarm vehicle operator cited crashes), unsafe vehicle movement (34 percent of farm tractor operator cited crashes), and failure to yield right of way (13.7 percent of farm tractor operator cited crashes) as contributing factors to these crashes. 
The NC DOL Division of Agricultural Safety and Health and its advisory group, The North Carolina Agricultural Safety Council, have placed a high priority on addressing this safety concern. The Division has sponsored Slow Moving Vehicle (SMV) Signage Giveaway Programs for farmers and has provided public road safety education and training in conjunction with NCDMV and the North Carolina Growers Association. These are important steps in addressing this critical public road safety issue. More information is needed, however, to develop effective policy and safety recommendations for public road transportation and safety interventions that will make North Carolina public roads safe for farmers and motorists alike.

Researchers associated with the NC Agromedicine Institute, a partnership of NC State University, East Carolina University, and NC A\&T State University, and the Southern Coastal Agromedicine Center will be conducting a study to better understand the circumstances that contribute to farm vehicle public road crashes. Trained interviewers from the NCSU Center for Urban Affairs beginning January 2003 will conduct a confidential telephone survey of North Carolina farmers. The survey will ask farmers about: the characteristics of their farming operations; the public roads utilized for farming; their experiences driving and transporting farm vehicles on North Carolina public roads; and, recommendations and insights farmers have regarding causes and solutions. Questions or requests for information regarding the study should be directed to Michael Schulman, Ph.D., Department of Sociology, North Carolina State University, Raleigh, North Carolina, 27695, (919) 515-9016, michael_schulman@ncsu.edu.

\section{ENDS}




\section{APPENDIX D}

Farm Vehicle Public Road Crash Telephone Survey Informed Consent Script 


\section{Farm Vehicle Public Road Crash Telephone Survey Informed Consent Script}

Your responses will be kept confidential. We will not identify individuals when we report results. I want to assure you that no one will be able to identify you personally from our reports. There are no known risks to participating in this interview. Although there are no direct benefits to you, your responses will help us to gain a better understanding of farm vehicle public road safety, and ways to address this public health and safety concern. Your participation is voluntary and your willingness to answer questions is taken as consent to participate. You may choose not to answer any or all of the following questions.

If you have any questions about this study, you can direct them to Dr. Michael Schulman of the North Carolina State University Sociology Department, Box 8107, Raleigh, NC 27695-8107, at (919) 515-9016. You may also direct any questions about the way this survey was administered or your rights as a research

subject to Debra Paxton, North Carolina State University, at (919) 515-7200. Please let me know at the end of the interview if you have any concerns, and I will provide you with these names and numbers again. You are not required to give your name if you are filing a complaint. 


\section{APPENDIX E}

Farm Vehicle Public Road Crash Telephone Survey and Codebook 


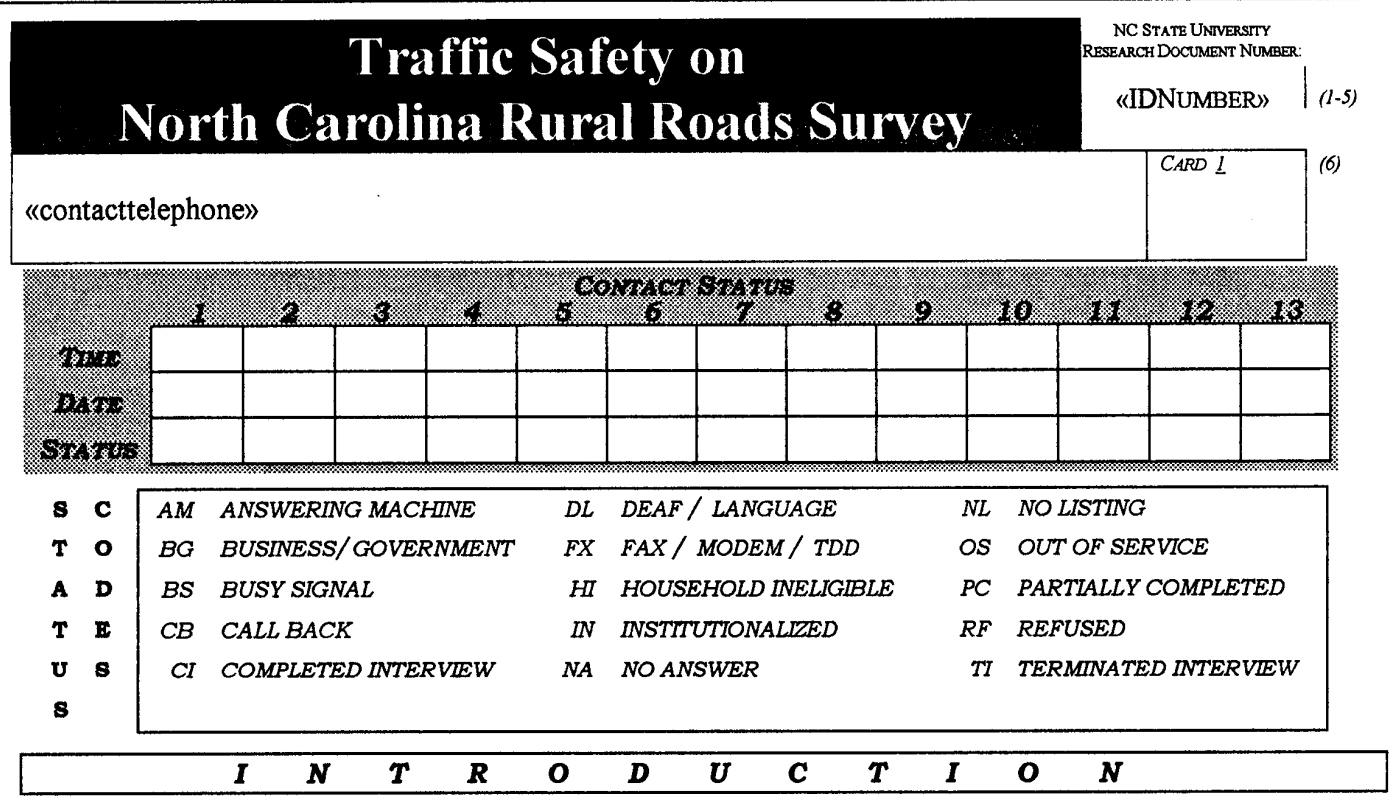

Hello, my name is

I've been asked by researchers at North Carolina State University to talk with farmers about farm vehicle public road safety. May I speak with the primary person involved with farming?

$$
\begin{aligned}
& \text { IF NON-FARMER, CODE "HI" - HOUSEHOLD INELIGIBLE, } \\
& \text { THANK RESPONDENT AND DISCONTINUE INTERVIEW. }
\end{aligned}
$$

Your number was chosen at random from a list of all North Carolina farmers who drive farm vehicles on North Carolina public roads. First I need to confirm, have I reached (VERIFY PHONE NUMBER)?

A. Are you 18 years of age or older?

\section{IF NOT 18 OR OLDER, REQUEST ANOTHER HOUSEHOLD MEMBER IF 18 OR OLDER, CONTINUE INTERVIEW.}

B. Do you, your family members, or your employees drive or transport farm tractors or other farm equipment on public roads?

$$
\begin{aligned}
& \text { Yes [SKIP TO QD] } \\
& \text { No [ConTINUE] }
\end{aligned}
$$

C. [IF NO:] Why do you not drive your farm tractors or equipment on public roads? [DO NOT READ LIST] [CIRCLE ALL THAT APPLY]

My land is all together so I don't have to use public roads. ....................................................

Someone else besides my employees or me does the driving. .........................................................

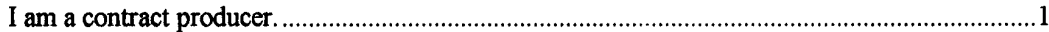

I am not actively involved in farming................................................................................

I am retired [ED. CODE] .......

THANK THE INDIVIDUAL FOR THEIR TIME AND TERMINATE THE INTERVIEW.

D. Have you or anyone helping you with farm work been involved in a farm vehicle crash on a public road in the last 10 years (since 1992)? 


\begin{tabular}{|c|c|c|c|c|}
\hline 1. & \multicolumn{2}{|c|}{$\begin{array}{l}\text { What is your primary role in the farming operation? } \\
\text { [CIRCLE ONE RESPONSE] }\end{array}$} & 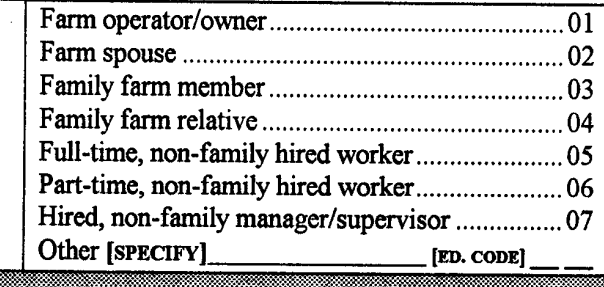 & \\
\hline 2. & \multicolumn{2}{|l|}{ How many farm operations do you own or manage? } & Number of farm operations ..................................... & \\
\hline 3. & \multicolumn{2}{|c|}{$\begin{array}{l}\text { How many individuals help you with farm work } \\
\text { throughout the growing season? [INCLUDE FULL AND } \\
\text { PART-TIME SEASONAL HELP, FAMILY MEMBERS } \\
\text { (INCLUDING CHILDREN AND TEENS), RELATIVES, FRIENDS, } \\
\text { HIRED EMPLOYEES/MANAGERS, ETC.] }\end{array}$} & Number of individuals.... & \\
\hline \multirow[t]{13}{*}{4.} & \multicolumn{3}{|c|}{ Who drives your farm vehicles on the farm? How about on public roads? [CIRCLE ALL THAT APPLY] } & \\
\hline & 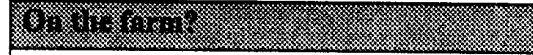 & & 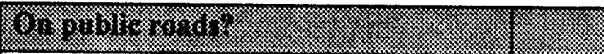 & \\
\hline & 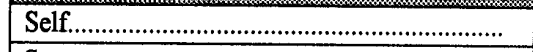 & 1 & 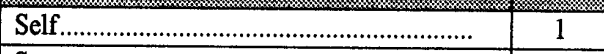 & 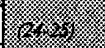 \\
\hline & 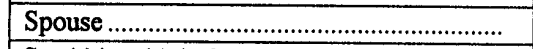 & 1 & Spouse & 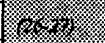 \\
\hline & Son(s)/son(s)-in-law........................................ & 1 & 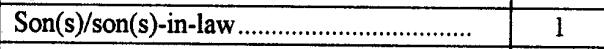 & (2.8.28 \\
\hline & Daughter(s)/daughter(s)-in-law ..................... & 1 & Daughter(s)/daughter(s)-in-law...................... & 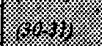 \\
\hline & Father/father-in-law ........................................... & 1 & Father/father-in-law.................................... & 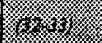 \\
\hline & Brother(s)/brother(s)-in-law .......................... & 1 & Brother/brother(s)-in-law .............................. & 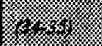 \\
\hline & Sister(s)/sister(s)-in-law................................... & 1 & Sister(s)/sister(s)-in-law ............................ & 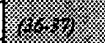 \\
\hline & Cousins, uncles, aunts, nieces, nephews, etc. & 1 & Cousins, uncles, aunts, nieces, nephews, dc & 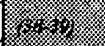 \\
\hline & 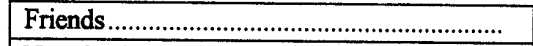 & 1 & Friends ……………………………………... & 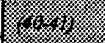 \\
\hline & Non-family hired employees ........................... & 1 & Non-family hired employees............................ & \\
\hline & Othet [SPECIFY] & & Other [SPECIFY] & 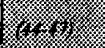 \\
\hline 5. & \multicolumn{2}{|c|}{$\begin{array}{l}\text { How many of those individuals helping you drive farm } \\
\text { vehicles speak another language at work besides } \\
\text { English? }\end{array}$} & Number of individuals ............................. & 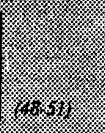 \\
\hline & \multicolumn{2}{|c|}{$\begin{array}{l}\text { What is the age of the youngest person driving farm } \\
\text { vehicles on the farm? How about driving farm vehicles } \\
\text { on public roads? }\end{array}$} & $\begin{array}{l}\text { On the farm } \\
\text { On public roads }\end{array}$ & : \\
\hline & \multicolumn{2}{|c|}{$\begin{array}{l}\text { What is the age of the oldest person driving farm } \\
\text { vehicles on the farm? How about driving farm vehicles } \\
\text { on public roads? }\end{array}$} & $\begin{array}{l}\text { On the farm. } \\
\text { On public roads...................................... age }\end{array}$ & (18. \\
\hline & \multicolumn{2}{|c|}{$\begin{array}{l}\text { How often do you drive farm vehicles on public roads? } \\
\text { Would you say ...? [READ RESPONSES] }\end{array}$} & $\begin{array}{l}\text { Seldom } \\
\text { Sometimes } \\
\text { Most of the time, or } \\
\text { All of the time }\end{array}$ & \multirow[t]{2}{*}{ : } \\
\hline & \multicolumn{2}{|c|}{$\begin{array}{l}\text { How often does your help drive farm vehicles on public } \\
\text { roads? Would you say ...? [READ RESPONSES] }\end{array}$} & $\begin{array}{l}\text { Seldom } \\
\text { Sometimes } \\
\text { Most of the time, or the time }\end{array}$ & \\
\hline & Kural Koa as durve & & & \\
\hline
\end{tabular}




\begin{tabular}{|c|c|c|c|c|c|c|c|c|c|}
\hline 10. & \multicolumn{2}{|c|}{$\begin{array}{l}\text { Why do you or your help drive your farm } \\
\text { vehicles on public roads? } \\
\text { [CIRCLE ALL THAT APPLY] }\end{array}$} & \multicolumn{6}{|c|}{ 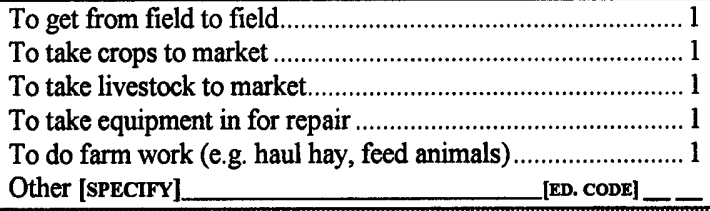 } & (4.80 \\
\hline 11. & \multicolumn{2}{|c|}{$\begin{array}{l}\text { Thinking about the public roads around your } \\
\text { farm that you use to transport farm vehicles, } \\
\text { what are the roads used for besides farming? } \\
\text { [CIRCLE ALL THAT APPLY] }\end{array}$} & \multicolumn{6}{|c|}{ 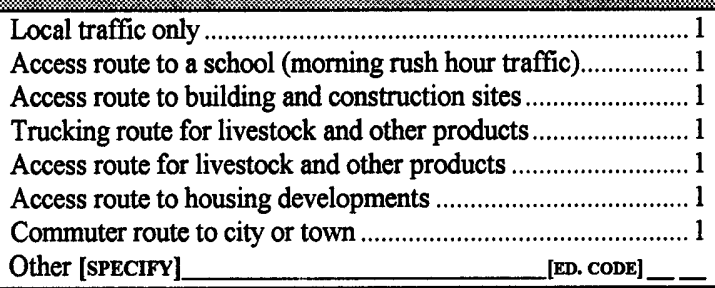 } & 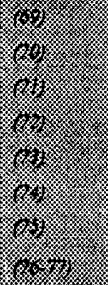 \\
\hline & & & & & & & & $\begin{array}{r}\text { Dup ID } \\
\text { Card 2 } \\
\end{array}$ & , \\
\hline 12. & \multicolumn{2}{|c|}{$\begin{array}{l}\text { Thinking about what it is like to drive on the } \\
\text { public roads near your farm, would you say } \\
\text { your farm is located in an area with ...? } \\
\text { [READ RESPONSES] [CIRCLE ONE } \\
\text { RESPONSE] }\end{array}$} & \multicolumn{6}{|c|}{ 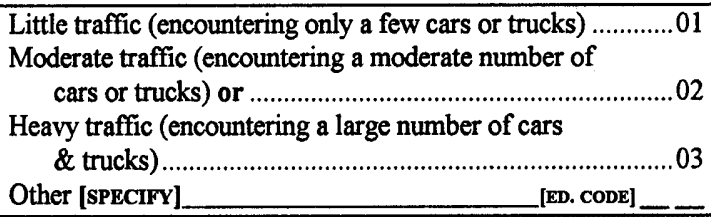 } & 8 \\
\hline 13. & \multirow{3}{*}{\multicolumn{8}{|c|}{$\begin{array}{l}\text { A. Would you tell me what types of farm vehicles or pieces of farm equipment you, or individuals who help } \\
\text { you, either drive or transport on public roads? [CIRCLE ALL THAT APPLY] [PROMPT BY VEHICLE TYPE } \\
\text { IF NECESSARY] } \\
\text { B. In what year was your oldest [vehicle/equipment type] manufactured? In what year was your newest } \\
\text { [vehicle/equipment type] manufactured? } \\
\text { C. How do you transport the [vehicle/equipment] on public roads? Is it-driven, loaded, towed, or transported } \\
\text { some other way? }\end{array}$}} & \\
\hline & & & & & & & & & \\
\hline & & & & & & & & & \\
\hline & $\begin{array}{l}\text { Types of farm vehicle or piece of } \\
\text { equipment (e.g.) tractor, combine, } \\
\text { harvester, specialty attachment, etc.) }\end{array}$ & $\begin{array}{l}\text { Vehicle or } \\
\text { Equipment } \\
\text { Mentioned }\end{array}$ & $\begin{array}{l}\text { Year of } \\
\text { Oldest Piece }\end{array}$ & $\begin{array}{c}\text { Year of } \\
\text { Newest Piece }\end{array}$ & Driven & $\begin{array}{l}\text { Loade } \\
d\end{array}$ & Towed & $\begin{array}{l}\text { Other } \\
\text { [SPECIFY] }\end{array}$ & \\
\hline & 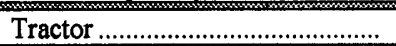 & $\ldots \ldots .1$ & ---- & --- & 1 & 1 & 1 & & 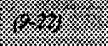 \\
\hline & 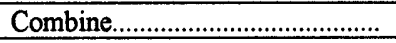 & $\ldots \ldots .1$ & --- & $=--$ & 1 & 1 & 1 & & 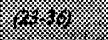 \\
\hline & Harvester........................................... & $\ldots \ldots .1$ & $-\ldots-$ & ---- & 1 & 1 & 1 & & 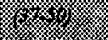 \\
\hline & Specialty attachment....................... & $\ldots \ldots . .1$ & $-\ldots$ & $-1-1$ & 1 & 1 & 1 & & 42 \\
\hline & Pickup truck ...................................... & $\ldots \ldots . .1$ & ---1 & ---- & 1 & 1 & 1 & & 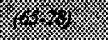 \\
\hline & & & & & & & & $\begin{array}{l}\text { Dup ID } \\
\text { Card 3 }\end{array}$ & $\sqrt{61}$ \\
\hline & Dump truck (2 ton).......................... & $\ldots \ldots . .1$ & --- & $--\cdots$ & 1 & 1 & 1 & & 18 \\
\hline & 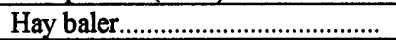 & $\ldots \ldots . .1$ & --- & $-\ldots-$ & 1 & 1 & 1 & & (2) \\
\hline & Other [SPECIFY] & $\ldots \ldots . .1$ & ---- & --- & 1 & 1 & 1 & & 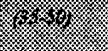 \\
\hline & Other [SPECIFY] & $\ldots \ldots . .1$ & ---- & $-\cdots-$ & 1 & 1 & 1 & & 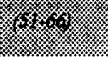 \\
\hline
\end{tabular}




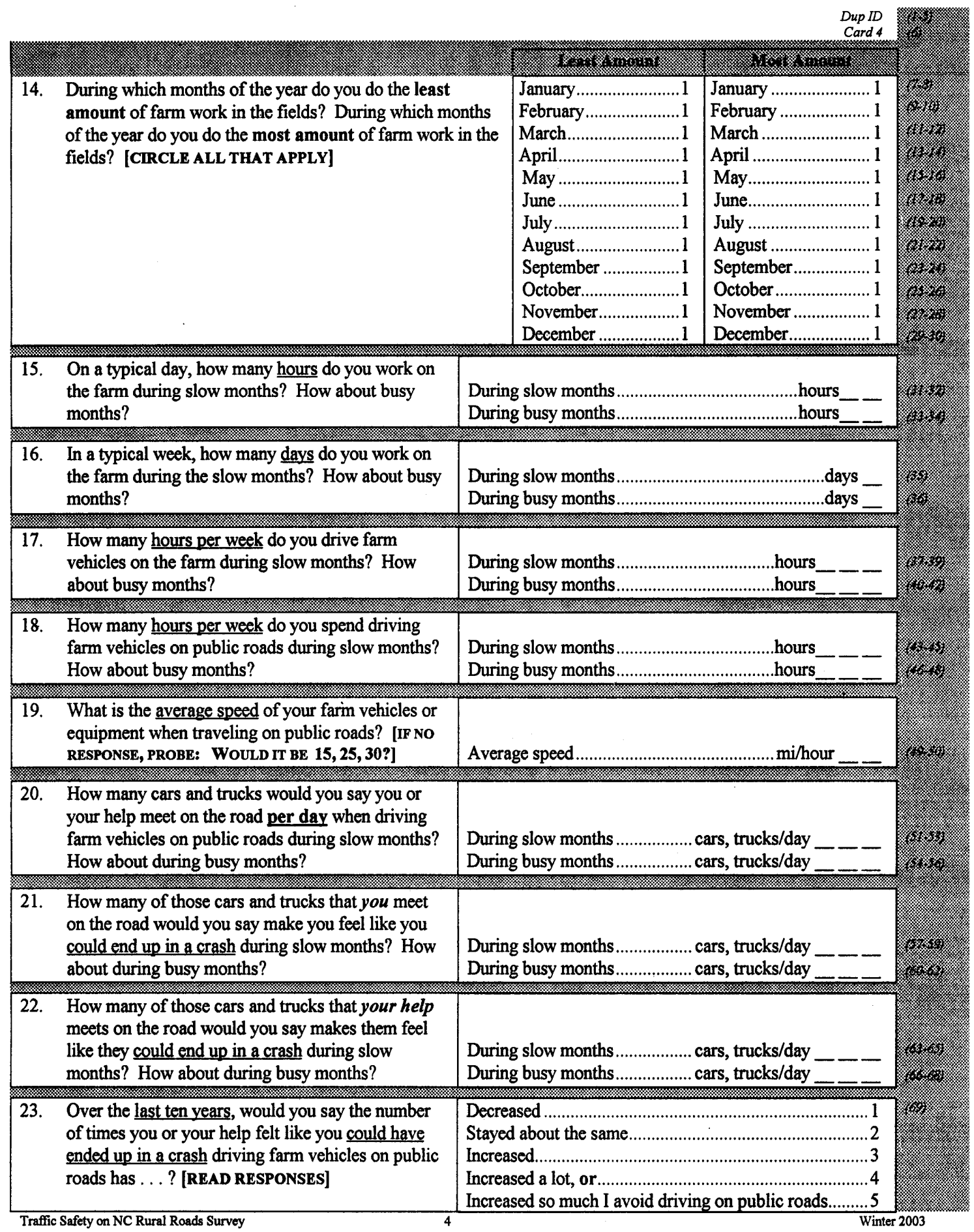




\begin{tabular}{|c|c|c|}
\hline & $\begin{array}{l}\text { How many times during } 2002 \text { did you feel like you } \\
\text { could have ended up in a crash when driving farm } \\
\text { vehicles on public roads? }\end{array}$ & Number of times..... \\
\hline \multirow[t]{2}{*}{25.} & $\begin{array}{l}\text { How many times during } 2002 \text { did your help feel } \\
\text { like they could have ended up in a crash when } \\
\text { driving farm vehicles on public roads? }\end{array}$ & Number of times.... \\
\hline & & $\begin{array}{l}\text { Dup ID } \\
\text { Card S } \\
\end{array}$ \\
\hline 26. & $\begin{array}{l}\text { Thinking about driving or transporting farm } \\
\text { vehicles or equipment on public roads, what kinds } \\
\text { of road conditions and driving behaviors contribute } \\
\text { to farm vehicle public road crashes? [DO NOT } \\
\text { READ LIST] [CIRCLE ALL THAT APPLY] }\end{array}$ & 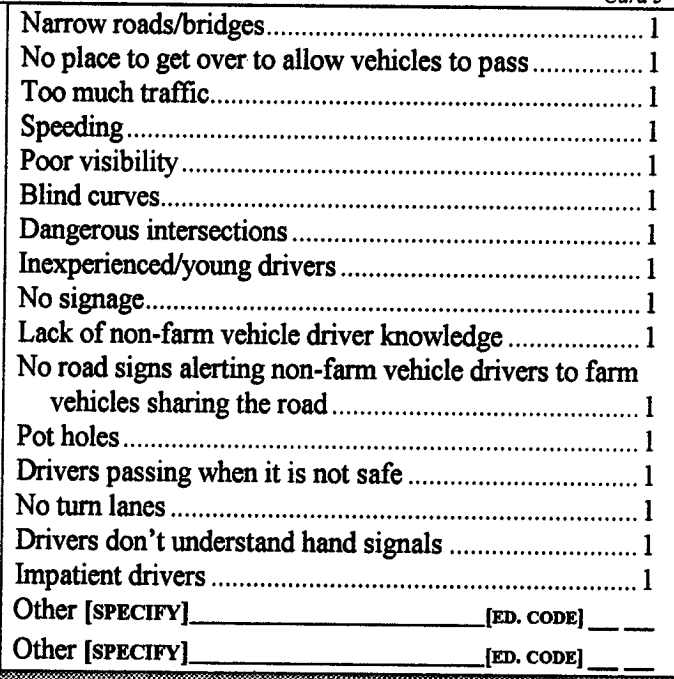 \\
\hline & $\begin{array}{l}\text { Thinking about driving farm vehicles on public } \\
\text { roads, what kind of things do or have you or your } \\
\text { help ever done to avoid being involved in a farm } \\
\text { vehicle public road crash? [DO NOT READ LIST] } \\
\text { [CIRCLE ALL THAT APPLY] }\end{array}$ & 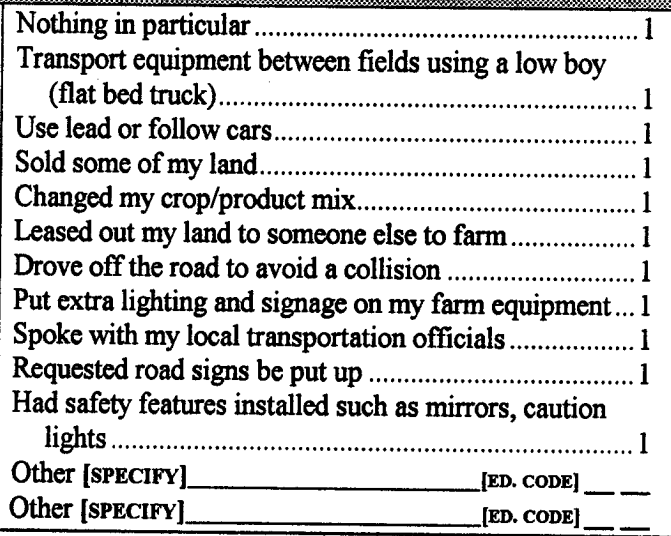 \\
\hline
\end{tabular}




\begin{tabular}{|c|c|c|c|c|c|}
\hline \multicolumn{5}{|c|}{$\begin{array}{l}\text { I'm going to read you a few statements. For each one, I'd like you to tell me if you "Strongly agree, agree, disagree, } \\
\text { or strongly disagree with it. Do you strongly agree, agree, disagree, or strongly disagree with the following statement } \\
\text {...? [READ ITEM] [CIRCLE ONE ANSWER ONLY] }\end{array}$} & \\
\hline 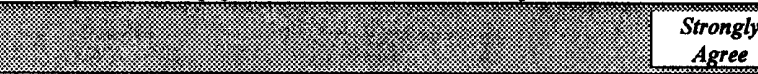 & Agree & Disagree & $\begin{array}{l}\text { Strongly } \\
\text { Disagree }\end{array}$ & $\begin{array}{l}\text { No Opinion } \\
\text { Don't Know }\end{array}$ & \\
\hline $\begin{array}{l}\text { 28. Driving farm vehicles on public roads is } \\
\text { dangerous. }\end{array}$ & $\ldots . . .3$ & $\ldots . . .2$ & $\ldots \ldots . .1$ & $\ldots \ldots . . .8$ & 18. \\
\hline 29. I feel safe driving farm vehicles on public roads...............4 & $\ldots . .3$ & $\ldots . .2$ & $\ldots \ldots .1$ & $\ldots \ldots . . .8$ & . \\
\hline $\begin{array}{l}\text { It is important to feel safe driving farm vehicles on } \\
\text { public roads. }\end{array}$ & $\ldots . .3$ & 2 & $\ldots \ldots . .1$ & $\ldots \ldots . . .8$ & 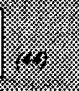 \\
\hline 31. Agriculture is a dangerous occupation. & $\ldots . .3$ & $\ldots \ldots . .2$ & $\ldots . .1$ & $\ldots . . . .8$ & (3). \\
\hline 32. I will be farming in five years. & $\ldots . .3$ & $\ldots \ldots . .2$ & $\ldots . .1$ & $\ldots \ldots . . .8$ & (1). \\
\hline $\begin{array}{l}\text { 33. Since you began working in agriculture, either as an owner } \\
\text { or paid employee, including working on a family farm, how } \\
\text { many crashes have you or your help had with your farm } \\
\text { vehicles on public roads? }\end{array}$ & $\begin{array}{l}\text { Number of } \mathrm{c} \\
\text { [IF RESPONSE }\end{array}$ & ashes & TO Q47] & ……- & 4.83. \\
\hline $\begin{array}{l}34 \text { How many of those crashes you mentioned happened within } \\
\text { the last } 10 \text { years (since 1992)? }\end{array}$ & Number of $\mathrm{c}$ & ashes. & & $\cdots \cdot=$ & $(4)$ \\
\hline $\begin{array}{l}\text { 35. In what month and year did the most recent farm vehicle } \\
\text { crash occur? [CIRCLE ONE RESPONSE FOR MONTH AND } \\
\text { ONE RESPONSE FOR YEAR] }\end{array}$ & 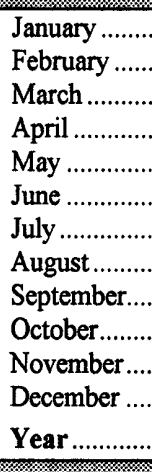 & (1) & (1) & 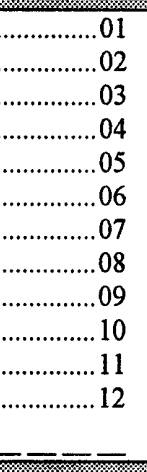 & : \\
\hline 36. Who was driving? [CIRCLE ONE RESPONSE] & $\begin{array}{l}\text { Myself........... } \\
\text { Spouse ........ } \\
\text { Son(s)/son(s) } \\
\text { Daughter(s)d } \\
\text { Father/father } \\
\text { Brother(s)/br } \\
\text { Sister(s)/siste } \\
\text { Cousins, uncl } \\
\text { Friends ........ } \\
\text { Non-family h } \\
\text { Other [sPECr }\end{array}$ & 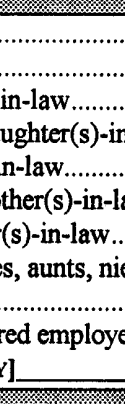 & 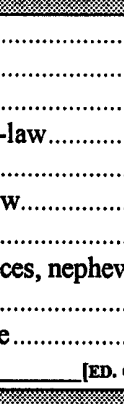 & 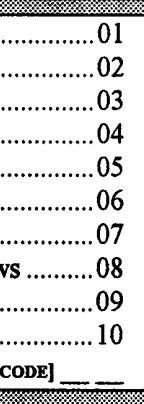 & : \\
\hline $\begin{array}{l}\text { 37. In what year did you or the person driving start working in } \\
\text { agriculture either as a family member or paid employee? }\end{array}$ & Year started. & & ..... & & (:3: \\
\hline
\end{tabular}




\begin{tabular}{|c|c|c|c|c|}
\hline \multirow[t]{2}{*}{38.} & \multicolumn{2}{|c|}{$\begin{array}{l}\text { How old were you/the person driving at the time of the } \\
\text { crash? }\end{array}$} & Age & \\
\hline & & & $\begin{array}{l}\text { Dup ID } \\
\text { Card } 6 \\
\end{array}$ & r \\
\hline 39. & \multicolumn{3}{|c|}{$\begin{array}{l}\text { Which of your farm vehicles or equipment were involved? In what year was the vehicle or equipment } \\
\text { manufactured? [CIRCLE ALL THAT APPLY] }\end{array}$} & \\
\hline & \multicolumn{2}{|c|}{ S } & Year Manufactured & \\
\hline & \multicolumn{3}{|c|}{ 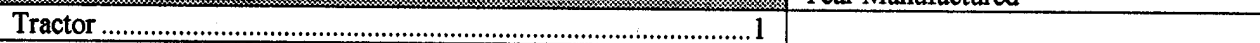 } & 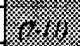 \\
\hline & \multicolumn{3}{|c|}{ Combine } & (6.8. \\
\hline & \multicolumn{2}{|c|}{ Harvester } & & \\
\hline & \multicolumn{3}{|c|}{ Attachments ................................................................................... } & 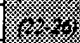 \\
\hline & \multicolumn{3}{|c|}{ 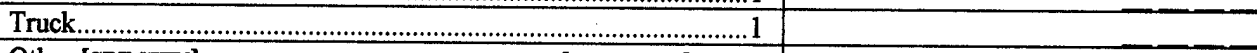 } & 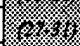 \\
\hline & \multicolumn{3}{|c|}{$\begin{array}{l}\text { Other [SPECIFY] } \\
\text { [ED. CODE] }\end{array}$} & 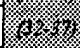 \\
\hline 40. & $\begin{array}{l}\text { What non-farm vehicles were involved, } \\
\text { for example: car, minivan, SUV? } \\
\text { [CIRCLE ALL THAT APPLY] }\end{array}$ & \multicolumn{2}{|c|}{$\begin{array}{l}\text { No non-farm vehicles were involved in the farm vehicle crash } \\
\text { Passenger car } \\
\text { Minivan } \\
\text { SUV } \\
\text { Truck } \\
\text { Tractor trailer } \\
\text { Other [SPECIFY] }\end{array}$} & 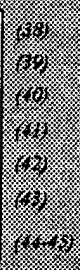 \\
\hline & $\begin{array}{l}\text { Thinking about driving or transporting } \\
\text { farm vehicles or equipment on public } \\
\text { roads, what kinds of road conditions and } \\
\text { driving behaviors contributed to the farm } \\
\text { vehicle public road crash? [DO NOT REA } \\
\text { LIST] [CIRCLE ALL THAT APPLY] }\end{array}$ & \multicolumn{2}{|c|}{ 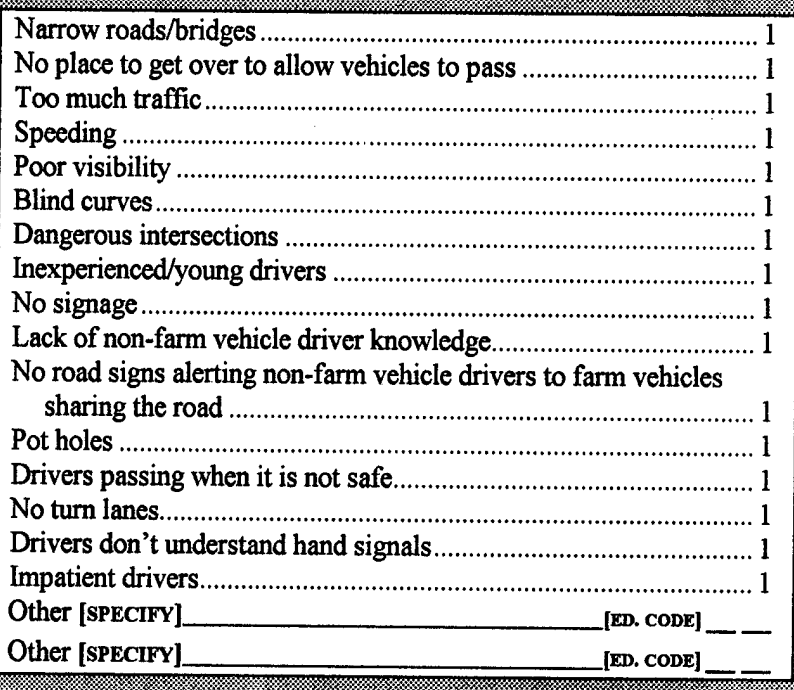 } & 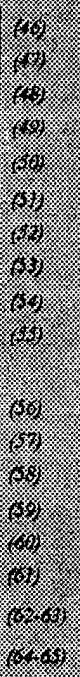 \\
\hline 42. & \multicolumn{2}{|l|}{ Was a police report filed? } & 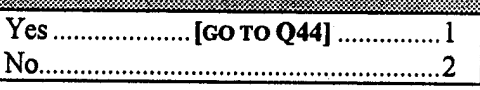 & (1) \\
\hline & 43. [IF NO:] Why not? & \multicolumn{2}{|c|}{ 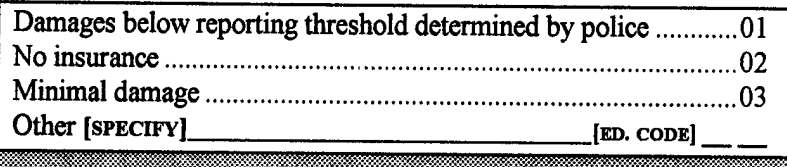 } & 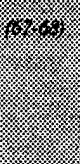 \\
\hline 44. & \multicolumn{2}{|l|}{ Was anyone injured in the crash? } & 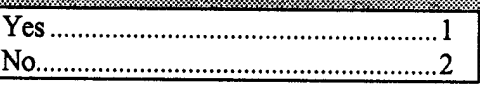 & \\
\hline
\end{tabular}




\begin{tabular}{|c|c|c|c|c|}
\hline \multicolumn{3}{|c|}{ 45. Did anyone die in the crash? } & Yes & \\
\hline \multirow[t]{2}{*}{46.} & \multicolumn{2}{|c|}{$\begin{array}{l}\text { Thinking about public road conditions now and at the time } \\
\text { of the crash, would you say public road conditions now are } \\
\text { worse, the same or better than at the time of the crash? }\end{array}$} & Worse & \\
\hline & & & $\begin{array}{rr}\text { Dup } D \\
\text { Card } 7 \\
\end{array}$ & $\sqrt[8]{8.8}$ \\
\hline 47. & $\begin{array}{l}\text { If you could change anything that would } \\
\text { make public roads safer for farmers } \\
\text { driving farm vehicles on public roads, } \\
\text { what would you suggest? [DO NOT } \\
\text { READ LIST] [CIRCLE ALL THAT } \\
\text { APPLY] }\end{array}$ & \multicolumn{2}{|c|}{ 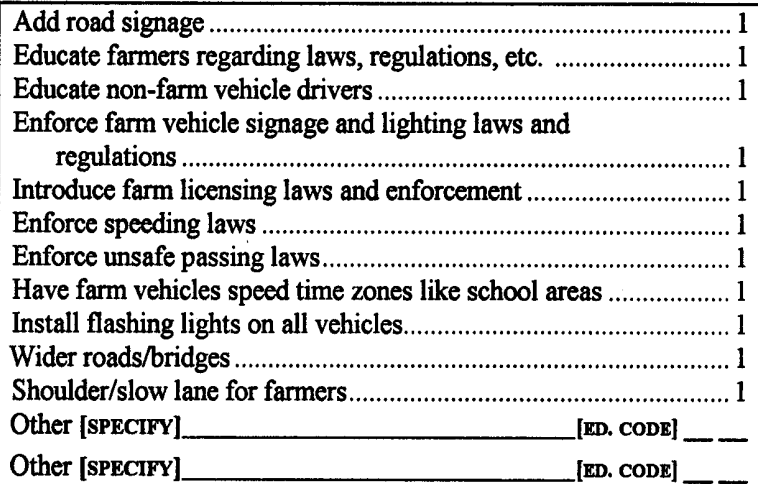 } & (3) \\
\hline
\end{tabular}

We are almost finished. I have just a few questions I would like to ask for demographic purposes only. [REMIND OF ANONYMITY AND CONFIDENTIALITY]

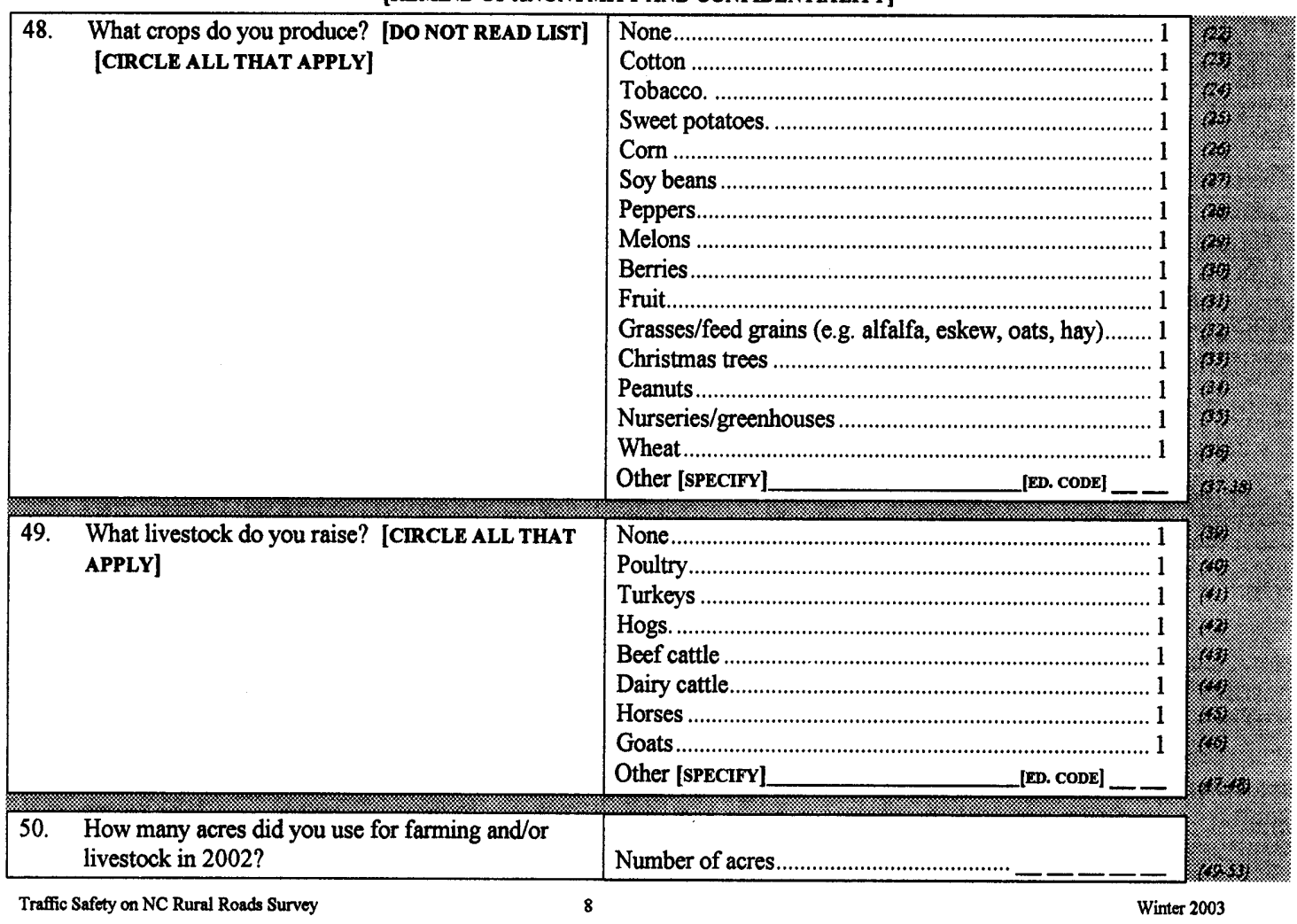




\begin{tabular}{|c|c|c|}
\hline 51. In what North Carolina county (ies) do you farm? & 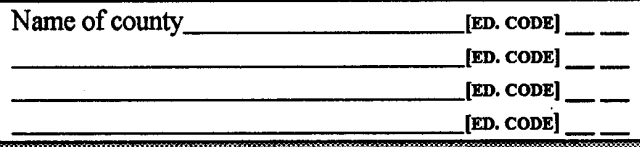 & 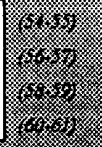 \\
\hline $\begin{array}{l}\text { 52. While working in agriculture, how many times have } \\
\text { you been injured badly enough on the job that you } \\
\text { had to miss a day of work or receive medical } \\
\text { treatment? }\end{array}$ & Number of times & \\
\hline $\begin{array}{l}\text { 53. In what year did you start working in agriculture } \\
\text { either as a family member or paid employee? }\end{array}$ & 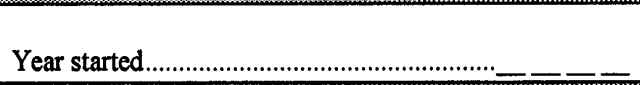 & 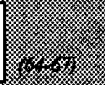 \\
\hline $\begin{array}{l}\text { 54. In what year were you born? } \\
\text { [LET RESPONDENT VOLUNTEER] }\end{array}$ & 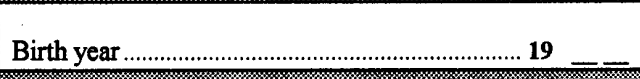 & $\sqrt[3]{2}$ \\
\hline $\begin{array}{l}\text { 55. To what racial group do you belong? } \\
\text { [LET RESPONDENT VOLUNTEER] }\end{array}$ & $\begin{array}{l}\text { White (Caucasian) } \\
\text { Black (African-American) } \\
\text { American Indian or Alaskan Native } \\
\text { Asian-American } \\
\text { Native Hawaiian or Pacific Islander } \\
\text { Other [SPECIFY] }\end{array}$ & 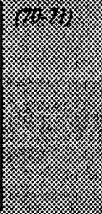 \\
\hline $\begin{array}{l}\text { 56. What is the highest level of education you have } \\
\text { completed? [CIRCLE ONE RESPONSE ONLY] }\end{array}$ & $\begin{array}{l}\text { Elementary school } \\
\text { Some high school } \\
\text { High school graduate } \\
\text { Technical/Trade school } \\
\text { Some college } \\
\text { College graduate } \\
\text { Post graduate work }\end{array}$ & \\
\hline $\begin{array}{l}\text { 57. Over the last five years (e.g. since 1997) what } \\
\text { would you say were your gross farm sales before } \\
\text { taxes for a typical year? Was it ... ? [READ LIST] } \\
\text { [CIRCLE ONE RESPONSE ONLY] }\end{array}$ & $\begin{array}{l}\$ 0-\$ 24,999 \\
\$ 25,000-\$ 49,999 \\
\$ 50,000-\$ 74,999 \\
\$ 75,000-\$ 99,999 \\
\$ 100,000-\$ 124,999 \\
\$ 125,000-\$ 149,999 \\
\$ 150,000-\$ 174,999 \\
\$ 175,000-\$ 199,999\end{array}$ & 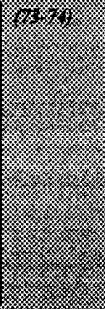 \\
\hline $\begin{array}{l}\text { 58. CODE RESPONDENT'S GENDER } \\
\text { [ASK IF UNSURE] }\end{array}$ & Male & (83: \\
\hline & $\begin{array}{r}-120 \\
-\end{array}$ & (18: \\
\hline \multicolumn{2}{|c|}{$\begin{array}{l}\text { Is there anything else you would like to mention regarding farm vehicle public road safety that you feel would be } \\
\text { important for us to understand in addressing the safety concerns of North Carolina farmers? }\end{array}$} & \\
\hline
\end{tabular}

Thank you for taking the time to participate in this study. Your input has been very helpful. Traffic Safety on NC Rural Roads Survey 


\title{
Traffic Safety ON NORTH CaRolina RURAL ROADS 2003
}

\section{Data Set Code Guide}

\author{
Wanda Simmons \\ Research Associate \\ CENTER FOR URBAN AFFAIRS \& COMMUNITY SERVICES \\ NORTH CAROLINA STATE UNIVERSITY
}




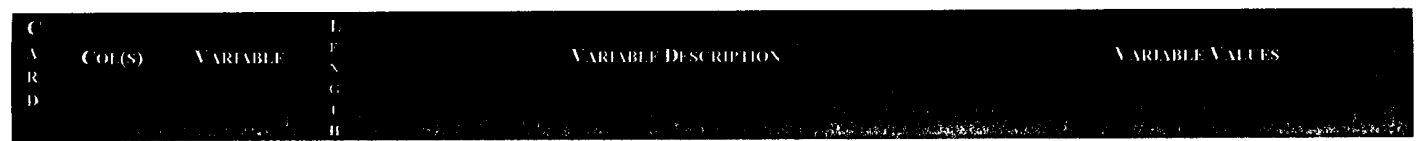

\begin{tabular}{|c|c|c|c|c|c|}
\hline 1 & $1-5$ & ID1 & 5 & Identification Number - Card One & Values $=00010-14762$ \\
\hline 1 & 6 & CARD1 & 1 & Card Number - Card One & CARD 1 always $=1$ \\
\hline 1 & 7 & $\mathrm{QB}$ & 1 & $\begin{array}{l}\text { Question B. Do you, your family members, or your } \\
\text { employees drive or transport farm tractors or other farm } \\
\text { equipment on public roads? }\end{array}$ & $\begin{array}{l}1=\text { Yes } \\
2=\text { No }\end{array}$ \\
\hline 1 & 8 & $\mathrm{QC1}$ & 1 & $\begin{array}{l}\text { Question C1. Why do you not drive your farm tractors } \\
\text { or equipment on public roads? } \\
\text { My land is all together so I don't have to use public } \\
\text { roads }\end{array}$ & $1=$ Mentioned \\
\hline 1 & 9 & QC2 & 1 & $\begin{array}{l}\text { Question C2. Why do you not drive your farm tractors } \\
\text { or equipment on public roads? } \\
\text { Someone else besides my employees or me does the } \\
\text { driving }\end{array}$ & $1=$ Mentioned \\
\hline 1 & 10 & $\overline{Q C 3}$ & 1 & $\begin{array}{l}\text { Question C3. Why do you not drive your farm tractors } \\
\text { or equipment on public roads? } \\
\text { I am a contract producer }\end{array}$ & $1=$ Mentioned \\
\hline 1 & 11 & QC4 & 1 & $\begin{array}{l}\text { Question C4. Why do you not drive your farm tractors } \\
\text { or equipment on public roads? } \\
\text { I am not actively involved in farming }\end{array}$ & $1=$ Mentioned \\
\hline 1 & 12 & QC5 & 1 & $\begin{array}{l}\text { Question C5. Why do you not drive your farm tractors } \\
\text { or equipment on public roads? } \\
\text { I am retired }\end{array}$ & $1=$ Mentioned \\
\hline 1 & $13-14$ & QC6 & 2 & $\begin{array}{l}\text { Question C6. Why do you not drive your farm tractors } \\
\text { or equipment on public roads? } \\
\text { Other reason }\end{array}$ & No values \\
\hline 1 & 15 & $\overline{Q D}$ & 1 & $\begin{array}{l}\text { Question D. Have you or anyone helping you with farm } \\
\text { work been involved in a farm vehicle crash on a public } \\
\text { road in the last } 10 \text { years (since 1992)? }\end{array}$ & $\begin{array}{l}1=\text { Yes } \\
2=\text { No }\end{array}$ \\
\hline 1 & $16-17$ & $\overline{Q 1}$ & 2 & $\begin{array}{l}\text { Question } 1 . \text { What is your primary role in the farming } \\
\text { operation? }\end{array}$ & $\begin{array}{l}1=\text { Farm operator/owner } \\
2=\text { Farm spouse } \\
3=\text { Family farm member } \\
4=\text { Family farm relative } \\
5=\text { Full-time }, \text { non-family hired worker } \\
6 \text { = Part-time, non-family hired worker } \\
7=\text { Hired, non-family manager } / \\
\quad \text { supervisor }\end{array}$ \\
\hline 1 & $18-19$ & Q2 & 2 & $\begin{array}{l}\text { Question 2. How many farm operations do you own or } \\
\text { manage? }\end{array}$ & Values $=1-30$ Farm operations \\
\hline 1 & $20-23$ & $\overline{\mathrm{Q} 3}$ & 4 & $\begin{array}{l}\text { Question 3. How many individuals help you with farm } \\
\text { work throughout the growing season? }\end{array}$ & $\begin{array}{l}\text { Values }=1-100 \text { Individuals } \\
0=\text { No individuals help with farm work }\end{array}$ \\
\hline 1 & 24 & Q4A1 & 1 & $\begin{array}{l}\text { Question 4A1. Who drives your farm vehicles on the } \\
\text { farm? } \\
\text { Self }\end{array}$ & $1=$ Mentioned \\
\hline 1 & 25 & Q4A2 & 1 & $\begin{array}{l}\text { Question 4A2. Who drives your farm vehicles on public } \\
\text { roads? } \\
\text { Self }\end{array}$ & $1=$ Mentioned \\
\hline
\end{tabular}




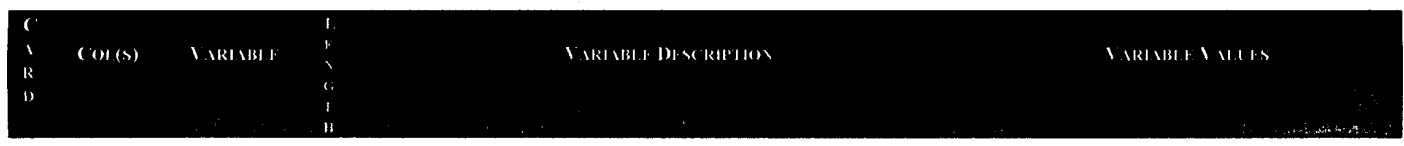

\begin{tabular}{|c|c|c|c|c|c|}
\hline 1 & 26 & Q4B1 & 1 & $\begin{array}{l}\text { Question 4B1. Who drives your farm vehicles on the } \\
\text { farm? } \\
\text { Spouse }\end{array}$ & $1=$ Mentioned \\
\hline 1 & 27 & Q4B2 & 1 & $\begin{array}{l}\text { Question 4B2. Who drives your farm vehicles on public } \\
\text { roads? } \\
\text { Spouse }\end{array}$ & $1=$ Mentioned \\
\hline 1 & 28 & $\mathrm{Q} 4 \mathrm{Cl}$ & 1 & $\begin{array}{l}\text { Question } 4 \mathrm{C} 1 . \text { Who drives your farm vehicles on the } \\
\text { farm? } \\
\text { Son(s)/son(s)-in-law }\end{array}$ & $1=$ Mentioned \\
\hline 1 & 29 & $\mathrm{Q} 4 \mathrm{C} 2$ & 1 & $\begin{array}{l}\text { Question } 4 \mathrm{C} 2 \text {. Who drives your farm vehicles on public } \\
\text { roads? } \\
\text { Son(s)/son(s)-in-law }\end{array}$ & $1=$ Mentioned \\
\hline 1 & 30 & Q4D1 & 1 & $\begin{array}{l}\text { Question 4D1. Who drives your farm vehicles on the } \\
\text { farm? } \\
\text { Daughter(s)/daughter(s)-in-law }\end{array}$ & $1=$ Mentioned \\
\hline 1 & 31 & Q4D2 & 1 & $\begin{array}{l}\text { Question 4D2. Who drives your farm vehicles on public } \\
\text { roads? } \\
\text { Daughter(s)/daughter(s)-in-law }\end{array}$ & $1=$ Mentioned \\
\hline 1 & 32 & Q4E1 & 1 & $\begin{array}{l}\text { Question 4E1. Who drives your farm vehicles on the } \\
\text { farm? } \\
\text { Father/father-in-law }\end{array}$ & $1=$ Mentioned \\
\hline 1 & 33 & Q4E2 & 1 & $\begin{array}{l}\text { Question 4E2. Who drives your farm vehicles on public } \\
\text { roads? } \\
\text { Father/father-in-law }\end{array}$ & $1=$ Mentioned \\
\hline 1 & 34 & Q4F1 & 1 & $\begin{array}{l}\text { Question 4F1. Who drives your farm vehicles on the } \\
\text { farm? } \\
\text { Brother(s)/brother(s)-in-law }\end{array}$ & $1=$ Mentioned \\
\hline 1 & 35 & Q4F2 & 1 & $\begin{array}{l}\text { Question 4F2. Who drives your farm vehicles on public } \\
\text { roads? } \\
\text { Brother(s)/brother(s)-in-law }\end{array}$ & $1=$ Mentioned \\
\hline 1 & 36 & Q4G1 & 1 & $\begin{array}{l}\text { Question 4G1. Who drives your farm vehicles on the } \\
\text { farm? } \\
\text { Sister(s)/Sister(s)-in-law }\end{array}$ & $1=$ Mentioned \\
\hline 1 & 37 & Q4G2 & 1 & $\begin{array}{l}\text { Question 4G2. Who drives your farm vehicles on public } \\
\text { roads? } \\
\text { Sister(s)/ Sister(s)-in-law }\end{array}$ & $1=$ Mentioned \\
\hline 1 & 38 & Q4H1 & 1 & $\begin{array}{l}\text { Question } 4 \mathrm{H} 1 \text {. Who drives your farm vehicles on the } \\
\text { farm? } \\
\text { Cousins, uncles, aunts, nieces, nephews, etc. }\end{array}$ & $1=$ Mentioned \\
\hline 1 & 39 & Q4H2 & 1 & $\begin{array}{l}\text { Question } 4 \mathrm{H} 2 \text {. Who drives your farm vehicles on public } \\
\text { roads? } \\
\text { Cousins, uncles, aunts, nieces, nephews, etc. }\end{array}$ & $1=$ Mentioned \\
\hline
\end{tabular}




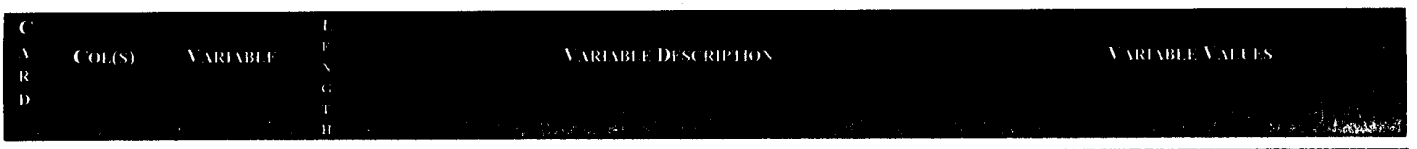

\begin{tabular}{|c|c|c|c|c|c|}
\hline 1 & 40 & Q4I1 & 1 & $\begin{array}{l}\text { Question 4I1. Who drives your farm vehicles on the } \\
\text { farm? } \\
\text { Friends }\end{array}$ & $1=$ Mentioned \\
\hline 1 & 41 & Q412 & 1 & $\begin{array}{l}\text { Question 4I2. Who drives your farm vehicles on public } \\
\text { roads? } \\
\text { Friends }\end{array}$ & $1=$ Mentioned \\
\hline 1 & 42 & Q4J1 & 1 & $\begin{array}{l}\text { Question 4JI. Who drives your farm vehicles on the } \\
\text { farm? } \\
\text { Non-family hired emplovees }\end{array}$ & $1=$ Mentioned \\
\hline 1 & 43 & Q4J2 & 1 & $\begin{array}{l}\text { Question } 4 \mathrm{~J} 2 . \text { Who drives your farm vehicles on public } \\
\text { roads? } \\
\text { Non-family hired employees }\end{array}$ & $1=$ Mentioned \\
\hline 1 & $\overline{44-45}$ & Q4K1 & 2 & $\begin{array}{l}\text { Question } 4 \mathrm{~K} 1 \text {. Who drives your farm vehicles on the } \\
\text { farm? } \\
\text { First other person }\end{array}$ & $\begin{array}{l}01=\text { Mother } \\
02=\text { Grandson }\end{array}$ \\
\hline 1 & $46-47$ & Q4K2 & 2 & $\begin{array}{l}\text { Question } 4 \mathrm{~K} 2 \text {. Who drives your farm vehicles on public } \\
\text { roads? } \\
\text { Second other nerson }\end{array}$ & $\begin{array}{l}01=\text { Mother } \\
02=\text { Grandson }\end{array}$ \\
\hline 1 & $48-51$ & Q5 & 4 & $\begin{array}{l}\text { Question } 5 \text {. How many of those individuals helping you } \\
\text { drive farm vehicles speak another language at work } \\
\text { besides English? }\end{array}$ & $\begin{array}{l}\text { Values }=1-70 \text { Individuals } \\
0=\text { No individuals speak another } \\
\text { language }\end{array}$ \\
\hline 1 & $52-53$ & Q6A & 2 & $\begin{array}{l}\text { Question 6A. What is the age of the voungest person } \\
\text { driving farm vehicles on the farm? }\end{array}$ & Values $=10-93$ Years of age \\
\hline 1 & $54-55$ & Q6B & 2 & $\begin{array}{l}\text { Question } 6 \mathrm{~B} \text {. What is the age of the youngest person } \\
\text { driving farm vehicles on public roads? }\end{array}$ & Values $=12-93$ Years of age \\
\hline$\overline{1}$ & $56-57$ & Q7A & 2 & $\begin{array}{l}\text { Question } 7 \mathrm{~A} \text {. What is the age of the oldest person } \\
\text { driving farm vehicles on the farm? }\end{array}$ & Values $=21-93$ Years of age \\
\hline 1 & $58-59$ & Q7B & 2 & $\begin{array}{l}\text { Question 7B. What is the age of the oldest person } \\
\text { driving farm vehicles on public roads? }\end{array}$ & Values $=22-93$ Years of age \\
\hline 1 & 60 & Q8 & 1 & $\begin{array}{l}\text { Question } 8 . \text { How often do you drive farm vehicles on } \\
\text { public roads? }\end{array}$ & $\begin{array}{l}1=\text { Seldom } \\
2=\text { Sometimes } \\
3=\text { Most of the time } \\
4=\text { All of the time }\end{array}$ \\
\hline 1 & 61 & Q9 & 1 & $\begin{array}{l}\text { Question 9. How often does your help drive farm } \\
\text { vehicles on public roads? }\end{array}$ & $\begin{array}{l}1=\text { Seldom } \\
2=\text { Sometimes } \\
3=\text { Most of the time } \\
4=\text { All of the time } \\
5=\text { N/A - no help/help does not drive }\end{array}$ \\
\hline 1 & 62 & Q10A & 1 & $\begin{array}{l}\text { Question 10A. Why do you or your help drive your } \\
\text { farm vehicles on public roads? } \\
\text { To get from field to field }\end{array}$ & $1=$ Mentioned \\
\hline 1 & 63 & Q10B & 1 & $\begin{array}{l}\text { Question 10B. Why do you or your help drive your } \\
\text { farm vehicles on public roads? } \\
\text { To take crops to market }\end{array}$ & $1=$ Mentioned \\
\hline
\end{tabular}




\begin{tabular}{|c|c|c|c|c|c|}
\hline $\begin{array}{l}6 \\
1 \\
18 \\
13\end{array}$ & $\operatorname{lol}(s)$ & IIRIUB।.F & $\begin{array}{c}1 \\
\vdots \\
i \\
i\end{array}$ & 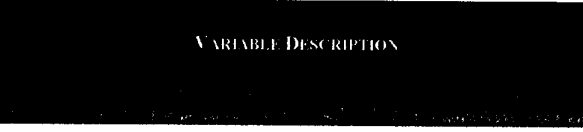 & is \\
\hline 1 & 64 & Q10C & 1 & $\begin{array}{l}\text { Question 10C. Why do you or your help drive your } \\
\text { farm vehicles on public roads? } \\
\text { To take livestock to market }\end{array}$ & $1=$ Mentioned \\
\hline 1 & 65 & QI0D & 1 & $\begin{array}{l}\text { Question 10D. Why do you or your help drive your } \\
\text { farm vehicles on public roads? } \\
\text { To take equipment in for repair }\end{array}$ & $1=$ Mentioned \\
\hline 1 & 66 & Q10E & 1 & $\begin{array}{l}\text { Question 10E. Why do you or your help drive your farm } \\
\text { vehicles on public roads? } \\
\text { To do farm work }\end{array}$ & $1=$ Mentioned \\
\hline 1 & $67-68$ & Q10F & 2 & $\begin{array}{l}\text { Question } 10 \mathrm{~F} \text {. Why do you or your help drive your farm } \\
\text { vehicles on public roads? } \\
\text { Other }\end{array}$ & No values \\
\hline 1 & 69 & Q11A & 1 & $\begin{array}{l}\text { Question 11A. Thinking about the public roads around } \\
\text { your farm that you use to transport farm vehicles, what } \\
\text { are the roads used for besides farming? } \\
\text { Local traffic only }\end{array}$ & $1=$ Mentioned \\
\hline 1 & 70 & Q11B & 1 & $\begin{array}{l}\text { Question l1B. Thinking about the public roads around } \\
\text { your farm that you use to transport farm vehicles, what } \\
\text { are the roads used for besides farming? } \\
\text { Access route to a school (morning rush hour traffic) }\end{array}$ & $1=$ Mentioned \\
\hline 1 & 71 & Q11C & 1 & $\begin{array}{l}\text { Question 11C. Thinking about the public roads around } \\
\text { your farm that you use to transport farm vehicles, what } \\
\text { are the roads used for besides farming? } \\
\text { Access route to a building and construction sites }\end{array}$ & $1=$ Mentioned \\
\hline 1 & 72 & Q11D & 1 & $\begin{array}{l}\text { Question 11D. Thinking about the public roads around } \\
\text { your farm that you use to transport farm vehicles, what } \\
\text { are the roads used for besides farming? } \\
\text { Trucking route for livestock and other products }\end{array}$ & $1=$ Mentioned \\
\hline 1 & 73 & Q11E & 1 & $\begin{array}{l}\text { Question l1E. Thinking about the public roads around } \\
\text { your farm that you use to transport farm vehicles, what } \\
\text { are the roads used for besides farming? } \\
\text { Access route for livestock and other products }\end{array}$ & $1=$ Mentioned \\
\hline 1 & 74 & Q11F & 1 & $\begin{array}{l}\text { Question 11F. Thinking about the public roads around } \\
\text { your farm that you use to transport farm vehicles, what } \\
\text { are the roads used for besides farming? } \\
\text { Access route to housing developments }\end{array}$ & $1=$ Mentioned \\
\hline 1 & 75 & Q11G & 1 & $\begin{array}{l}\text { Question } 11 \mathrm{G} \text {. Thinking about the public roads around } \\
\text { your farm that you use to transport farm vehicles, what } \\
\text { are the roads used for besides farming? } \\
\text { Commuter route to city or town }\end{array}$ & $1=$ Mentioned \\
\hline 1 & $76-77$ & Q11H & 2 & $\begin{array}{l}\text { Question } 11 \mathrm{H} \text {. Thinking about the public roads around } \\
\text { your farm that you use to transport farm vehicles, what } \\
\text { are the roads used for besides farming? } \\
\text { Other }\end{array}$ & $01=$ Logging truck route \\
\hline
\end{tabular}




\begin{tabular}{|c|c|c|c|c|c|}
\hline $\begin{array}{l}c \\
1 \\
1 \\
1\end{array}$ & $\cos (s)$ & I IRI \|в। & $\begin{array}{l}1 \\
i \\
i \\
i \\
i 1\end{array}$ & 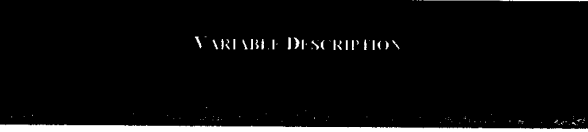 & 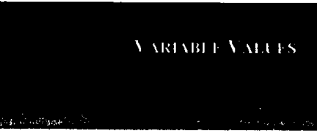 \\
\hline 2 & $1-5$ & ID2 & 5 & Identification Number - Card Two & Values $=00010-14762$ \\
\hline 2 & 6 & CARD2 & 1 & Card Number - Card Two & CARD2 always $=2$ \\
\hline 2 & $7-8$ & Q12 & 2 & $\begin{array}{l}\text { Question 12. Thinking about what it is like to drive on } \\
\text { the public roads near your farm, would you say your } \\
\text { farm is located in an area with little traffic, moderate } \\
\text { traffic or heavy traffic? }\end{array}$ & $\begin{array}{l}01=\text { Little traffic } \\
02=\text { Moderate traffic } \\
03=\text { Heavy traffic }\end{array}$ \\
\hline 2 & 9 & Q13aA & 1 & $\begin{array}{l}\text { Question 13aA. Would you tell me what types of farm } \\
\text { vehicles or pieces of farm equipment you, or individuals } \\
\text { who help you, either drive or transport on public roads? } \\
\text { Tractor }\end{array}$ & $1=$ Yes \\
\hline 2 & $10-13$ & Q13aB1 & 4 & $\begin{array}{l}\text { Question 13aB1. In what year was your oldest } \\
\text { [vehicle/equipment] manufactured? }\end{array}$ & $\begin{array}{c}\text { Values }=1930-2002 \text { Year } \\
\text { manufactured }\end{array}$ \\
\hline 2 & $14-17$ & Q13aB2 & 4 & $\begin{array}{l}\text { Question 13aB2. In what year was your newest } \\
\text { [vehicle/equipment] manufactured? }\end{array}$ & $\begin{array}{c}\text { Values }=1945-2003 \text { Year } \\
\text { manufactured }\end{array}$ \\
\hline 2 & 18 & $\mathrm{Q} 13 \mathrm{aCl}$ & 1 & $\begin{array}{l}\text { Question } 13 \mathrm{aCI} \text {. How do you transport the vehicle/ } \\
\text { equipment] on public roads? Is it ...? } \\
\text { Driven }\end{array}$ & $1=$ Yes \\
\hline 2 & 19 & $\mathrm{Q} 13 \mathrm{aC2}$ & 1 & $\begin{array}{l}\text { Question } 13 \mathrm{aC} 2 \text {. How do you transport the [vehicle/ } \\
\text { equipment] on public roads? Is it ...? } \\
\text { Loaded }\end{array}$ & $1=$ Yes \\
\hline 2 & 20 & Q13aC3 & 1 & $\begin{array}{l}\text { Question 13aC3. How do you transport the [vehicle/ } \\
\text { equipment] on public roads? Is it ...? } \\
\text { Towed }\end{array}$ & $1=$ Yes \\
\hline 2 & $21-22$ & $\mathrm{Q} 13 \mathrm{aC4}$ & 2 & $\begin{array}{l}\text { Question } 13 \mathrm{aC} 4 \text {. How do you transport the [vehicle/ } \\
\text { equipment] on public roads? Is it ...? } \\
\text { Transported some other way }\end{array}$ & No values \\
\hline 2 & 23 & Q13bA & 1 & $\begin{array}{l}\text { Question } 13 \mathrm{bA} \text {. Would you tell me what types of farm } \\
\text { vehicles or pieces of farm equipment you, or individuals } \\
\text { who help you, either drive or transport on public roads? } \\
\text { Combine }\end{array}$ & $1=$ Yes \\
\hline 2 & $24-27$ & Q13bB1 & 4 & $\begin{array}{l}\text { Question 13bB1. In what year was your oldest } \\
\text { [vehicle/equipment] manufactured? }\end{array}$ & $\begin{array}{c}\text { Values }=1955-2001 \text { Year } \\
\text { manufactured }\end{array}$ \\
\hline 2 & $28-31$ & $\mathrm{Q} 13 \mathrm{bB} 2$ & 4 & $\begin{array}{l}\text { Question } 13 \mathrm{bB} 2 . \text { In what year was your newest } \\
\text { [vehicle/equipment] manufactured? }\end{array}$ & $\begin{array}{c}\text { Values }=1955-2002 \text { Year } \\
\text { manufactured }\end{array}$ \\
\hline 2 & 32 & Q13bCl & 1 & $\begin{array}{l}\text { Question } 13 \mathrm{bCl} \text {. How do you transport the [vehicle/ } \\
\text { equipment] on public roads? Is it ...? } \\
\text { Driven }\end{array}$ & $1=$ Yes \\
\hline 2 & 33 & Q13bC2 & 1 & $\begin{array}{l}\text { Question } 13 \text { bC2. How do you transport the [vehicle/ } \\
\text { equipment] on public roads? Is it ...? } \\
\text { Loaded }\end{array}$ & $1=$ Yes \\
\hline 2 & 34 & Q13bC3 & 1 & $\begin{array}{l}\text { Question } 13 \mathrm{bC} 3 . \text { How do you transport the [vehicle/ } \\
\text { equipment] on public roads? Is it ...? } \\
\text { Towed }\end{array}$ & $1=$ Yes \\
\hline
\end{tabular}




\begin{tabular}{|c|c|c|c|c|c|}
\hline $\begin{array}{l}1 \\
\text { k } \\
\text { 1) }\end{array}$ & $(01,(s)$ & I IKI UB। F & $\begin{array}{l}\text { ì } \\
\text { in } \\
\text { in }\end{array}$ & 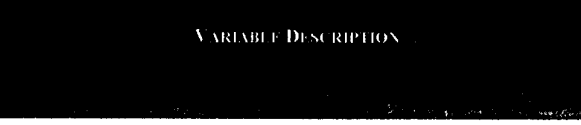 & 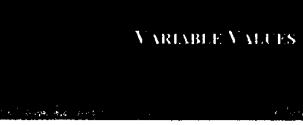 \\
\hline 2 & $35-36$ & Q13bC4 & 2 & $\begin{array}{l}\text { Question } 13 \mathrm{bC} 4 \text {. How do you transport the [vehicle/ } \\
\text { equipment] on public roads? Is it ...? } \\
\text { Transported some other way }\end{array}$ & No values \\
\hline 2 & 37 & Q13cA & 1 & $\begin{array}{l}\text { Question 13cA. Would you tell me what types of farm } \\
\text { vehicles or pieces of farm equipment you, or individuals } \\
\text { who help you, either drive or transport on public roads? } \\
\text { Harvester }\end{array}$ & $1=$ Yes \\
\hline 2 & $38-41$ & Q13cB1 & 4 & $\begin{array}{l}\text { Question } 13 \mathrm{cB1} \text {. In what year was your oldest } \\
\text { [vehicle/equipment] manufactured? }\end{array}$ & $\begin{array}{c}\text { Values }=1950-2002 \text { Year } \\
\text { manufactured }\end{array}$ \\
\hline 2 & $42-45$ & Q13cB2 & 4 & $\begin{array}{l}\text { Question 13cB2. In what year was your newest } \\
\text { [vehicle/equipment] manufactured? }\end{array}$ & $\begin{array}{c}\text { Values }=1950-2002 \text { Year } \\
\text { manufactured }\end{array}$ \\
\hline 2 & 46 & $\mathrm{Q} 13 \mathrm{cCl}$ & 1 & $\begin{array}{l}\text { Question } 13 \mathrm{cCl} \text {. How do you transport the [vehicle/ } \\
\text { equipment] on public roads? Is it ...? } \\
\text { Driven }\end{array}$ & $1=$ Yes \\
\hline 2 & 47 & $\mathrm{Q} 13 \mathrm{cC2}$ & 1 & $\begin{array}{l}\text { Question 13cC2. How do you transport the [vehicle/ } \\
\text { equipment] on public roads? Is it ...? } \\
\text { Loaded }\end{array}$ & $1=$ Yes \\
\hline 2 & 48 & Q13cC3 & 1 & $\begin{array}{l}\text { Question 13cC3. How do you transport the [vehicle/ } \\
\text { equipment] on public roads? Is it ...? } \\
\text { Towed }\end{array}$ & $1=$ Yes \\
\hline 2 & $49-50$ & $\mathrm{Q} 13 \mathrm{cC} 4$ & 2 & $\begin{array}{l}\text { Question 13cC4. How do you transport the [vehicle/ } \\
\text { equipment] on public roads? Is it ...? } \\
\text { Transported some other way }\end{array}$ & No values \\
\hline 2 & 51 & Q13dA & 1 & $\begin{array}{l}\text { Question 13dA. Would you tell me what types of farm } \\
\text { vehicles or pieces of farm equipment you, or individuals } \\
\text { who help you, either drive or transport on public roads? } \\
\text { Specialty attachment }\end{array}$ & $1=$ Yes \\
\hline 2 & $52-55$ & Q13dB1 & 4 & $\begin{array}{l}\text { Question 13dB1. In what year was your oldest } \\
\text { [vehicle/equipment] manufactured? }\end{array}$ & $\begin{array}{c}\text { Values }=1920-2002 \text { Year } \\
\text { manufactured }\end{array}$ \\
\hline 2 & $56-59$ & Q13dB2 & 4 & $\begin{array}{l}\text { Question 13dB2. In what year was your newest } \\
\text { [vehicle/equipment] manufactured? }\end{array}$ & $\begin{array}{c}\text { Values }=1950-2003 \text { Year } \\
\text { manufactured }\end{array}$ \\
\hline 2 & 60 & Q13dC1 & 1 & $\begin{array}{l}\text { Question } 13 \mathrm{dCl} \text {. How do you transport the [vehicle/ } \\
\text { equipment] on public roads? Is it ...? } \\
\text { Driven }\end{array}$ & $1=$ Yes \\
\hline 2 & 61 & Q13dC2 & 1 & $\begin{array}{l}\text { Question } 13 \mathrm{dC} 2 . \text { How do you transport the [vehicle/ } \\
\text { equipment] on public roads? Is it ...? } \\
\text { Loaded }\end{array}$ & $1=$ Yes \\
\hline 2 & 62 & Q13dC3 & 1 & $\begin{array}{l}\text { Question 13dC3. How do you transport the [vehicle/ } \\
\text { equipment] on public roads? Is it ...? } \\
\text { Towed }\end{array}$ & $1=$ Yes \\
\hline 2 & $63-64$ & Q13dC4 & 2 & $\begin{array}{l}\text { Question 13dC4. How do you transport the [vehicle/ } \\
\text { equipment] on public roads? Is it ...? } \\
\text { Transported some other way }\end{array}$ & No values \\
\hline
\end{tabular}




\begin{tabular}{|c|c|c|c|c|c|}
\hline $\begin{array}{l}c \\
i \\
13 \\
3\end{array}$ & $\operatorname{col}(s)$ & I.RIDBI: & i. & ( IRI UBi. I)ST RIPIKO & 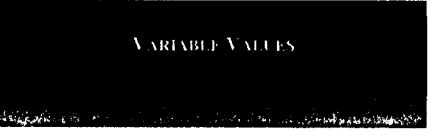 \\
\hline 2 & 65 & Q13eA & 1 & $\begin{array}{l}\text { Question 13eA. Would you tell me what types of farm } \\
\text { vehicles or pieces of farm equipment you, or individuals } \\
\text { who help you, either drive or transport on public roads? } \\
\text { Pickup truck }\end{array}$ & $1=$ Yes \\
\hline 2 & $66-69$ & Q13eB1 & 4 & $\begin{array}{l}\text { Question 13eB1. In what year was your oldest } \\
\text { [vehicle/equipment] manufactured? }\end{array}$ & $\begin{array}{c}\text { Values }=1950-2002 \text { Year } \\
\text { manufactured }\end{array}$ \\
\hline 2 & $70-73$ & Q13eB2 & 4 & $\begin{array}{l}\text { Question 13eB2. In what year was your newest } \\
\text { [vehicle/equipment] manufactured? }\end{array}$ & $\begin{array}{l}\text { Values }=1964-2003 \text { Year } \\
\text { manufactured }\end{array}$ \\
\hline 2 & 74 & $\mathrm{Q} 13 \mathrm{eCl}$ & 1 & $\begin{array}{l}\text { Question } 13 \mathrm{eC} 1 . \text { How do you transport the [vehicle/ } \\
\text { equipment] on public roads? Is it ...? } \\
\text { Driven }\end{array}$ & $1=$ Yes \\
\hline 2 & 75 & $\mathrm{Q} 13 \mathrm{eC} 2$ & 1 & $\begin{array}{l}\text { Question } 13 \mathrm{eC} 2 . \text { How do you transport the [vehicle/ } \\
\text { equipment] on public roads? Is it ...? } \\
\text { Loaded }\end{array}$ & $1=$ Yes \\
\hline 2 & 76 & Q13eC3 & 1 & $\begin{array}{l}\text { Question } 13 \mathrm{eC} 3 . \text { How do you transport the [vehicle/ } \\
\text { equipment] on public roads? Is it ...? } \\
\text { Towed }\end{array}$ & $1=$ Yes \\
\hline 2 & $77-78$ & Q13eC4 & 2 & $\begin{array}{l}\text { Question 13eC4. How do you transport the [vehicle/ } \\
\text { equipment] on public roads? Is it ...? } \\
\text { Transported some other way }\end{array}$ & No values \\
\hline 3 & $1-5$ & ID3 & 5 & Identification Number - Card Three & Values $=00010-14762$ \\
\hline 3 & 6 & CARD3 & 1 & Card Number - Card Three & CARD3 always $=3$ \\
\hline 3 & 7 & Q13fA & 1 & $\begin{array}{l}\text { Question 13fA. Would you tell me what types of farm } \\
\text { vehicles or pieces of farm equipment you, or individuals } \\
\text { who help you, either drive or transport on public roads? } \\
\text { Dump truck ( } 2 \text { ton) }\end{array}$ & $1=$ Yes \\
\hline 3 & 8-11 & Q13fB1 & 4 & $\begin{array}{l}\text { Question } 13 \mathrm{fBl} \text {. In what year was your oldest } \\
\text { [vehicle/equipment] manufactured? }\end{array}$ & $\begin{array}{l}\text { Values }=1949-2001 \text { Year } \\
\text { manufactured }\end{array}$ \\
\hline 3 & $12-15$ & Q13fB2 & 4 & $\begin{array}{l}\text { Question 13fB2. In what year was your newest } \\
\text { [vehicle/equipment] manufactured? }\end{array}$ & $\begin{array}{c}\text { Values }=1954-2003 \text { Year } \\
\text { manufactured }\end{array}$ \\
\hline 3 & 16 & Q13fCl & 1 & $\begin{array}{l}\text { Question } 13 \mathrm{fC} 1 \text {. How do you transport the [vehicle/ } \\
\text { equipment] on public roads? Is it ...? } \\
\text { Driven }\end{array}$ & $1=$ Yes \\
\hline 3 & 17 & Q13fC2 & 1 & $\begin{array}{l}\text { Question } 13 \mathrm{fC} 2 . \text { How do you transport the [vehicle/ } \\
\text { equipment] on public roads? Is it ...? } \\
\text { Loaded }\end{array}$ & $1=$ Yes \\
\hline 3 & 18 & Q13fC3 & 1 & $\begin{array}{l}\text { Question } 13 \mathrm{fC} 3 . \text { How do you transport the [vehicle/ } \\
\text { equipment] on public roads? Is it ...? } \\
\text { Towed }\end{array}$ & $1=$ Yes \\
\hline 3 & $19-20$ & Q13fC4 & 2 & $\begin{array}{l}\text { Question } 13 \mathrm{fC} 4 . \text { How do you transport the [vehicle/ } \\
\text { equipment] on public roads? Is it ...? } \\
\text { Transported some other way }\end{array}$ & No values \\
\hline
\end{tabular}




\begin{tabular}{|c|c|c|c|c|c|}
\hline $\begin{array}{l}c \\
i \\
k \\
1\end{array}$ & (olls) & I IRI \BI.1: & $\begin{array}{c}1 . \\
\vdots \\
i \\
i \\
i\end{array}$ & 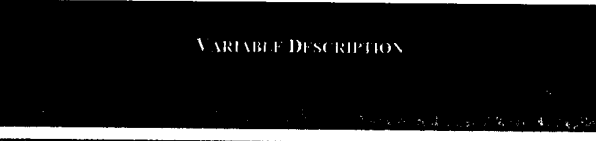 & 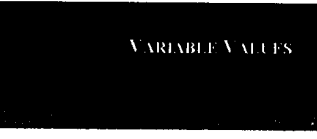 \\
\hline 3 & 21 & Q13gA & 1 & $\begin{array}{l}\text { Question 13gA. Would you tell me what types of farm } \\
\text { vehicles or pieces of farm equipment you, or individuals } \\
\text { who help you, either drive or transport on public roads? } \\
\text { Hay baler }\end{array}$ & $1=$ Yes \\
\hline 3 & $22-25$ & Q13gB1 & 4 & $\begin{array}{l}\text { Question 13gB1. In what year was your oldest } \\
\text { [vehicle/equipment] manufactured? }\end{array}$ & $\begin{array}{c}\text { Values }=1949-2003 \text { Year } \\
\text { manufactured }\end{array}$ \\
\hline 3 & $26-29$ & Q13gB2 & 4 & $\begin{array}{l}\text { Question 13gB2. In what year was your newest } \\
\text { [vehicle/equipment] manufactured? }\end{array}$ & $\begin{array}{l}\text { Values }=1950-2003 \text { Year } \\
\text { manufactured }\end{array}$ \\
\hline 3 & 30 & Q13gC1 & 1 & $\begin{array}{l}\text { Question } 13 \mathrm{gCl} \text {. How do you transport the [vehicle/ } \\
\text { equipment] on public roads? Is it ...? } \\
\text { Driven }\end{array}$ & $1=$ Yes \\
\hline 3 & 31 & Q13gC2 & 1 & $\begin{array}{l}\text { Question 13gC2. How do you transport the [vehicle/ } \\
\text { equipment] on public roads? Is it ...? } \\
\text { Loaded }\end{array}$ & $1=$ Yes \\
\hline 3 & 32 & Q13gC3 & 1 & $\begin{array}{l}\text { Question } 13 \mathrm{gC} 3 \text {. How do you transport the [vehicle/ } \\
\text { equipment] on public roads? Is it ...? } \\
\text { Towed }\end{array}$ & $1=$ Yes \\
\hline 3 & $33-34$ & Q13gC4 & 2 & $\begin{array}{l}\text { Question } 13 \mathrm{gC} 4 . \text { How do you transport the [vehicle/ } \\
\text { equipment] on public roads? Is it ...? } \\
\text { Transported some other way }\end{array}$ & No values \\
\hline 3 & $35-36$ & Q13hA1 & 2 & $\begin{array}{l}\text { Question 13hAl. Would you tell me what types of farm } \\
\text { vehicles or pieces of farm equipment you, or individuals } \\
\text { who help you, either drive or transport on public roads? } \\
\text { First other type }\end{array}$ & $\begin{array}{l}01=\text { Front end loader } \\
02=\text { Trailer } \\
03=\text { Mower } \\
04=\text { Tiller } \\
05=\text { Four wheeler } \\
06=\text { Cattle trailer } \\
07=\text { Back hoe } \\
08=\text { Bush hog } \\
09=\text { Hay rake/disc/spear } \\
10=\text { Sprayer } \\
11=\text { Planter } \\
12=\text { Corn picker } \\
13=\text { Fertilizer } \\
14=\text { Plow } \\
15=\text { Spreader } \\
16=\text { Bob cat } \\
17=\text { Cotton picker } \\
18=\text { Horse trailer } \\
19=\text { Disc harrow } \\
20=\text { Grain trailer } \\
21=\text { Fork lift } \\
22=\text { Tobacco primer } \\
23=\text { Wagon }\end{array}$ \\
\hline 3 & 37 & Q13hA & 1 & $\begin{array}{l}\text { Question 13hA. Would you tell me what types of farm } \\
\text { vehicles or pieces of farm equipment you, or individuals } \\
\text { who help you, either drive or transport on public roads? } \\
\text { First other mentioned }\end{array}$ & $1=$ Yes \\
\hline 3 & $38-41$ & Q13hB1 & 4 & $\begin{array}{l}\text { Question 13hB1. In what year was your oldest } \\
\text { [vehicle/equipment] manufactured? }\end{array}$ & $\begin{array}{c}\text { Values }=1956-2003 \text { Year } \\
\text { manufactured }\end{array}$ \\
\hline
\end{tabular}




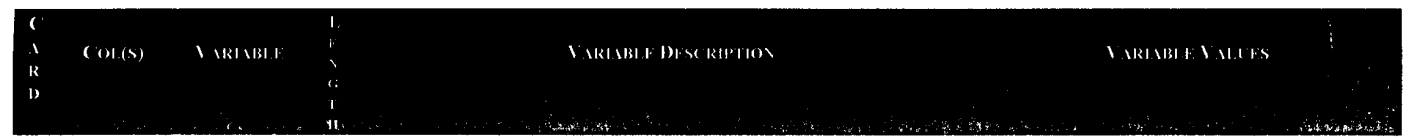

\begin{tabular}{|c|c|c|c|c|c|}
\hline 3 & $42-45$ & $\mathrm{Q} 13 \mathrm{hB} 2$ & 4 & $\begin{array}{l}\text { Question 13hB2. In what year was your newest } \\
\text { [vehicle/equipment] manufactured? }\end{array}$ & $\begin{array}{c}\text { Values }=1958-2003 \text { Year } \\
\text { manufactured }\end{array}$ \\
\hline 3 & 46 & Q13hCl & 1 & $\begin{array}{l}\text { Question } 13 \mathrm{hCl} \text {. How do you transport the [vehicle/ } \\
\text { equipment] on public roads? Is it ...? } \\
\text { Driven }\end{array}$ & $1=$ Yes \\
\hline 3 & 47 & Q13hC2 & 1 & $\begin{array}{l}\text { Question } 13 \mathrm{hC} 2 \text {. How do you transport the [vehicle/ } \\
\text { equipment] on public roads? Is it ...? } \\
\text { Loaded }\end{array}$ & $1=$ Yes \\
\hline 3 & 48 & Q13hC3 & 1 & $\begin{array}{l}\text { Question 13hC3. How do you transport the [vehicle/ } \\
\text { equipment] on public roads? Is it ...? } \\
\text { Towed }\end{array}$ & $1=$ Yes \\
\hline 3 & $49-50$ & Q13hC4 & 2 & $\begin{array}{l}\text { Question } 13 \mathrm{hC} 4 . \text { How do you transport the [vehicle/ } \\
\text { equipment] on public roads? Is it ...? } \\
\text { Transported some other way }\end{array}$ & No values \\
\hline 3 & $51-52$ & Q13iA1 & 2 & $\begin{array}{l}\text { Question 13iA1. Would you tell me what types of farm } \\
\text { vehicles or pieces of farm equipment you, or individuals } \\
\text { who help you, either drive or transport on public roads? } \\
\text { Second other type }\end{array}$ & $\begin{array}{l}01=\text { Front end loader } \\
02=\text { Trailer } \\
03=\text { Mower } \\
04=\text { Tiller } \\
05=\text { Four wheeler } \\
06=\text { Cattle trailer } \\
07=\text { Back hoe } \\
08=\text { Bush hog } \\
09=\text { Hay rake/disc/spear } \\
10=\text { Sprayer } \\
11=\text { Planter } \\
12=\text { Corn picker } \\
13=\text { Fertilizer } \\
14=\text { Plow } \\
15=\text { Spreader } \\
16=\text { Bob cat } \\
17=\text { Cotton picker } \\
18=\text { Horse trailer } \\
19=\text { Disc harrow } \\
20=\text { Grain trailer } \\
21=\text { Fork lift } \\
22=\text { Tobacco primer } \\
23=\text { Wagon }\end{array}$ \\
\hline 3 & 53 & Q13iA & 1 & $\begin{array}{l}\text { Question } 13 \mathrm{iA} \text {. Would you tell me what types of farm } \\
\text { vehicles or pieces of farm equipment you, or individuals } \\
\text { who help you, either drive or transport on public roads? } \\
\text { Second other mentioned }\end{array}$ & $1=$ Yes \\
\hline 3 & $54-57$ & Q13iB1 & 4 & $\begin{array}{l}\text { Question } 13 \text { iB1. In what year was your oldest } \\
\text { [vehicle/equipment] manufactured? }\end{array}$ & $\begin{array}{c}\text { Values }=1956-2002 \text { Year } \\
\text { manufactured }\end{array}$ \\
\hline 3 & $58-61$ & Q13iB2 & 4 & $\begin{array}{l}\text { Question 13iB2. In what year was your newest } \\
\text { [vehicle/equipment] manufactured? }\end{array}$ & $\begin{array}{l}\text { Values }=1960-2002 \text { Year } \\
\text { manufactured }\end{array}$ \\
\hline 3 & 62 & Q13iCl & 1 & $\begin{array}{l}\text { Question } 13 \mathrm{iCl} \text {. How do you transport the [vehicle/ } \\
\text { equipment] on public roads? Is it ...? } \\
\text { Driven }\end{array}$ & $1=$ Yes \\
\hline
\end{tabular}




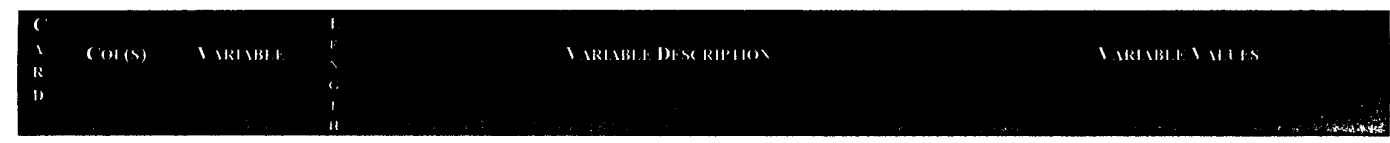

\begin{tabular}{|c|c|c|c|c|c|}
\hline 3 & 63 & Q13iC2 & 1 & $\begin{array}{l}\text { Question } 13 \mathrm{iC} 2 \text {. How do you transport the [vehicle/ } \\
\text { equipment] on public roads? Is it ...? } \\
\text { Loaded }\end{array}$ & $1=$ Yes \\
\hline 3 & 64 & Q13iC3 & 1 & $\begin{array}{l}\text { Question 13iC3. How do you transport the [vehicle/ } \\
\text { equipment] on public roads? Is it ...? } \\
\text { Towed }\end{array}$ & $1=$ Yes \\
\hline 3 & 65-66 & Q13iC4 & 2 & $\begin{array}{l}\text { Question 13iC4. How do you transport the [vehicle/ } \\
\text { equipment] on public roads? Is it ...? } \\
\text { Transported some other way }\end{array}$ & No values \\
\hline 4 & $1-5$ & ID4 & 5 & Identification Number - Card Four & Values $=00010-14762$ \\
\hline 4 & 6 & CARD4 & 1 & Card Number - Card Four & CARD4 always $=4$ \\
\hline 4 & 7 & Q14A1 & 1 & $\begin{array}{l}\text { Question 14A1. During which months of the year do } \\
\text { you do the least amount of farm work in the fields? } \\
\text { January }\end{array}$ & $\mathrm{I}=$ Mentioned \\
\hline 4 & 8 & Q14A2 & 1 & $\begin{array}{l}\text { Question 14A2. During which months of the year do } \\
\text { you do the most amount of farm work in the fields? } \\
\text { January }\end{array}$ & $1=$ Mentioned \\
\hline 4 & 9 & Q14B1 & 1 & $\begin{array}{l}\text { Question 14B1. During which months of the year do } \\
\text { you do the least amount of farm work in the fields? } \\
\text { February }\end{array}$ & $1=$ Mentioned \\
\hline 4 & 10 & Q14B2 & 1 & $\begin{array}{l}\text { Question 14B2. During which months of the year do } \\
\text { you do the most amount of farm work in the fields? } \\
\text { February }\end{array}$ & $1=$ Mentioned \\
\hline 4 & 11 & Q14C1 & 1 & $\begin{array}{l}\text { Question } 14 \mathrm{Cl} \text {. During which months of the year do } \\
\text { you do the least amount of farm work in the fields? } \\
\text { March }\end{array}$ & $1=$ Mentioned \\
\hline 4 & 12 & Q14C2 & 1 & $\begin{array}{l}\text { Question 14C2. During which months of the year do } \\
\text { you do the most amount of farm work in the fields? } \\
\text { March }\end{array}$ & $1=$ Mentioned \\
\hline 4 & 13 & Q14D1 & 1 & $\begin{array}{l}\text { Question 14DI. During which months of the year do } \\
\text { you do the least amount of farm work in the fields? } \\
\text { April }\end{array}$ & $1=$ Mentioned \\
\hline 4 & 14 & Q14D2 & 1 & $\begin{array}{l}\text { Question 14D2. During which months of the year do } \\
\text { you do the most amount of farm work in the fields? } \\
\text { April }\end{array}$ & $1=$ Mentioned \\
\hline 4 & 15 & Q14E1 & 1 & $\begin{array}{l}\text { Question 14E1. During which months of the year do } \\
\text { you do the least amount of farm work in the fields? } \\
\text { May }\end{array}$ & $1=$ Mentioned \\
\hline 4 & 16 & Q14E2 & 1 & $\begin{array}{l}\text { Question 14E2. During which months of the year do } \\
\text { you do the most amount of farm work in the fields? } \\
\text { May }\end{array}$ & $1=$ Mentioned \\
\hline
\end{tabular}




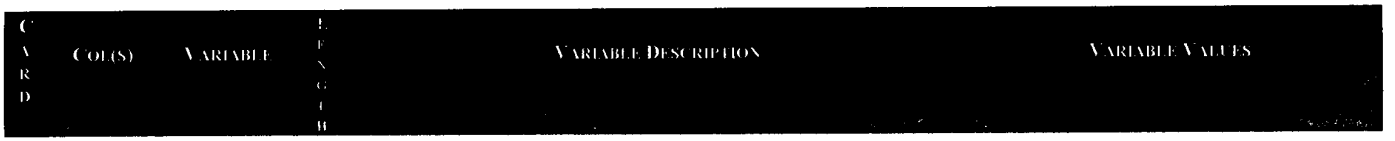

\begin{tabular}{|c|c|c|c|c|c|}
\hline 4 & 17 & Q14F1 & 1 & $\begin{array}{l}\text { Question 14F1. During which months of the year do } \\
\text { you do the least amount of farm work in the fields? } \\
\text { June }\end{array}$ & $1=$ Mentioned \\
\hline 4 & 18 & Q14F2 & 1 & $\begin{array}{l}\text { Question 14F2. During which months of the year do } \\
\text { you do the most amount of farm work in the fields? } \\
\text { June }\end{array}$ & $1=$ Mentioned \\
\hline 4 & 19 & Q14G1 & 1 & $\begin{array}{l}\text { Question 14G1. During which months of the year do } \\
\text { you do the least amount of farm work in the fields? } \\
\text { July }\end{array}$ & $1=$ Mentioned \\
\hline 4 & 20 & Q14G2 & 1 & $\begin{array}{l}\text { Question 14G2. During which months of the year do } \\
\text { you do the most amount of farm work in the fields? } \\
\text { July }\end{array}$ & $1=$ Mentioned \\
\hline 4 & 21 & Q14H1 & 1 & $\begin{array}{l}\text { Question 14H1. During which months of the year do } \\
\text { you do the least amount of farm work in the fields? } \\
\text { August }\end{array}$ & $1=$ Mentioned \\
\hline 4 & 22 & Q14H2 & 1 & $\begin{array}{l}\text { Question 14H2. During which months of the year do } \\
\text { you do the most amount of farm work in the fields? } \\
\text { August }\end{array}$ & $1=$ Mentioned \\
\hline 4 & 23 & Q14I1 & 1 & $\begin{array}{l}\text { Question 14I1. During which months of the year do you } \\
\text { do the least amount of farm work in the fields? } \\
\text { September }\end{array}$ & $1=$ Mentioned \\
\hline 4 & 24 & Q1412 & 1 & $\begin{array}{l}\text { Question 14I2. During which months of the year do you } \\
\text { do the most amount of farm work in the fields? } \\
\text { September }\end{array}$ & $1=$ Mentioned \\
\hline 4 & 25 & Q14J1 & 1 & $\begin{array}{l}\text { Question 14J1. During which months of the year do you } \\
\text { do the least amount of farm work in the fields? } \\
\text { October }\end{array}$ & $1=$ Mentioned \\
\hline$\overline{4}$ & 26 & Q14J2 & 1 & $\begin{array}{l}\text { Question 14J2. During which months of the year do you } \\
\text { do the most amount of farm work in the fields? } \\
\text { October }\end{array}$ & $1=$ Mentioned \\
\hline 4 & 27 & Q14K1 & 1 & $\begin{array}{l}\text { Question 14K1. During which months of the year do } \\
\text { you do the least amount of farm work in the fields? } \\
\text { November }\end{array}$ & $1=$ Mentioned \\
\hline 4 & 28 & Q14K2 & 1 & $\begin{array}{l}\text { Question 14K2. During which months of the year do } \\
\text { you do the most amount of farm work in the fields? } \\
\text { November }\end{array}$ & $1=$ Mentioned \\
\hline 4 & 29 & Q14L1 & 1 & $\begin{array}{l}\text { Question 14L1. During which months of the year do } \\
\text { you do the least amount of farm work in the fields? } \\
\text { December }\end{array}$ & $1=$ Mentioned \\
\hline 4 & 30 & Q14L2 & 1 & $\begin{array}{l}\text { Question 14L2. During which months of the year do } \\
\text { you do the most amount of farm work in the fields? } \\
\text { December }\end{array}$ & $1=$ Mentioned \\
\hline
\end{tabular}




\begin{tabular}{|c|c|c|c|c|c|}
\hline $\begin{array}{l}c \\
1 \\
R \\
1\end{array}$ & (ans) & 1. . & $\begin{array}{c}1 . \\
\vdots \\
\vdots \\
\vdots \\
11\end{array}$ & 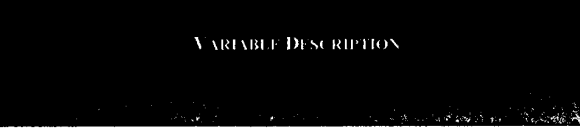 & I VRIUBII I WATS \\
\hline 4 & $31-32$ & Q15A & 2 & $\begin{array}{l}\text { Question 15A. On a typical day, how many hours do } \\
\text { you work on the farm during slow months? }\end{array}$ & $\begin{array}{l}\text { Values }=1-15 \text { Hours } \\
0=\text { No hours worked }\end{array}$ \\
\hline 4 & $33-34$ & Q15B & 2 & $\begin{array}{l}\text { Question } 15 \mathrm{~B} \text {. On a typical day, how many hours do } \\
\text { you work on the farm during busy months? }\end{array}$ & Values $=3-18$ Hours \\
\hline 4 & 35 & Q16A & 1 & $\begin{array}{l}\text { Question 16A. In a typical week, how many days do } \\
\text { you work on the farm during slow months? }\end{array}$ & $\begin{array}{l}\text { Values }=1-7 \text { Days } \\
0=\text { No days worked }\end{array}$ \\
\hline 4 & 36 & Q16B & 1 & $\begin{array}{l}\text { Question 16B. In a typical week, how many days do } \\
\text { you work on the farm during busy months? }\end{array}$ & Values $=3-7$ Days \\
\hline 4 & $37-39$ & Q17A & 3 & $\begin{array}{l}\text { Question 17A. How many hours per week do you drive } \\
\text { farm vehicles on the farm during slow months? }\end{array}$ & $\begin{array}{l}\text { Values }=1-42 \text { Hours } \\
0=\text { No hours driven }\end{array}$ \\
\hline 4 & $40-42$ & Q17B & 3 & $\begin{array}{l}\text { Question 17B. How many hours per week do you drive } \\
\text { farm vehicles on the farm during busy months? }\end{array}$ & $\begin{array}{l}\text { Values }=2-70 \text { Hours } \\
0=\text { No hours driven }\end{array}$ \\
\hline 4 & $43-45$ & Q18A & 3 & $\begin{array}{l}\text { Question } 18 \mathrm{~A} \text {. How many hours per week do you drive } \\
\text { farm vehicles on public roads during slow months? }\end{array}$ & $\begin{array}{l}\text { Values }=1-20 \text { Hours } \\
0=\text { No hours driven }\end{array}$ \\
\hline 4 & $46-48$ & Q18B & 3 & $\begin{array}{l}\text { Question 18B. How many hours per week do you drive } \\
\text { farm vehicles on public roads during buy months? }\end{array}$ & Values $=1-70$ Hours \\
\hline 4 & $49-50$ & Q19 & 2 & $\begin{array}{l}\text { Question 19. What is the average speed of your farm } \\
\text { vehicles or equipment when traveling on public roads? }\end{array}$ & Values $=5-60$ Miles per hour \\
\hline 4 & $51-53$ & Q20A & 3 & $\begin{array}{l}\text { Question } 20 \mathrm{~A} \text {. How many cars and trucks would you } \\
\text { say you or your help meet on the road per day when } \\
\text { driving farm vehicles on public roads during slow } \\
\text { months? }\end{array}$ & $\begin{array}{l}\text { Values }=1-200 \text { Cars and trucks } \\
0=\text { No cars met }\end{array}$ \\
\hline 4 & $54-56$ & Q20B & 3 & $\begin{array}{l}\text { Question 20B. How many cars and trucks would you } \\
\text { say you or your help meet on the road per day when } \\
\text { driving farm vehicles on public roads during busy } \\
\text { months? }\end{array}$ & Values $=1-300$ Cars and trucks \\
\hline 4 & $57-59$ & Q21A & 3 & $\begin{array}{l}\text { Question 21A. How many of those cars and trucks that } \\
\text { you meet on the road would you say make you feel like } \\
\text { you could end up in a crash during slow months? }\end{array}$ & $\begin{array}{l}\text { Values }=1-50 \text { Cars and trucks } \\
0=\text { No cars met }\end{array}$ \\
\hline 4 & $60-62$ & Q21B & 3 & $\begin{array}{l}\text { Question 21B. How many of those cars and trucks that } \\
\text { you meet on the road would you say make you feel like } \\
\text { you could end up in a crash during busy months? }\end{array}$ & $\begin{array}{l}\text { Values }=1-180 \text { Cars and trucks } \\
0=\text { No cars met }\end{array}$ \\
\hline 4 & $63-65$ & Q22A & 3 & $\begin{array}{l}\text { Question } 22 \mathrm{~A} \text {. How many of those cars and trucks that } \\
\text { your help meets on the road would you say makes them } \\
\text { feel like they could end up in a crash during slow } \\
\text { months? }\end{array}$ & $\begin{array}{l}\text { Values }=1-65 \text { Cars and trucks } \\
0=\text { No cars met } \\
995=\text { NA }- \text { No help/no help used }\end{array}$ \\
\hline 4 & $66-68$ & Q22B & 3 & $\begin{array}{l}\text { Question 22B. How many of those cars and trucks that } \\
\text { your help meets on the road would you say makes them } \\
\text { feel like they could end up in a crash during busy } \\
\text { months? }\end{array}$ & $\begin{array}{l}\text { Values }=1-150 \text { Cars and trucks } \\
0=\text { No cars met }\end{array}$ \\
\hline 4 & 69 & Q23 & 1 & $\begin{array}{l}\text { Question } 23 \text {. Over the last ten years, would you say the } \\
\text { number of times you or your help felt like you could } \\
\text { have ended up in a crash driving farm vehicles on public } \\
\text { roads has ...? }\end{array}$ & $\begin{array}{l}1=\text { Decreased } \\
2=\text { Stayed about the same } \\
3=\text { Increased } \\
4=\text { Increased a lot } \\
5=\text { Increased so much I avoid driving } \\
\quad \text { on public roads }\end{array}$ \\
\hline 4 & $70-72$ & Q24 & 3 & $\begin{array}{l}\text { Question } 24 \text {. How many times during } 2002 \text { did you feel } \\
\text { like you could have ended up in a crash when driving } \\
\text { farm vehicles on public roads? }\end{array}$ & $\begin{array}{l}\text { Values }=1-200 \text { Times } \\
0=\text { No time }\end{array}$ \\
\hline 4 & $73-75$ & Q25 & 3 & $\begin{array}{l}\text { Question } 25 \text {. How many times during } 2002 \text { did your } \\
\text { help feel like you could have ended up in a crash when } \\
\text { driving farm vehicles on public roads? }\end{array}$ & $\begin{array}{l}\text { Values }=1-150 \text { Times } \\
0=\text { No time } \\
995=\text { NA }- \text { No help/no help used }\end{array}$ \\
\hline
\end{tabular}




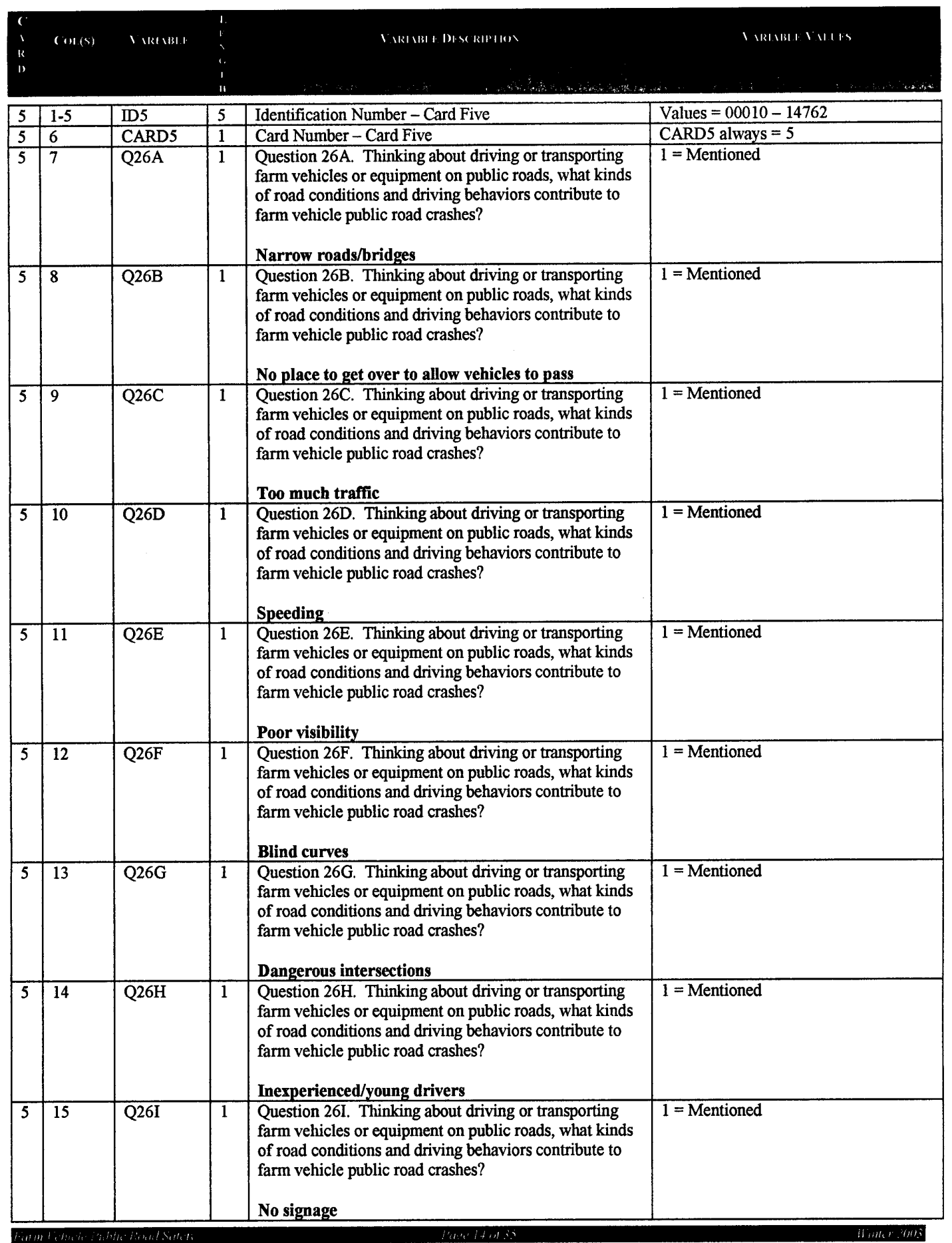




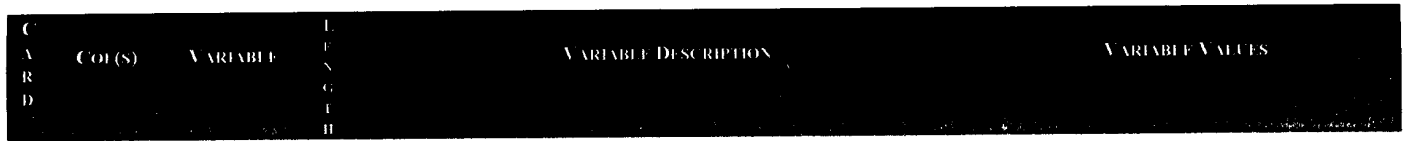

\begin{tabular}{|c|c|c|c|c|c|}
\hline 5 & 16 & Q26J & 1 & $\begin{array}{l}\text { Question 26J. Thinking about driving or transporting } \\
\text { farm vehicles or equipment on public roads, what kinds } \\
\text { of road conditions and driving behaviors contribute to } \\
\text { farm vehicle public road crashes? } \\
\text { Lack of non-farm vehicle driver knowledge }\end{array}$ & $1=$ Mentioned \\
\hline 5 & 17 & Q26K & 1 & $\begin{array}{l}\text { Question } 26 \mathrm{~K} \text {. Thinking about driving or transporting } \\
\text { farm vehicles or equipment on public roads, what kinds } \\
\text { of road conditions and driving behaviors contribute to } \\
\text { farm vehicle public road crashes? } \\
\text { No road signs alerting non-farm vehicle drivers to } \\
\text { farm vehicles sharing the road }\end{array}$ & $1=$ Mentioned \\
\hline 5 & 18 & Q26L & 1 & $\begin{array}{l}\text { Question } 26 \mathrm{~L} \text {. Thinking about driving or transporting } \\
\text { farm vehicles or equipment on public roads, what kinds } \\
\text { of road conditions and driving behaviors contribute to } \\
\text { farm vehicle public road crashes? } \\
\text { Pot holes }\end{array}$ & $1=$ Mentioned \\
\hline 5 & 19 & Q26M & 1 & $\begin{array}{l}\text { Question } 26 \mathrm{M} \text {. Thinking about driving or transporting } \\
\text { farm vehicles or equipment on public roads, what kinds } \\
\text { of road conditions and driving behaviors contribute to } \\
\text { farm vehicle public road crashes? } \\
\text { Drivers passing when it is not safe }\end{array}$ & $1=$ Mentioned \\
\hline 5 & 20 & Q26N & 1 & $\begin{array}{l}\text { Question } 26 \mathrm{~N} \text {. Thinking about driving or transporting } \\
\text { farm vehicles or equipment on public roads, what kinds } \\
\text { of road conditions and driving behaviors contribute to } \\
\text { farm vehicle public road crashes? } \\
\text { No turn lanes }\end{array}$ & $1=$ Mentioned \\
\hline 5 & 21 & Q260 & 1 & $\begin{array}{l}\text { Question } 260 \text {. Thinking about driving or transporting } \\
\text { farm vehicles or equipment on public roads, what kinds } \\
\text { of road conditions and driving behaviors contribute to } \\
\text { farm vehicle public road crashes? } \\
\text { Drivers don't understand hand signals }\end{array}$ & $1=$ Mentioned \\
\hline 5 & 22 & Q26P & 1 & $\begin{array}{l}\text { Question 26P. Thinking about driving or transporting } \\
\text { farm vehicles or equipment on public roads, what kinds } \\
\text { of road conditions and driving behaviors contribute to } \\
\text { farm vehicle public road crashes? } \\
\text { Impatient drivers }\end{array}$ & $1=$ Mentioned \\
\hline 5 & $23-24$ & Q26Q & 2 & $\begin{array}{l}\text { Question 26Q. Thinking about driving or transporting } \\
\text { farm vehicles or equipment on public roads, what kinds } \\
\text { of road conditions and driving behaviors contribute to } \\
\text { farm vehicle public road crashes? }\end{array}$ & $\begin{array}{l}01=\text { Bad weather } \\
02=\text { Carelessness, lack of caution } \\
03=\text { Speed limits too high } \\
04=\text { Secondary roads need repaired }, \\
\quad \text { roads not maintained } \\
05=\text { Extra wide/large equipment } \\
06=\text { Low shoulders } \\
07=\text { Mail/paper boxes too close to road } \\
08=\text { Drunk/drugged driver } \\
98=\text { Don't know }\end{array}$ \\
\hline
\end{tabular}




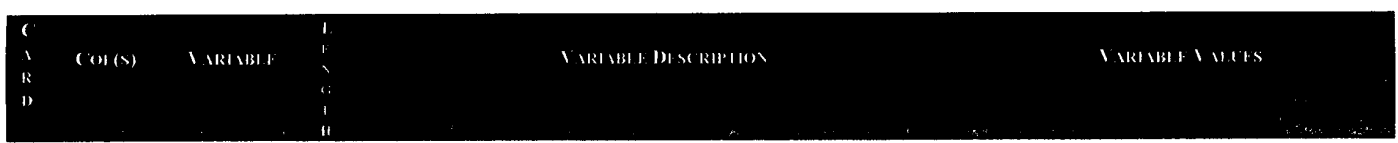

\begin{tabular}{|c|c|c|c|c|c|}
\hline 5 & $25-26$ & Q26R & 2 & $\begin{array}{l}\text { Question 26R. Thinking about driving or transporting } \\
\text { farm vehicles or equipment on public roads, what kinds } \\
\text { of road conditions and driving behaviors contribute to } \\
\text { farm vehicle public road crashes? } \\
\text { Second other condition }\end{array}$ & $\begin{array}{l}01=\text { Bad weather } \\
02=\text { Carelessness, lack of caution } \\
03=\text { Speed limits too high } \\
04=\text { Secondary roads need repaired }, \\
\quad \text { roads not maintained } \\
05=\text { Extra wide/large equipment } \\
06=\text { Low shoulders } \\
07=\text { Mail/paper boxes too close to road } \\
08=\text { Drunk } / \text { drugged driver } \\
98=\text { Don't know }\end{array}$ \\
\hline 5 & 27 & Q27A & 1 & $\begin{array}{l}\text { Question 27A. Thinking about driving farm vehicles on } \\
\text { public roads, what kind of things do or have you or your } \\
\text { help ever done to avoid being involved in a farm vehicle } \\
\text { public road crash? } \\
\text { Nothing in particular }\end{array}$ & $1=$ Mentioned \\
\hline 5 & 28 & Q27B & 1 & $\begin{array}{l}\text { Question 27B. Thinking about driving farm vehicles on } \\
\text { public roads, what kind of things do or have you or your } \\
\text { help ever done to avoid being involved in a farm vehicle } \\
\text { public road crash? } \\
\text { Transport equipment between fields using a low boy } \\
\text { (flat bed truck) }\end{array}$ & $1=$ Mentioned \\
\hline 5 & 29 & Q27C & 1 & $\begin{array}{l}\text { Question } 27 \mathrm{C} \text {. Thinking about driving farm vehicles on } \\
\text { public roads, what kind of things do or have you or your } \\
\text { help ever done to avoid being involved in a farm vehicle } \\
\text { public road crash? } \\
\text { Use lead or follow cars }\end{array}$ & $1=$ Mentioned \\
\hline 5 & 30 & Q27D & 1 & $\begin{array}{l}\text { Question 27D. Thinking about driving farm vehicles on } \\
\text { public roads, what kind of things do or have you or your } \\
\text { help ever done to avoid being involved in a farm vehicle } \\
\text { public road crash? } \\
\text { Sold some of my land }\end{array}$ & $1=$ Mentioned \\
\hline 5 & 31 & Q27E & 1 & $\begin{array}{l}\text { Question } 27 \text {. Thinking about driving farm vehicles on } \\
\text { public roads, what kind of things do or have you or your } \\
\text { help ever done to avoid being involved in a farm vehicle } \\
\text { public road crash? } \\
\text { Changed my crop/product mix }\end{array}$ & $1=$ Mentioned \\
\hline 5 & 32 & $\mathrm{Q} 27 \mathrm{~F}$ & 1 & $\begin{array}{l}\text { Question } 27 \mathrm{~F} \text {. Thinking about driving farm vehicles on } \\
\text { public roads, what kind of things do or have you or your } \\
\text { help ever done to avoid being involved in a farm vehicle } \\
\text { public road crash? } \\
\text { Leased out my land to someone else to farm }\end{array}$ & $1=$ Mentioned \\
\hline 5 & 33 & Q27G & 1 & $\begin{array}{l}\text { Question 27G. Thinking about driving farm vehicles on } \\
\text { public roads, what kind of things do or have you or your } \\
\text { help ever done to avoid being involved in a farm vehicle } \\
\text { public road crash? } \\
\text { Drove off the road to avoid a collision }\end{array}$ & $1=$ Mentioned \\
\hline
\end{tabular}




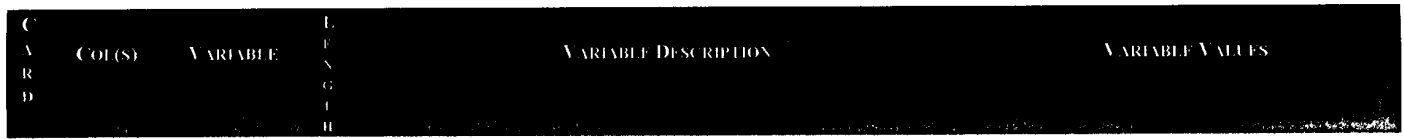

\begin{tabular}{|c|c|c|c|c|c|}
\hline 5 & 34 & Q27H & 1 & $\begin{array}{l}\text { Question } 27 \mathrm{H} \text {. Thinking about driving farm vehicles on } \\
\text { public roads, what kind of things do or have you or your } \\
\text { help ever done to avoid being involved in a farm vehicle } \\
\text { public road crash? } \\
\text { Put extra lighting and signage on my farm equipment }\end{array}$ & 1 = Mentioned \\
\hline 5 & 35 & Q27I & 1 & $\begin{array}{l}\text { Question 27I. Thinking about driving farm vehicles on } \\
\text { public roads, what kind of things do or have you or your } \\
\text { help ever done to avoid being involved in a farm vehicle } \\
\text { public road crash? } \\
\text { Spoke with my local transportation officials }\end{array}$ & $1=$ Mentioned \\
\hline 5 & 36 & Q27J & 1 & $\begin{array}{l}\text { Question 27J. Thinking about driving farm vehicles on } \\
\text { public roads, what kind of things do or have you or your } \\
\text { help ever done to avoid being involved in a farm vehicle } \\
\text { public road crash? } \\
\text { Requested road signs be put up }\end{array}$ & $1=$ Mentioned \\
\hline 5 & 37 & Q27K & 1 & $\begin{array}{l}\text { Question } 27 \mathrm{~K} \text {. Thinking about driving farm vehicles on } \\
\text { public roads, what kind of things do or have you or your } \\
\text { help ever done to avoid being involved in a farm vehicle } \\
\text { public road crash? } \\
\text { Had safety features installed such as mirrors, caution } \\
\text { lights }\end{array}$ & $1=$ Mentioned \\
\hline 5 & $38-39$ & Q27L & 2 & $\begin{array}{l}\text { Question 27L. Thinking about driving farm vehicles on } \\
\text { public roads, what kind of things do or have you or your } \\
\text { help ever done to avoid being involved in a farm vehicle } \\
\text { public road crash? }\end{array}$ & $\begin{array}{l}01=\text { Travel when traffic is light } \\
02=\text { Drive slower } \\
03=\text { Not overload/secure materials } \\
\quad \text { better } \\
04=\text { Stay off main road } \\
05=\text { Be very cautious/pay attention/be } \\
\quad \text { alert } \\
06=\text { Repair secondary roads/maintain } \\
\text { roads better } \\
07=\text { Pulled off/moved off road for } \\
\quad \text { other to pass } \\
08=\text { Safety chains on trailers } \\
09=\text { Don't travel on roads after dark } \\
10=\text { Maintain /inspect vehicle } \\
11=\text { Hired someone else to haul } \\
12=\text { Drive in middle of road to keep } \\
\quad \text { folks from passing }\end{array}$ \\
\hline
\end{tabular}




\begin{tabular}{|c|c|c|c|c|c|}
\hline $\begin{array}{l}3 \\
1 \\
13 \\
11\end{array}$ & Cols (s) & | IKINBII |: & $\begin{array}{c}1 \\
\vdots \\
i \\
1 \\
\text { it }\end{array}$ & 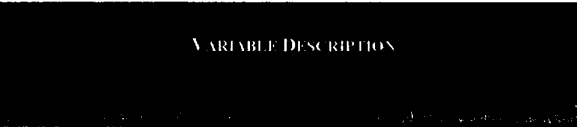 & 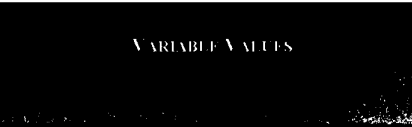 \\
\hline 5 & $40-41$ & Q27M & 2 & $\begin{array}{l}\text { Question 27M. Thinking about driving farm vehicles on } \\
\text { public roads, what kind of things do or have you or your } \\
\text { help ever done to avoid being involved in a farm vehicle } \\
\text { public road crash? }\end{array}$ & $\begin{array}{l}01=\text { Travel when traffic is light } \\
02=\text { Drive slower } \\
03=\text { Not overload } / \text { secure materials } \\
\quad \text { better } \\
04=\text { Stay off main road } \\
05=\text { Be very cautious/pay attention/be } \\
\quad \text { alert } \\
06=\text { Repair secondary roads/maintain } \\
\quad \text { roads better } \\
07=\text { Pulled off/moved off road for } \\
\quad \text { other to pass } \\
08=\text { Safety chains on trailers } \\
09=\text { Don't travel on roads after dark } \\
10=\text { Maintain /inspect vehicle } \\
11=\text { Hired someone else to haul } \\
12=\text { Drive in middle of road to keep } \\
\quad \text { folks from passing }\end{array}$ \\
\hline 5 & 42 & Q28 & 1 & $\begin{array}{l}\text { Question 28. I'm going to read you a few statements. } \\
\text { For each one, I'd like you to tell me if you, "Strongly } \\
\text { agree, agree, disagree, or strongly disagree with it. } \\
\text { Driving farm vehicles on public roads is dangerous }\end{array}$ & $\begin{array}{l}1=\text { Strongly disagree } \\
2=\text { Disagree } \\
3=\text { Agree } \\
4=\text { Strongly Agree } \\
8=\text { No opinion/don't know }\end{array}$ \\
\hline 5 & 43 & Q29 & 1 & $\begin{array}{l}\text { Question 29. I'm going to read you a few statements. } \\
\text { For each one, I'd like you to tell me if you, "Strongly } \\
\text { agree, agree, disagree, or strongly disagree with it. } \\
\text { I feel safe driving farm vehicles on public roads }\end{array}$ & $\begin{array}{l}1=\text { Strongly disagree } \\
2=\text { Disagree } \\
3=\text { Agree } \\
4=\text { Strongly Agree } \\
8=\text { No opinion/don't know }\end{array}$ \\
\hline 5 & 44 & Q30 & 1 & $\begin{array}{l}\text { Question } 30 . \text { I'm going to read you a few statements. } \\
\text { For each one, I'd like you to tell me if you, "Strongly } \\
\text { agree, agree, disagree, or strongly disagree with it. } \\
\text { It is important to feel safe driving farm vehicles on } \\
\text { public roads }\end{array}$ & $\begin{array}{l}1=\text { Strongly disagree } \\
2=\text { Disagree } \\
3=\text { Agree } \\
4=\text { Strongly Agree } \\
8=\text { No opinion/don't know }\end{array}$ \\
\hline 5 & 45 & Q31 & 1 & $\begin{array}{l}\text { Question } 31 . \text { I'm going to read you a few statements. } \\
\text { For each one, I'd like you to tell me if you, "Strongly } \\
\text { agree, agree, disagree, or strongly disagree with it. } \\
\text { Agriculture is a dangerous occupation }\end{array}$ & $\begin{array}{l}1=\text { Strongly disagree } \\
2=\text { Disagree } \\
3=\text { Agree } \\
4=\text { Strongly Agree } \\
8=\text { No opinion/don't know }\end{array}$ \\
\hline 5 & 46 & Q32 & 1 & $\begin{array}{l}\text { Question } 32 \text {. I'm going to read you a few statements. } \\
\text { For each one, I'd like you to tell me if you, "Strongly } \\
\text { agree, agree, disagree, or strongly disagree with it. } \\
\text { I will be farming in five years }\end{array}$ & $\begin{array}{l}1=\text { Strongly disagree } \\
2=\text { Disagree } \\
3=\text { Agree } \\
4=\text { Strongly Agree } \\
8=\text { No opinion/don't know }\end{array}$ \\
\hline 5 & $47-48$ & Q33 & 2 & $\begin{array}{l}\text { Question 33. Since you began working in agriculture, } \\
\text { either as an owner or paid employee, including working } \\
\text { on a family farm, how many crashes have you or your } \\
\text { help had with your farm vehicles on public roads? }\end{array}$ & $\begin{array}{l}\text { Values }=1-15 \text { Crashes } \\
0=\text { No crashes }\end{array}$ \\
\hline 5 & $49-50$ & Q34 & 2 & $\begin{array}{l}\text { Question 34. How many of those crashes you } \\
\text { mentioned happened within the last } 10 \text { years (since } \\
\text { 1992)? }\end{array}$ & $\begin{array}{l}\text { Values }=1-10 \text { Crashes } \\
0=\text { No crashes }\end{array}$ \\
\hline
\end{tabular}




\begin{tabular}{|c|c|c|c|c|c|}
\hline $\begin{array}{l}c \\
1 \\
k \\
1\end{array}$ & $\operatorname{col}(\mathrm{s})$ & I.IRISIBI:L: & $\begin{array}{l}1 \\
\vdots \\
\vdots \\
i \\
i \\
\text { in. }\end{array}$ & 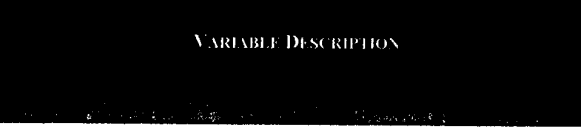 & I MRITHIE TIICLS \\
\hline 5 & $51-52$ & Q35A & 2 & $\begin{array}{l}\text { Question } 35 \mathrm{~A} \text {. In what month did the most recent farm } \\
\text { vehicle crash occur? }\end{array}$ & $\begin{array}{l}01=\text { January } \\
02=\text { February } \\
03=\text { March } \\
04=\text { April } \\
05=\text { May } \\
06=\text { June } \\
07=\text { July } \\
08=\text { August } \\
09=\text { September } \\
10=\text { October } \\
11=\text { November } \\
12=\text { December } \\
\end{array}$ \\
\hline 5 & $53-56$ & Q35B & 4 & $\begin{array}{l}\text { Question 35B. In what year did the most recent farm } \\
\text { vehicle crash occur? }\end{array}$ & Values $=1979-2003$ Year of crash \\
\hline 5 & $57-58$ & Q36 & 2 & Question 36. Who was driving? & $\begin{array}{l}01=\text { Myself } \\
02=\text { Spouse } \\
03=\text { Son }(\text { s)/son-in-law } \\
04=\text { Daughter(s)/daughter(s)-in-law } \\
05=\text { Father/father-in-law } \\
06=\text { Brother(s)/brother(s)-in-law } \\
07=\text { Sister(s)/sister(s)-in-law } \\
08=\text { Cousins, uncles, aunts, nieces, } \\
\text { nephews } \\
09=\text { Friends } \\
10=\text { Non-family hired employee }\end{array}$ \\
\hline 5 & $59-62$ & Q37. & 4 & $\begin{array}{l}\text { Question 37. In what year did you or the person driving } \\
\text { start working in agriculture either as a family member or } \\
\text { paid employee? }\end{array}$ & 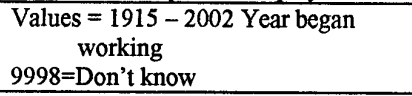 \\
\hline 5 & $63-64$ & Q38 & 2 & $\begin{array}{l}\text { Question 38. How old were you/the person driving at } \\
\text { the time of the crash? }\end{array}$ & $\begin{array}{l}\text { Values }=14-88 \text { Years old } \\
98=\text { Don't know }\end{array}$ \\
\hline 6 & $1-5$ & ID6 & 5 & Identification Number - Card Six & Values $=00010-14762$ \\
\hline 6 & 6 & CARD6 & 1 & Card Number - Card Six & CARD6 always $=6$ \\
\hline 6 & 7 & Q39A1 & 1 & $\begin{array}{l}\text { Question 39A1. Which of your farm vehicles or } \\
\text { equipment were involved? } \\
\text { Tractor }\end{array}$ & $1=$ Yes \\
\hline 6 & $8-11$ & Q39A2 & 4 & $\begin{array}{l}\text { Question 39A2. In what year was the vehicle or } \\
\text { equipment manufactured? }\end{array}$ & $\begin{array}{c}\text { Values }=1944-2001 \text { Year } \\
\text { manufactured }\end{array}$ \\
\hline 6 & 12 & Q39B1 & 1 & $\begin{array}{l}\text { Question 39B1. Which of your farm vehicles or } \\
\text { equipment were involved? } \\
\text { Combine }\end{array}$ & $1=$ Yes \\
\hline 6 & $13-16$ & Q39B2 & 4 & $\begin{array}{l}\text { Question 39B2. In what year was the vehicle or } \\
\text { equipment manufactured? }\end{array}$ & $\begin{array}{c}\text { Values }=1975-2000 \text { Year } \\
\text { manufactured }\end{array}$ \\
\hline 6 & 17 & $\mathrm{Q} 39 \mathrm{Cl}$ & 1 & $\begin{array}{l}\text { Question } 39 \mathrm{Cl} \text {. Which of your farm vehicles or } \\
\text { equipment were involved? } \\
\text { Harvester }\end{array}$ & $1=$ Yes \\
\hline 6 & $18-21$ & Q39C2 & 4 & $\begin{array}{l}\text { Question } 39 \mathrm{C} 2 . \text { In what year was the vehicle or } \\
\text { equipment manufactured? }\end{array}$ & Values $=2000$ Year manufactured \\
\hline 6 & 22 & Q39D1 & 1 & $\begin{array}{l}\text { Question 39D1. Which of your farm vehicles or } \\
\text { equipment were involved? } \\
\text { Attachments }\end{array}$ & $1=$ Yes \\
\hline 6 & $23-26$ & Q39D2 & 4 & $\begin{array}{l}\text { Question 39D2. In what year was the vehicle or } \\
\text { equipment manufactured? }\end{array}$ & $\begin{array}{c}\text { Values }=1950-2002 \text { Year } \\
\text { manufactured }\end{array}$ \\
\hline
\end{tabular}




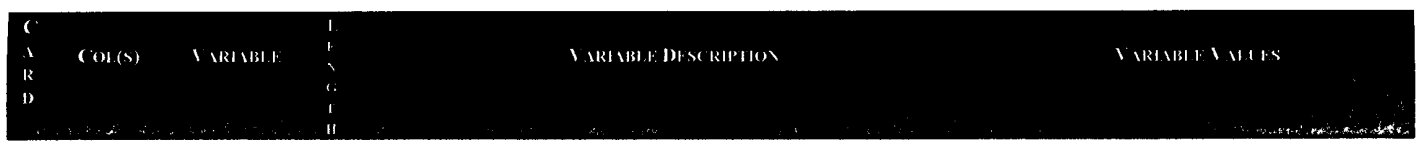

\begin{tabular}{|c|c|c|c|c|c|}
\hline 6 & 27 & Q39E1 & 1 & $\begin{array}{l}\text { Question 39E1. Which of your farm vehicles or } \\
\text { equipment were involved? } \\
\text { Truck }\end{array}$ & $1=$ Yes \\
\hline 6 & $28-31$ & Q39E2 & 4 & $\begin{array}{l}\text { Question 39E2. In what year was the vehicle or } \\
\text { equipment manufactured? }\end{array}$ & $\begin{array}{c}\text { Values }=1971-1999 \text { Year } \\
\text { manufactured }\end{array}$ \\
\hline 6 & $32-33$ & Q39F1 & 2 & $\begin{array}{l}\text { Question } 39 \mathrm{~F} 1 \text {. Which of your farm vehicles or } \\
\text { equipment were involved? } \\
\text { Other vehicle }\end{array}$ & $\begin{array}{l}01=\text { Trailer } \\
02=\text { Front end loader } \\
03=\text { Cattle trailer } \\
04=\text { Hay baler } \\
06=\text { Spreader truck } \\
07=\text { Dump truck }\end{array}$ \\
\hline 6 & $34-37$ & Q39F2 & 4 & $\begin{array}{l}\text { Question 39F2. In what year was the vehicle or } \\
\text { equipment manufactured? }\end{array}$ & $\begin{array}{c}\text { Values }=1970-1997 \text { Year } \\
\text { manufactured }\end{array}$ \\
\hline 6 & 38 & $\overline{\mathrm{Q} 40 \mathrm{~A}}$ & 1 & $\begin{array}{l}\text { Question } 40 \mathrm{~A} \text {. What non-farm vehicles were involved, } \\
\text { for example: car, minivan, SUV? } \\
\text { No non-farm vehicles were involved in the farm } \\
\text { vehicle crash }\end{array}$ & $1=$ Mentioned \\
\hline 6 & 39 & Q40B & 1 & $\begin{array}{l}\text { Question 40B. What non-farm vehicles were involved, } \\
\text { for example: car, minivan, SUV? } \\
\text { Passenger car }\end{array}$ & 1 = Mentioned \\
\hline 6 & 40 & $\mathrm{Q} 40 \mathrm{C}$ & 1 & $\begin{array}{l}\text { Question 40C. What non-farm vehicles were involved, } \\
\text { for example: car, minivan, SUV? } \\
\text { Minivan }\end{array}$ & $1=$ Mentioned \\
\hline 6 & 41 & Q40D & 1 & $\begin{array}{l}\text { Question 40D. What non-farm vehicles were involved, } \\
\text { for example: car, minivan, SUV? } \\
\text { SUV }\end{array}$ & $1=$ Mentioned \\
\hline 6 & 42 & Q40E & 1 & $\begin{array}{l}\text { Question } 40 \mathrm{E} \text {. What non-farm vehicles were involved, } \\
\text { for example: car, minivan, SUV? } \\
\text { Truck }\end{array}$ & $1=$ Mentioned \\
\hline 6 & 43 & Q40F & 1 & $\begin{array}{l}\text { Question } 40 \mathrm{~F} \text {. What non-farm vehicles were involved, } \\
\text { for example: car, minivan, SUV? } \\
\text { Tractor trailer }\end{array}$ & $1=$ Mentioned \\
\hline 6 & $44-45$ & Q40G & 2 & $\begin{array}{l}\text { Question } 4 \mathrm{G} 0 \text {. What non-farm vehicles were involved, } \\
\text { for example: car, minivan, SUV? } \\
\text { Other vehicle }\end{array}$ & $\begin{array}{l}01=\text { Flatbed logging truck } \\
02=\text { Person walked in front of truck } \\
03=\text { Work van } \\
04=\text { Road scrapper } \\
05=\text { No other vehicles involved }\end{array}$ \\
\hline 6 & 46 & Q41A & 1 & $\begin{array}{l}\text { Question 41A. Thinking about driving or transporting } \\
\text { farm vehicles or equipment on public roads, what kinds } \\
\text { of road conditions and driving behaviors contribute to } \\
\text { farm vehicle public road crashes? } \\
\text { Narrow roads/bridges }\end{array}$ & $1=$ Mentioned \\
\hline 6 & 47 & Q41B & 1 & $\begin{array}{l}\text { Question 41B. Thinking about driving or transporting } \\
\text { farm vehicles or equipment on public roads, what kinds } \\
\text { of road conditions and driving behaviors contribute to } \\
\text { farm vehicle public road crashes? } \\
\text { No place to get over to allow vehicles to pass }\end{array}$ & $1=$ Mentioned \\
\hline
\end{tabular}




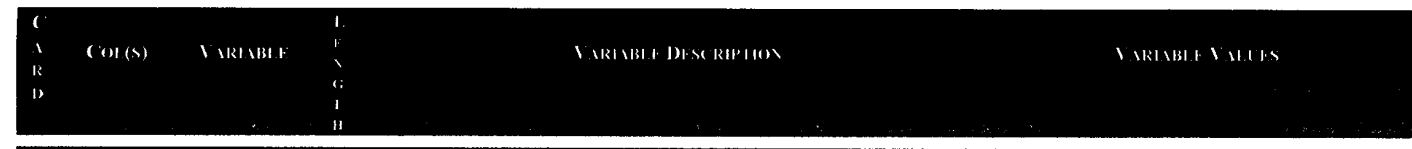

\begin{tabular}{|c|c|c|c|c|c|}
\hline 6 & 48 & $\mathrm{Q} 41 \mathrm{C}$ & 1 & $\begin{array}{l}\text { Question 41C. Thinking about driving or transporting } \\
\text { farm vehicles or equipment on public roads, what kinds } \\
\text { of road conditions and driving behaviors contribute to } \\
\text { farm vehicle public road crashes? } \\
\text { Too much traffic }\end{array}$ & $1=$ Mentioned \\
\hline 6 & 49 & Q41D & 1 & $\begin{array}{l}\text { Question 41D. Thinking about driving or transporting } \\
\text { farm vehicles or equipment on public roads, what kinds } \\
\text { of road conditions and driving behaviors contribute to } \\
\text { farm vehicle public road crashes? } \\
\text { Speeding }\end{array}$ & $1=$ Mentioned \\
\hline 6 & 50 & Q41E & 1 & $\begin{array}{l}\text { Question } 41 \mathrm{E} \text {. Thinking about driving or transporting } \\
\text { farm vehicles or equipment on public roads, what kinds } \\
\text { of road conditions and driving behaviors contribute to } \\
\text { farm vehicle public road crashes? } \\
\text { Poor visibility. }\end{array}$ & $1=$ Mentioned \\
\hline 6 & 51 & $\mathrm{Q} 41 \mathrm{~F}$ & 1 & $\begin{array}{l}\text { Question } 41 \mathrm{~F} \text {. Thinking about driving or transporting } \\
\text { farm vehicles or equipment on public roads, what kinds } \\
\text { of road conditions and driving behaviors contribute to } \\
\text { farm vehicle public road crashes? } \\
\text { Blind curves }\end{array}$ & $1=$ Mentioned \\
\hline 6 & 52 & Q41G & 1 & $\begin{array}{l}\text { Question 41G. Thinking about driving or transporting } \\
\text { farm vehicles or equipment on public roads, what kinds } \\
\text { of road conditions and driving behaviors contribute to } \\
\text { farm vehicle public road crashes? } \\
\text { Dangerous intersections }\end{array}$ & $1=$ Mentioned \\
\hline 6 & 53 & $\overline{Q 41 H}$ & 1 & $\begin{array}{l}\text { Question } 41 \mathrm{H} \text {. Thinking about driving or transporting } \\
\text { farm vehicles or equipment on public roads, what kinds } \\
\text { of road conditions and driving behaviors contribute to } \\
\text { farm vehicle public road crashes? } \\
\text { Inexperienced/young drivers }\end{array}$ & $1=$ Mentioned \\
\hline 6 & 54 & $\overline{Q 41 I}$ & 1 & $\begin{array}{l}\text { Question } 411 \text {. Thinking about driving or transporting } \\
\text { farm vehicles or equipment on public roads, what kinds } \\
\text { of road conditions and driving behaviors contribute to } \\
\text { farm vehicle public road crashes? } \\
\text { No signage }\end{array}$ & $1=$ Mentioned \\
\hline 6 & 55 & $\overline{Q 41 J}$ & 1 & $\begin{array}{l}\text { Question } 41 \mathrm{~J} \text {. Thinking about driving or transporting } \\
\text { farm vehicles or equipment on public roads, what kinds } \\
\text { of road conditions and driving behaviors contribute to } \\
\text { farm vehicle public road crashes? } \\
\text { Lack of non-farm vehicle driver knowledge }\end{array}$ & $1=$ Mentioned \\
\hline 6 & 56 & Q41K & 1 & $\begin{array}{l}\text { Question } 41 \mathrm{~K} \text {. Thinking about driving or transporting } \\
\text { farm vehicles or equipment on public roads, what kinds } \\
\text { of road conditions and driving behaviors contribute to } \\
\text { farm vehicle public road crashes? } \\
\text { No road signs alerting non-farm vehicle drivers to } \\
\text { farm vehicles sharing the road }\end{array}$ & $1=$ Mentioned \\
\hline
\end{tabular}

No road signs alerting non-farm vehicle drivers to

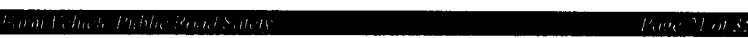




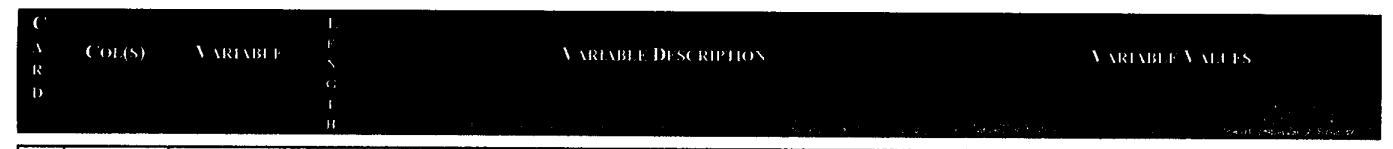

\begin{tabular}{|c|c|c|c|c|c|}
\hline 6 & 57 & Q41L & 1 & $\begin{array}{l}\text { Question } 41 \mathrm{~L} \text {. Thinking about driving or transporting } \\
\text { farm vehicles or equipment on public roads, what kinds } \\
\text { of road conditions and driving behaviors contribute to } \\
\text { farm vehicle public road crashes? } \\
\text { Pot holes }\end{array}$ & $1=$ Mentioned \\
\hline 6 & 58 & Q41M & 1 & $\begin{array}{l}\text { Question 41M. Thinking about driving or transporting } \\
\text { farm vehicles or equipment on public roads, what kinds } \\
\text { of road conditions and driving behaviors contribute to } \\
\text { farm vehicle public road crashes? } \\
\text { Drivers passing when it is not safe }\end{array}$ & $1=$ Mentioned \\
\hline 6 & 59 & Q41N & 1 & $\begin{array}{l}\text { Question } 41 \mathrm{~N} \text {. Thinking about driving or transporting } \\
\text { farm vehicles or equipment on public roads, what kinds } \\
\text { of road conditions and driving behaviors contribute to } \\
\text { farm vehicle public road crashes? } \\
\text { No turn lanes }\end{array}$ & $1=$ Mentioned \\
\hline 6 & 60 & Q410 & 1 & $\begin{array}{l}\text { Question } 410 \text {. Thinking about driving or transporting } \\
\text { farm vehicles or equipment on public roads, what kinds } \\
\text { of road conditions and driving behaviors contribute to } \\
\text { farm vehicle public road crashes? } \\
\text { Drivers don't understand hand signals }\end{array}$ & $1=$ Mentioned \\
\hline 6 & 61 & Q41P & 1 & $\begin{array}{l}\text { Question 41P. Thinking about driving or transporting } \\
\text { farm vehicles or equipment on public roads, what kinds } \\
\text { of road conditions and driving behaviors contribute to } \\
\text { farm vehicle public road crashes? } \\
\text { Impatient drivers }\end{array}$ & $1=$ Mentioned \\
\hline 6 & $62-63$ & Q41Q & 2 & $\begin{array}{l}\text { Question 41Q. Thinking about driving or transporting } \\
\text { farm vehicles or equipment on public roads, what kinds } \\
\text { of road conditions and driving behaviors contribute to } \\
\text { farm vehicle public road crashes? } \\
\text { First other condition }\end{array}$ & $\begin{aligned} & 01=\text { Foreign help who don't know } \\
& \text { traffic rules and regulations } \\
& 02=\text { Not paying careful attention, being } \\
& \quad \text { distracted } \\
& 03=\text { DUI/drugged driver } \\
& 04=\text { Bad weather } \\
& 05=\text { Mailbox too close to road } \\
& 06=\text { No signal lights on equipment } \\
& 07=\text { Brakes failed }\end{aligned}$ \\
\hline 6 & $64-65$ & Q41R & 2 & $\begin{array}{l}\text { Question 4IR. Thinking about driving or transporting } \\
\text { farm vehicles or equipment on public roads, what kinds } \\
\text { of road conditions and driving behaviors contribute to } \\
\text { farm vehicle public road crashes? } \\
\text { Second other condition }\end{array}$ & $\begin{aligned} & 01= \text { Foreign help who don't know } \\
& \text { traffic rules and regulations } \\
& 02= \text { Not paying careful attention, being } \\
& \text { distracted } \\
& 03= \text { DUI/drugged driver } \\
& 04=\text { Bad weather } \\
& 05=\text { Mailbox too close to road } \\
& 06=\text { No signal lights on equipment } \\
& 07=\text { Brakes failed }\end{aligned}$ \\
\hline 6 & 66 & $\mathrm{Q42}$ & 1 & Question 42. Was a police report filed? & $\begin{array}{l}1=\text { Yes } \\
2=\text { No }\end{array}$ \\
\hline 6 & $67-68$ & Q43 & 2 & Question 43. Why not? & $\begin{aligned} 01 & =\text { Damages below reporting } \\
& \text { threshold determined by police } \\
02 & =\text { No insurance } \\
03 & =\text { Minimal damage } \\
04 & =\text { Turned into insurance agent } \\
05 & =\text { No time/too busy }\end{aligned}$ \\
\hline
\end{tabular}




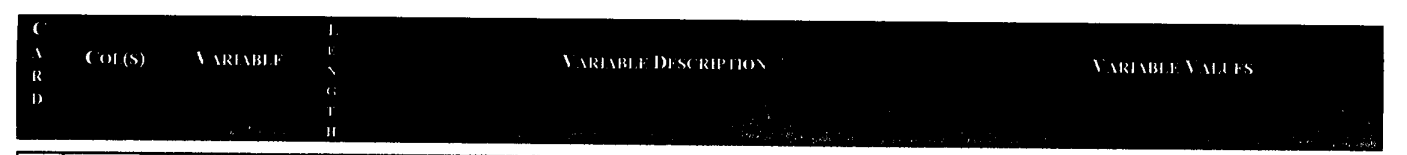

\begin{tabular}{|c|c|c|c|c|c|}
\hline 6 & 69 & Q44 & 1 & Question 44. Was anyone injured in the crash? & $\begin{array}{l}1=\text { Yes } \\
2=\text { No }\end{array}$ \\
\hline 6 & 70 & Q45 & 1 & Question 45. Did anyone die in the crash? & $\begin{array}{l}1=\text { Yes } \\
2=\mathrm{No}\end{array}$ \\
\hline 6 & 71 & Q46 & 1 & $\begin{array}{l}\text { Question 46. Thinking about public road conditions } \\
\text { now and at the time of the crash, would you say public } \\
\text { road conditions now are worse, the same or better than } \\
\text { at the time of the crash? }\end{array}$ & $\begin{array}{l}01=\text { Worse } \\
02=\text { Same } \\
03=\text { Better }\end{array}$ \\
\hline 7 & $1-5$ & ID7 & 5 & Identification Number - Card Seven & Values $=00010-14762$ \\
\hline 7 & 6 & CARD7 & 1 & Card Number - Card Seven & CARD7 always $=7$ \\
\hline 7 & 7 & Q47A & 1 & $\begin{array}{l}\text { Question } 47 \mathrm{~A} \text {. If you could change anything that would } \\
\text { make public roads safer for farmers driving farm } \\
\text { vehicles on public roads, what would you suggest? } \\
\text { Add road signage }\end{array}$ & $1=$ Mentioned \\
\hline 7 & 8 & Q47B & 1 & $\begin{array}{l}\text { Question 47B. If you could change anything that would } \\
\text { make public roads safer for farmers driving farm } \\
\text { vehicles on public roads, what would you suggest? } \\
\text { Educate farmers regarding laws, regulations, etc. }\end{array}$ & $1=$ Mentioned \\
\hline 7 & 9 & Q47C & 1 & $\begin{array}{l}\text { Question } 47 \text { C. If you could change anything that would } \\
\text { make public roads safer for farmers driving farm } \\
\text { vehicles on public roads, what would you suggest? } \\
\text { Educate non-farm vehicle drivers }\end{array}$ & $1=$ Mentioned \\
\hline 7 & 10 & Q47D & 1 & $\begin{array}{l}\text { Question 47D. If you could change anything that would } \\
\text { make public roads safer for farmers driving farm } \\
\text { vehicles on public roads, what would you suggest? } \\
\text { Enforce farm vehicle signage and lighting laws and } \\
\text { regulations }\end{array}$ & $1=$ Mentioned \\
\hline 7 & 11 & $\overline{\mathrm{Q}} 7 \mathrm{E}$ & 1 & $\begin{array}{l}\text { Question } 47 \mathrm{E} \text {. If you could change anything that would } \\
\text { make public roads safer for farmers driving farm } \\
\text { vehicles on public roads, what would you suggest? } \\
\text { Introduce farm licensing laws and enforcement }\end{array}$ & $1=$ Mentioned \\
\hline 7 & 12 & $\mathrm{Q} 47 \mathrm{~F}$ & 1 & $\begin{array}{l}\text { Question } 47 F \text {. If you could change anything that would } \\
\text { make public roads safer for farmers driving farm } \\
\text { vehicles on public roads, what would you suggest? } \\
\text { Enforce speeding laws }\end{array}$ & $1=$ Mentioned \\
\hline 7 & 13 & Q47G & 1 & $\begin{array}{l}\text { Question } 47 \mathrm{G} \text {. If you could change anything that would } \\
\text { make public roads safer for farmers driving farm } \\
\text { vehicles on public roads, what would you suggest? } \\
\text { Enforce unsafe passing laws }\end{array}$ & $1=$ Mentioned \\
\hline 7 & 14 & Q47H & 1 & $\begin{array}{l}\text { Question } 47 \mathrm{H} \text {. If you could change anything that would } \\
\text { make public roads safer for farmers driving farm } \\
\text { vehicles on public roads, what would you suggest? } \\
\text { Have farm vehicles speed time zones like school areas }\end{array}$ & $1=$ Mentioned \\
\hline 7 & 15 & Q47I & 1 & $\begin{array}{l}\text { Question 47I. If you could change anything that would } \\
\text { make public roads safer for farmers driving farm } \\
\text { vehicles on public roads, what would you suggest? } \\
\text { Install flashing lights on all vehicles }\end{array}$ & $1=$ Mentioned \\
\hline
\end{tabular}




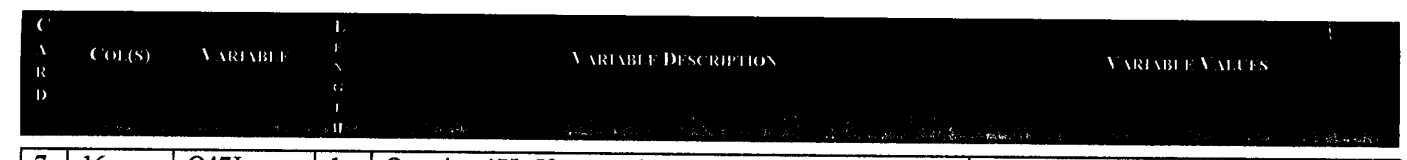

\begin{tabular}{|c|c|c|c|c|c|}
\hline 7 & 16 & Q47J & 1 & $\begin{array}{l}\text { Question } 47 \mathrm{~J} \text {. If you could change anything that would } \\
\text { make public roads safer for farmers driving farm } \\
\text { vehicles on public roads, what would you suggest? } \\
\text { Wider roads/bridges }\end{array}$ & $1=$ Mentioned \\
\hline 7 & 17 & Q47K & 1 & $\begin{array}{l}\text { Question } 47 \mathrm{~K} \text {. If you could change anything that would } \\
\text { make public roads safer for farmers driving farm } \\
\text { vehicles on public roads, what would you suggest? } \\
\text { Shoulder/slow lane for farmers }\end{array}$ & $1=$ Mentioned \\
\hline 7 & $18-19$ & Q47L & 2 & $\begin{array}{l}\text { Question 47L. If you could change anything that would } \\
\text { make public roads safer for farmers driving farm } \\
\text { vehicles on public roads, what would you suggest? } \\
\text { First other suggestion }\end{array}$ & $\begin{array}{c}01=\text { Too much traffic/decrease traffic } \\
\text { volume on roads } \\
02=\begin{array}{c}\text { Don't let newcomers/immigrants } \\
\text { drive on roads (don't know } \\
\text { language or road rules) }\end{array} \\
03=\text { Decrease speed limits } \\
04=\text { Teach about farm vehicles in } \\
\text { drivers education } \\
05=\text { Install signals/signs on equipment } \\
06=\text { Remove mail/paper boxes etc. } \\
\text { from roadside } \\
07=\text { Maintain roads better } \\
08=\text { More warning/alert signs } \\
09=\text { Laws to stop for farmers } \\
10=\text { Don't make farm equipment so } \\
\text { wide } \\
11=\text { Take logging/big trucks off main } \\
\text { roads } \\
12=\text { Drivers need to be more } \\
\text { patient/pay more attention } \\
13=\text { Keep vehicles in working } \\
\text { order/maintain }\end{array}$ \\
\hline 7 & $20-21$ & Q47M & 2 & $\begin{array}{l}\text { Question } 47 \mathrm{M} \text {. If you could change anything that would } \\
\text { make public roads safer for farmers driving farm } \\
\text { vehicles on public roads, what would you suggest? }\end{array}$ & 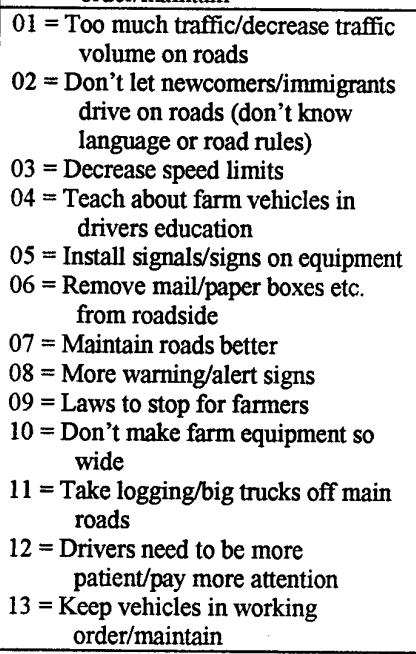 \\
\hline
\end{tabular}




\begin{tabular}{|c|c|c|c|c|c|}
\hline $\begin{array}{ll}3 \\
i \\
k \\
1 \\
1\end{array}$ & $\operatorname{col}(s)$ & 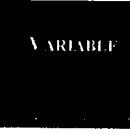 & 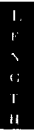 & 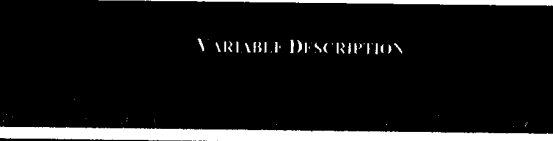 & 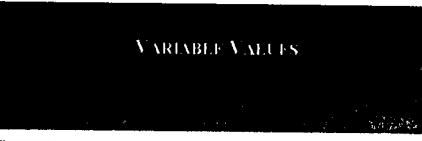 \\
\hline 7 & 22 & $\overline{\mathrm{Q} 48 \mathrm{~A}}$ & 1 & $\begin{array}{l}\text { Question 48A. What crops do you produce? } \\
\text { None }\end{array}$ & $1=$ Mentioned \\
\hline 7 & 23 & Q48B & 1 & $\begin{array}{l}\text { Question 48B. What crops do you produce? } \\
\text { Cotton }\end{array}$ & $1=$ Mentioned \\
\hline 7 & 24 & Q48C & 1 & $\begin{array}{l}\text { Question 48C. What crops do you produce? } \\
\text { Tobacco }\end{array}$ & $1=$ Mentioned \\
\hline 7 & 25 & Q48D & 1 & $\begin{array}{l}\text { Question 48D. What crops do you produce? } \\
\text { Sweet potatoes }\end{array}$ & $1=$ Mentioned \\
\hline 7 & 26 & Q48E & 1 & $\begin{array}{l}\text { Question 48E. What crops do you produce? } \\
\text { Corn }\end{array}$ & $1=$ Mentioned \\
\hline 7 & 27 & $\mathrm{Q} 48 \mathrm{~F}$ & 1 & $\begin{array}{l}\text { Question } 48 \mathrm{~F} \text {. What crops do you produce? } \\
\text { Soy beans }\end{array}$ & $1=$ Mentioned \\
\hline 7 & 28 & Q48G & 1 & $\begin{array}{l}\text { Question 48G. What crops do you produce? } \\
\text { Peppers }\end{array}$ & $1=$ Mentioned \\
\hline 7 & 29 & $\mathrm{Q} 48 \mathrm{H}$ & 1 & $\begin{array}{l}\text { Question } 48 \mathrm{H} \text {. What crops do you produce? } \\
\text { Melons }\end{array}$ & $1=$ Mentioned \\
\hline 7 & 30 & Q48I & 1 & $\begin{array}{l}\text { Question 48I. What crops do you produce? } \\
\text { Berries }\end{array}$ & l = Mentioned \\
\hline 7 & 31 & Q48J & 1 & $\begin{array}{l}\text { Question 48J. What crops do you produce? } \\
\text { Fruit }\end{array}$ & 1 = Mentioned \\
\hline 7 & 32 & $\overline{Q 48 K}$ & 1 & $\begin{array}{l}\text { Question 48K. What crops do you produce? } \\
\text { Grasses/feed grains (e.g, alfalfa, eskew, oats, hay) }\end{array}$ & $1=$ Mentioned \\
\hline 7 & 33 & Q48L & 1 & $\begin{array}{l}\text { Question 48L. What crops do you produce? } \\
\text { Christmas trees }\end{array}$ & $1=$ Mentioned \\
\hline 7 & 34 & Q48M & 1 & $\begin{array}{l}\text { Question } 48 \mathrm{M} \text {. What crops do you produce? } \\
\text { Peanuts }\end{array}$ & 1 = Mentioned \\
\hline 7 & 35 & Q48N & 1 & $\begin{array}{l}\text { Question 48N. What crops do you produce? } \\
\text { Nurseries/greenhouses }\end{array}$ & 1 = Mentioned \\
\hline 7 & 36 & Q48O & 1 & $\begin{array}{l}\text { Question } 480 \text {. What crops do you produce? } \\
\text { Wheat }\end{array}$ & $1=$ Yes \\
\hline 7 & $37-38$ & Q48P & 2 & $\begin{array}{l}\text { Question 48P. What crops do you produce? } \\
\text { Other crop }\end{array}$ & $\begin{aligned} 01 & =\text { Timber } \\
02 & =\text { Assorted vegetables (not listed on } \\
& \text { survey) } \\
03 & =\text { Beans } \\
04 & =\text { Potatoes } \\
05 & =\text { Sod } \\
06 & =\text { Kenaf }\end{aligned}$ \\
\hline 7 & 39 & Q49A & 1 & $\begin{array}{l}\text { Question 49A. What livestock do you raise? } \\
\text { None }\end{array}$ & $1=$ Mentioned \\
\hline
\end{tabular}




\begin{tabular}{|c|c|c|c|c|c|}
\hline $\begin{array}{l}i \\
k \\
1\end{array}$ & $\cos (s)$ & I IRT LBA: & $\begin{array}{c}5 \\
\vdots \\
i \\
i\end{array}$ & 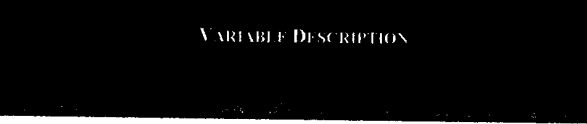 & 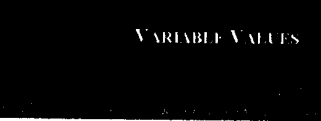 \\
\hline 7 & 40 & Q49B & 1 & $\begin{array}{l}\text { Question 49B. What livestock do you raise? } \\
\text { Poultry }\end{array}$ & $1=$ Mentioned \\
\hline 7 & $\overline{41}$ & Q49C & 1 & $\begin{array}{l}\text { Question 49C. What livestock do you raise? } \\
\text { Turkeys }\end{array}$ & $1=$ Mentioned \\
\hline 7 & 42 & Q49D & 1 & $\begin{array}{l}\text { Question 49D. What livestock do you raise? } \\
\text { Hogs }\end{array}$ & $1=$ Mentioned \\
\hline 7 & 43 & Q49E & 1 & $\begin{array}{l}\text { Question 49E. What livestock do you raise? } \\
\text { Beef cattle }\end{array}$ & $1=$ Mentioned \\
\hline 7 & 44 & Q49F & 1 & $\begin{array}{l}\text { Question 49F. What livestock do you raise? } \\
\text { Dairy cattle }\end{array}$ & $1=$ Mentioned \\
\hline 7 & 45 & Q49G & 1 & $\begin{array}{l}\text { Question 49G. What livestock do you raise? } \\
\text { Horses }\end{array}$ & $1=$ Mentioned \\
\hline 7 & 46 & Q49H & 1 & $\begin{array}{l}\text { Question } 49 \mathrm{H} \text {. What livestock do you raise? } \\
\text { Goats }\end{array}$ & $1=$ Mentioned \\
\hline 7 & $47-48$ & Q49I & 2 & $\begin{array}{l}\text { Question 49I. What livestock do you raise? } \\
\text { Other livestock }\end{array}$ & 01 = Sheep \\
\hline 7 & $49-53$ & $\overline{Q 50}$ & 5 & $\begin{array}{l}\text { Question } 50 \text {. How many acres did you use for farming } \\
\text { and/or livestock in } 2002 \text { ? }\end{array}$ & Values $=1-6700$ Acres \\
\hline 7 & $54-55$ & Q51A & 2 & $\begin{array}{l}\text { Question 51A. In what North Carolina county(ies) do } \\
\text { you farm? }\end{array}$ & $\begin{array}{l}01=\text { Alamance } \\
02=\text { Alexander } \\
03=\text { Alleghany } \\
04=\text { Anson } \\
05=\text { Ashe } \\
06=\text { Avery } \\
07=\text { Beaufort } \\
08=\text { Bertie } \\
09=\text { Bladen } \\
10=\text { Brinswick } \\
11=\text { Buncombe } \\
12=\text { Burke } \\
13=\text { Cabarrus } \\
14=\text { Caldwell } \\
15=\text { Camden } \\
16=\text { Carteret } \\
17=\text { Caswell } \\
18=\text { Catawba } \\
19=\text { Chatham } \\
20=\text { Cherokee } \\
21=\text { Chowan } \\
22=\text { Clay } \\
23=\text { Cleveland } \\
24=\text { Columbus } \\
25=\text { Craven } \\
26=\text { Cumberland } \\
27=\text { Currituck } \\
28=\text { Dare } \\
29=\text { Davidson } \\
30=\text { Davie }\end{array}$ \\
\hline
\end{tabular}




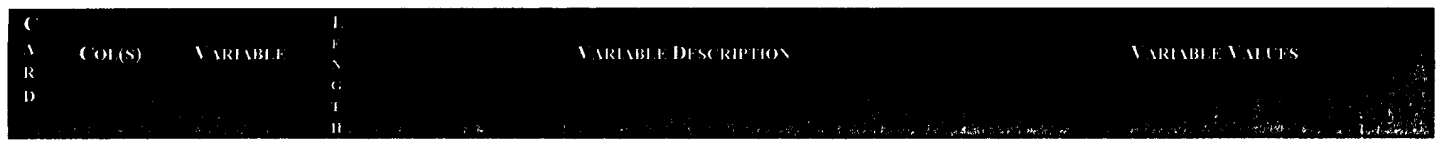

\begin{tabular}{|c|c|c|c|c|c|}
\hline 7 & $54-55$ & Q51A & 2 & $\begin{array}{l}\text { Question 51A. In what North Carolina county(ies) do } \\
\text { you farm? (Continued) }\end{array}$ & $\begin{array}{l}31=\text { Duplin } \\
32=\text { Durham } \\
33=\text { Edgecombe } \\
34=\text { Forsyth } \\
35=\text { Franklin } \\
36=\text { Gaston } \\
37=\text { Gates } \\
38=\text { Graham } \\
39=\text { Granville } \\
40=\text { Greene } \\
41=\text { Guilford } \\
42=\text { Halifax } \\
43=\text { Harnett } \\
44=\text { Haywood } \\
45=\text { Henderson } \\
46=\text { Hertford } \\
47=\text { Hoke } \\
48=\text { Hyde } \\
49=\text { Iredell } \\
50=\text { Jackson } \\
51=\text { Johnston } \\
52=\text { Jones } \\
53=\text { Lee } \\
54=\text { Lenoir } \\
55=\text { Lincoln } \\
56=\text { McDowell } \\
57=\text { Macon } \\
58=\text { Madison } \\
59=\text { Martin } \\
60=\text { Mecklenburg } \\
61=\text { Mitchell } \\
62=\text { Montgomery } \\
63=\text { Moore } \\
64=\text { Nash } \\
65=\text { New Hanover } \\
66=\text { Northampton } \\
67=\text { Onslow } \\
68=\text { Orange } \\
69=\text { Pamlico } \\
70=\text { Pasquotank } \\
71=\text { Pender } \\
72=\text { Perquimans } \\
73=\text { Person } \\
74=\text { Pitt } \\
75=\text { Polk } \\
76=\text { Randolph } \\
77=\text { Richmond } \\
78=\text { Robeson } \\
79=\text { Rockingham } \\
80=\text { Rowan } \\
81=\text { Rutherford } \\
82=\text { Sampson } \\
83=\text { Scotland } \\
84=\text { Stanly } \\
85=\text { Stokes } \\
86=\text { Surry } \\
\end{array}$ \\
\hline
\end{tabular}




\begin{tabular}{|c|c|c|c|c|c|}
\hline $\begin{array}{l}\text { C } \\
i \\
\text { i } \\
11\end{array}$ & (ompts) & I IRI IBI. & : & 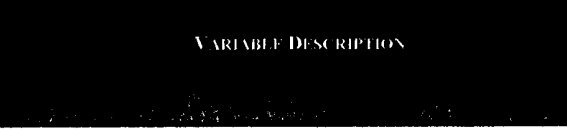 & 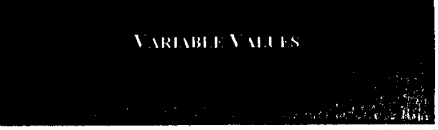 \\
\hline 7 & $54-55$ & $\mathrm{Q} 51 \mathrm{~A}$ & 2 & $\begin{array}{l}\text { Question 51A. In what North Carolina county(ies) do } \\
\text { you farm? (Continued) }\end{array}$ & $\begin{array}{l}87=\text { Swain } \\
88=\text { Transylvania } \\
89=\text { Tyrrell } \\
90=\text { Union } \\
91=\text { Vance } \\
92=\text { Wake } \\
93=\text { Warren } \\
94=\text { Washington } \\
95=\text { Watauga } \\
96=\text { Wayne } \\
97=\text { Wilkes } \\
98=\text { Wilson } \\
99=\text { Yadkin } \\
00=\text { Yancey }\end{array}$ \\
\hline 7 & $56-57$ & Q51B & 2 & $\begin{array}{l}\text { Question 51B. In what North Carolina county(ies) do } \\
\text { you farm? }\end{array}$ & $\begin{array}{l}01=\text { Alamance } \\
02=\text { Alexander } \\
03=\text { Alleghany } \\
04=\text { Anson } \\
05=\text { Ashe } \\
06=\text { Avery } \\
07=\text { Beaufort } \\
08=\text { Bertie } \\
09=\text { Bladen } \\
10=\text { Brunswick } \\
11=\text { Buncombe } \\
12=\text { Burke } \\
13=\text { Cabarrus } \\
14=\text { Caldwell } \\
15=\text { Camden } \\
16=\text { Carteret } \\
17=\text { Caswell } \\
18=\text { Catawba } \\
19=\text { Chatham } \\
20=\text { Cherokee } \\
21=\text { Chowan } \\
22=\text { Clay } \\
23=\text { Cleveland } \\
24=\text { Columbus } \\
25=\text { Craven } \\
26=\text { Cumberland } \\
27=\text { Currituck } \\
28=\text { Dare } \\
29=\text { Davidson } \\
30=\text { Davie } \\
31=\text { Duplin } \\
32=\text { Durham } \\
33=\text { Edgecombe } \\
34=\text { Forsyth } \\
35=\text { Franklin } \\
36=\text { Gaston } \\
37=\text { Gates } \\
38=\text { Graham } \\
39=\text { Granville } \\
40=\text { Greene } \\
41=\text { Guilford } \\
42=\text { Halifax } \\
43=\text { Harnett } \\
\text { a }\end{array}$ \\
\hline
\end{tabular}




\begin{tabular}{|c|c|c|c|c|c|}
\hline $\begin{array}{l}3 \\
1 \\
\text { ik } \\
11\end{array}$ & $\cos (s)$ & I:181 1B1 K & $\begin{array}{l}1 \\
\text { i } \\
\text { in } \\
\text { in }\end{array}$ & 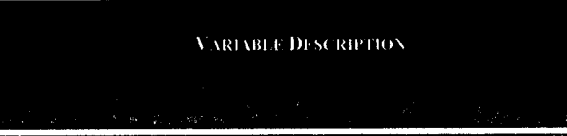 & 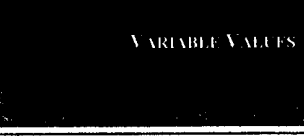 \\
\hline 7 & $56-57$ & Q51B & 2 & $\begin{array}{l}\text { Question } 51 \mathrm{~B} \text {. In what North Carolina county(ies) do } \\
\text { you farm? (Continued) }\end{array}$ & $\begin{array}{l}44=\text { Haywood } \\
45=\text { Henderson } \\
46=\text { Hertford } \\
47=\text { Hoke } \\
48=\text { Hyde } \\
49=\text { Iredell } \\
50=\text { Jackson } \\
51=\text { Johnston } \\
52=\text { Jones } \\
53=\text { Lee } \\
54=\text { Lenoir } \\
55=\text { Lincoln } \\
56=\text { McDowell } \\
57=\text { Macon } \\
58=\text { Madison } \\
59=\text { Martin } \\
60=\text { Mecklenburg } \\
61=\text { Mitchell } \\
62=\text { Montgomery } \\
63=\text { Moore } \\
64=\text { Nash } \\
65=\text { New Hanover } \\
66=\text { Northampton } \\
67=\text { Onslow } \\
68=\text { Orange } \\
69=\text { Pamlico } \\
70=\text { Pasquotank } \\
71=\text { Pender } \\
72=\text { Perquimans } \\
73=\text { Person } \\
74=\text { Pitt } \\
75=\text { Polk } \\
76=\text { Randolph } \\
77=\text { Richmond } \\
78=\text { Robeson } \\
79=\text { Rockingham } \\
80=\text { Rowan } \\
81=\text { Rutherford } \\
82=\text { Sampson } \\
83=\text { Scotland } \\
84=\text { Stanly } \\
85=\text { Stokes } \\
86=\text { Surry } \\
87=\text { Swain } \\
88=\text { Transylvania } \\
89=\text { Tyrrell } \\
90=\text { Union } \\
91=\text { Vance } \\
92=\text { Wake } \\
93=\text { Warren } \\
94=\text { Washington } \\
95=\text { Watauga } \\
96=\text { Wayne } \\
97=\text { Wilkes } \\
98=\text { Wilson } \\
99=\text { Yadkin } \\
00=\text { Yancey } \\
\end{array}$ \\
\hline
\end{tabular}




\begin{tabular}{|c|c|c|c|c|c|}
\hline $\begin{array}{l}\mathbf{c} \\
1 \\
\mathrm{R} \\
1\end{array}$ & $\cos (s)$ & |.1RМบB। & $\begin{array}{l}1 \\
1 \\
\vdots \\
1 \\
1 \\
\text { in }\end{array}$ & 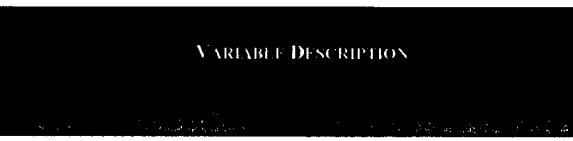 & 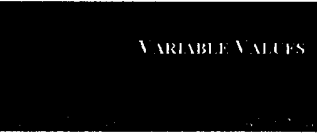 \\
\hline 7 & $58-59$ & Q51C & 2 & $\begin{array}{l}\text { Question 51C. In what North Carolina county(ies) do } \\
\text { you farm? }\end{array}$ & $\begin{array}{l}01=\text { Alamance } \\
02=\text { Alexander } \\
03=\text { Alleghany } \\
04=\text { Anson } \\
05=\text { Ashe } \\
06=\text { Avery } \\
07=\text { Beaufort } \\
08=\text { Bertie } \\
09=\text { Bladen } \\
10=\text { Brunswick } \\
11=\text { Buncombe } \\
12=\text { Burke } \\
13=\text { Cabarrus } \\
14=\text { Caldwell } \\
15=\text { Camden } \\
16=\text { Carteret } \\
17=\text { Caswell } \\
18=\text { Catawba } \\
19=\text { Chatham } \\
20=\text { Cherokee } \\
21=\text { Chowan } \\
22=\text { Clay } \\
23=\text { Cleveland } \\
24=\text { Columbus } \\
25=\text { Craven } \\
26=\text { Cumberland } \\
27=\text { Currituck } \\
28=\text { Dare } \\
29=\text { Davidson } \\
30=\text { Davie } \\
31=\text { Duplin } \\
32=\text { Durham } \\
33=\text { Edgecombe } \\
34=\text { Forsyth } \\
35=\text { Franklin } \\
36=\text { Gaston } \\
37=\text { Gates } \\
38=\text { Graham } \\
39=\text { Granville } \\
40=\text { Greene } \\
41=\text { Guilford } \\
42=\text { Halifax } \\
43=\text { Harnett } \\
44=\text { Haywood } \\
45=\text { Henderson } \\
46=\text { Hertford } \\
47=\text { Hoke } \\
48=\text { Hyde } \\
49=\text { Iredell } \\
50=\text { Jackson } \\
51=\text { Johnston } \\
52=\text { Jones } \\
53=\text { Lee } \\
54=\text { Lenoir } \\
55=\text { Lincoln } \\
56=\text { McDowell } \\
\end{array}$ \\
\hline
\end{tabular}




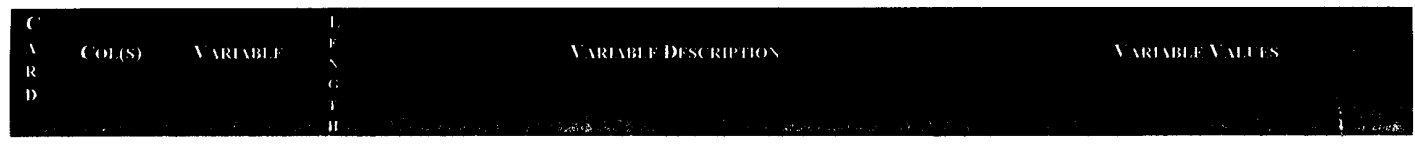

\begin{tabular}{|c|c|c|c|c|c|}
\hline 7 & $58-59$ & Q51C & 2 & $\begin{array}{l}\text { Question 51C. In what North Carolina county(ies) do } \\
\text { you farm? (Continued) }\end{array}$ & 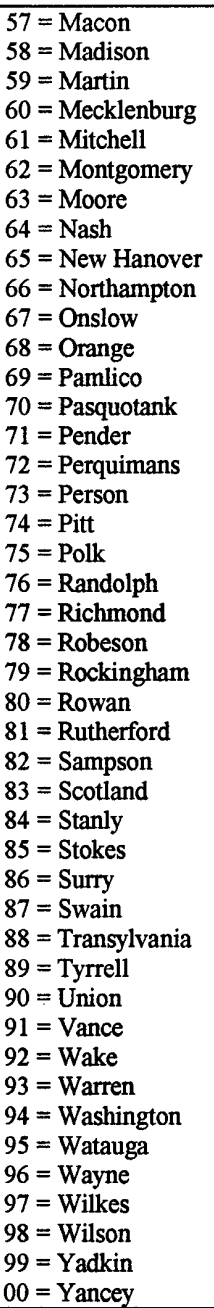 \\
\hline 7 & \begin{tabular}{ll|}
$60-61$ \\
\end{tabular} & Q51D & 2 & $\begin{array}{l}\text { Question 51D. In what North Carolina county(ies) do } \\
\text { you farm? }\end{array}$ & $\begin{array}{l}01=\text { Alamance } \\
02=\text { Alexander } \\
03=\text { Alleghany } \\
04=\text { Anson } \\
05=\text { Ashe } \\
06=\text { Avery } \\
07=\text { Beaufort } \\
08=\text { Bertie } \\
09=\text { Bladen } \\
10=\text { Brunswick } \\
11=\text { Buncombe } \\
12=\text { Burke }\end{array}$ \\
\hline
\end{tabular}




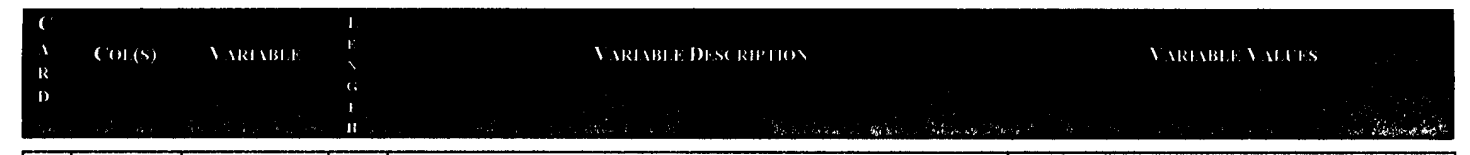

\begin{tabular}{|c|c|c|c|c|c|}
\hline 7 & $60-61$ & Q51D & 2 & $\begin{array}{l}\text { Question 51D. In what North Carolina county(ies) do } \\
\text { you farm? (Continued) }\end{array}$ & $\begin{array}{l}13=\text { Cabarrus } \\
14=\text { Caldwell } \\
15=\text { Camden } \\
16=\text { Carteret } \\
17=\text { Caswell } \\
18=\text { Catawba } \\
19=\text { Chatham } \\
20=\text { Cherokee } \\
21=\text { Chowan } \\
22=\text { Clay } \\
23=\text { Cleveland } \\
24=\text { Columbus } \\
25=\text { Craven } \\
26=\text { Cumberland } \\
27=\text { Currituck } \\
28=\text { Dare } \\
29=\text { Davidson } \\
30=\text { Davie } \\
31=\text { Duplin } \\
32=\text { Durham } \\
33=\text { Edgecombe } \\
34=\text { Forsyth } \\
35=\text { Franklin } \\
36=\text { Gaston } \\
37=\text { Gates } \\
38=\text { Graham } \\
39=\text { Granville } \\
40=\text { Greene } \\
41=\text { Guilford } \\
42=\text { Halifax } \\
43=\text { Harnett } \\
44=\text { Haywood } \\
45=\text { Henderson } \\
46=\text { Hertford } \\
47=\text { Hoke } \\
48=\text { Hyde } \\
49=\text { Iredell } \\
50=\text { Jackson } \\
51=\text { Johnston } \\
52=\text { Jones } \\
53=\text { Lee } \\
54=\text { Lenoir } \\
55=\text { Lincoln } \\
56=\text { McDowe } 11 \\
57=\text { Macon } \\
58=\text { Madison } \\
59=\text { Martin } \\
60=\text { Mecklenburg } \\
61=\text { Mitchell } \\
62=\text { Montgomery } \\
63=\text { Moore } \\
64=\text { Nash } \\
65=\text { New Hanover } \\
66=\text { Northampton } \\
67=\text { Onslow } \\
68=\text { Orange } \\
\end{array}$ \\
\hline
\end{tabular}




\begin{tabular}{|c|c|c|c|c|c|}
\hline $\begin{array}{l}3 \\
i \\
1\end{array}$ & $\operatorname{con}(s)$ & | $181 \backslash 131.1$. & $\begin{array}{l}\text { i: } \\
\vdots \\
\text { iI }\end{array}$ & 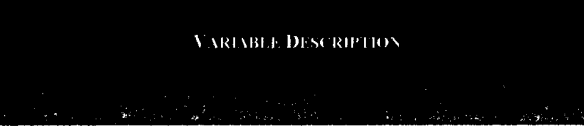 & 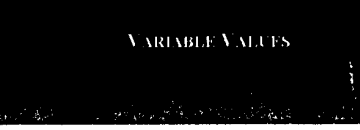 \\
\hline 7 & $60-61$ & Q51D & 2 & $\begin{array}{l}\text { Question 51D. In what North Carolina county(ies) do } \\
\text { you farm? (Continued) }\end{array}$ & $\begin{array}{l}69=\text { Pamlico } \\
70=\text { Pasquotank } \\
71=\text { Pender } \\
72=\text { Perquimans } \\
73=\text { Person } \\
74=\text { Pitt } \\
75=\text { Polk } \\
76=\text { Randolph } \\
77=\text { Richmond } \\
78 \text { = Robeson } \\
79=\text { Rockingham } \\
80=\text { Rowan } \\
81 \text { = Rutherford } \\
82=\text { Sampson } \\
83=\text { Scotland } \\
84=\text { Stanly } \\
85=\text { Stokes } \\
86=\text { Surry } \\
87=\text { Swain } \\
88=\text { Transylvania } \\
89=\text { Tyrrell } \\
90=\text { Union } \\
91=\text { Vance } \\
92=\text { Wake } \\
93=\text { Warren } \\
94=\text { Washington } \\
95=\text { Watauga } \\
96=\text { Wayne } \\
97=\text { Wilkes } \\
98=\text { Wilson } \\
99=\text { Yadkin } \\
00=\text { Yancey }\end{array}$ \\
\hline 7 & $62-63$ & Q52 & 2 & $\begin{array}{l}\text { Question 52. While working in agriculture, how many } \\
\text { times have you been injured badly enough on the job } \\
\text { that you had to miss a day of work or receive medical } \\
\text { treatment? }\end{array}$ & $\begin{array}{l}\text { Values }=1-20 \text { Times } \\
0=\text { No time }\end{array}$ \\
\hline 7 & $64-67$ & $\overline{Q 53}$ & 4 & $\begin{array}{l}\text { Question 53. In what year did you start working in } \\
\text { agriculture either as a family member or paid employee? }\end{array}$ & $\begin{array}{l}\text { Values }=1923-2000 \text { Year started } \\
\text { working }\end{array}$ \\
\hline 7 & $68-69$ & Q54 & 2 & Question 54 . In what year were you born? & Values $=1910-1983$ Birth year \\
\hline 7 & $70-71$ & Q55 & 2 & Question 55. To what racial group do you belong? & $\begin{array}{l}01=\text { White }(\text { Caucasian }) \\
02=\text { Black (African-American) } \\
03=\text { American Indian or Alaskan } \\
\quad \text { Native } \\
04=\text { Asian American } \\
05=\text { Native Hawaiian or Pacific } \\
\quad \text { Islander } \\
99=\text { Refused }\end{array}$ \\
\hline 7 & 72 & Q56 & 1 & $\begin{array}{l}\text { Question } 56 . \text { What is the highest level of education you } \\
\text { have completed? }\end{array}$ & $\begin{array}{l}01=\text { Elementary school } \\
02=\text { Some high school } \\
03=\text { High school graduate } \\
04=\text { Technical/Trade school } \\
05=\text { Some college } \\
06=\text { College graduate } \\
07=\text { Post graduate work }\end{array}$ \\
\hline
\end{tabular}




\begin{tabular}{|c|c|c|c|c|c|}
\hline $\begin{array}{l}\text { i } \\
\text { i } \\
1)\end{array}$ & $\cos (s)$ & 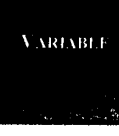 & $\because$ & I IRI.ABI.F DHSTRIPTHS & 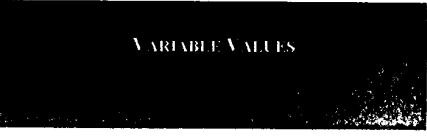 \\
\hline 7 & $73-74$ & Q57 & 2 & $\begin{array}{l}\text { Question } 57 \text {. Over the last five years (e.g. since 1997) } \\
\text { what would you say were your gross farm sales before } \\
\text { taxes for a typical year? Was it ...? }\end{array}$ & $\begin{array}{l}01=\$ 0-\$ 24,999 \\
02=\$ 25,000-\$ 49,999 \\
03=\$ 50,000-\$ 74,999 \\
04=\$ 75,000-\$ 99,999 \\
05=\$ 100,000-\$ 124,999 \\
06=\$ 125,000-\$ 149,999 \\
07=\$ 150,000-\$ 174,999 \\
08=\$ 175,000-\$ 199,999 \\
09=\$ 200,000 \text { or more } \\
99=\text { Refused }\end{array}$ \\
\hline 7 & 75 & Q58 & 1 & Question 58. Respondent's gender. & $\begin{array}{l}1=\text { Male } \\
2=\text { Female }\end{array}$ \\
\hline 7 & $76-77$ & Q59A & 2 & $\begin{array}{l}\text { Question 59A. Is there anything else you would like to } \\
\text { mention regarding farm vehicle public road safety that } \\
\text { you feel would be important for us to understand in } \\
\text { addressing the safety concerns of North Carolina } \\
\text { farmers? }\end{array}$ & 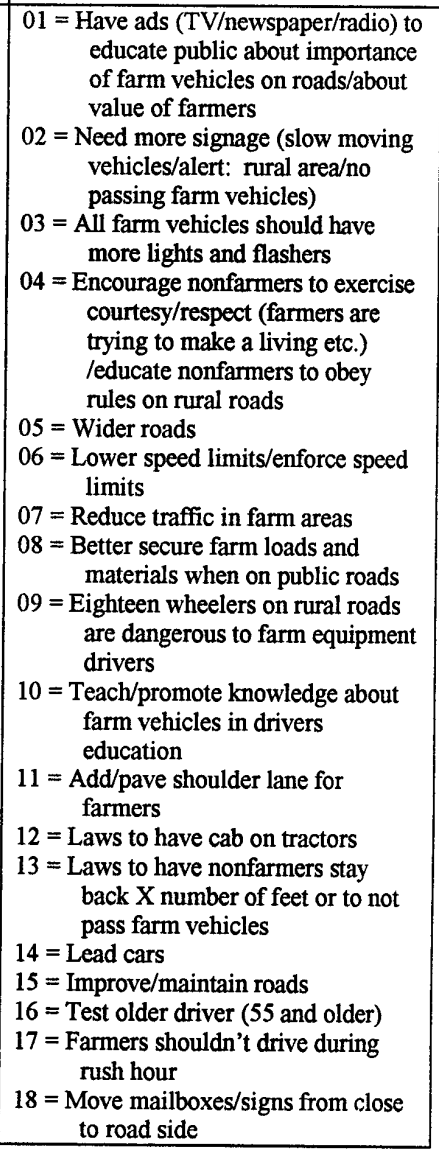 \\
\hline
\end{tabular}




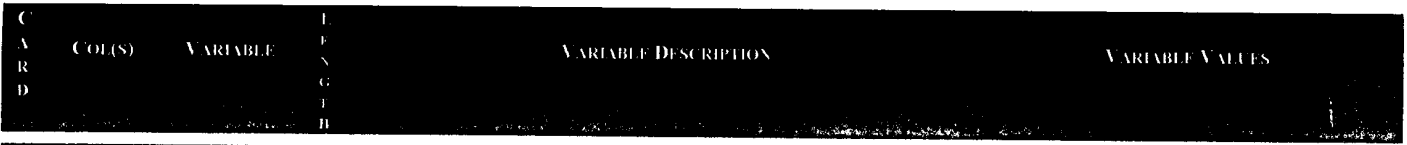

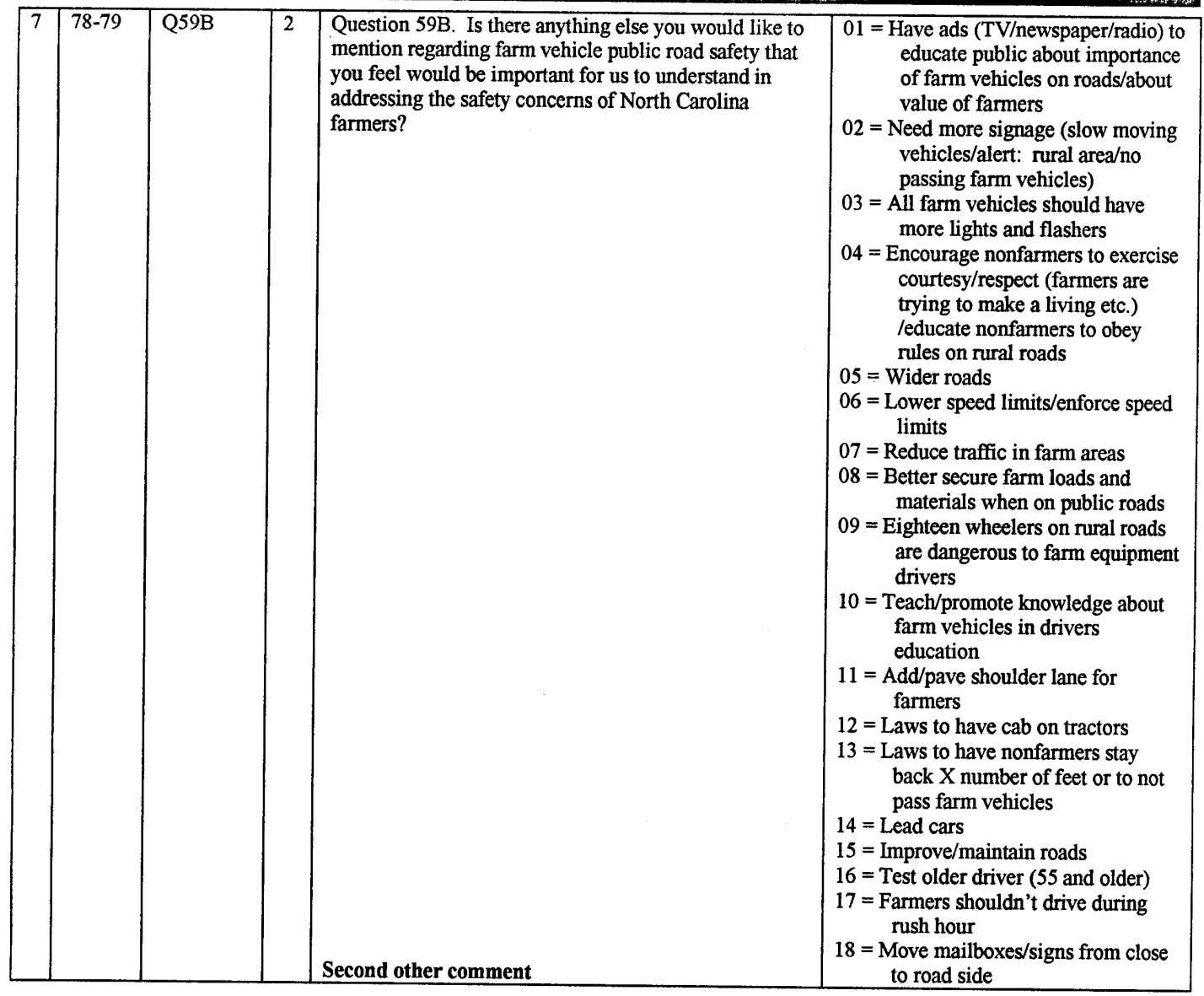

